\title{
Revisión taxonÓmica de ArGythamnia subGénero DitaXis (EUPHORBIACEAE) EN MÉXICO
}

\author{
Yocupitzia Ramírez-Amezcua y yictor Werner Steinmann \\ Instituto de Ecología A.C., Centro Regional del Bajío, Pátzcuaro, Michoacán, México \\ 'Autora para la correspondencia: yocupitzia@yahoo.com
}

\begin{abstract}
Resumen: Se presenta una revisión taxonómica para las especies mexicanas de Argythamnia subgénero Ditaxis (Euphorbiaceae), un taxón neotropical poco estudiado de aproximadamente 50 especies, al que algunos autores tratan como género independiente. En México se registran 14 especies y un taxón infraespecífico, de las cuales siete especies y una variedad son endémicos del país. Argythamnia ingramii y A. silviae se proponen como nuevas para la ciencia y por primera vez se registra a A. simulans en el territorio mexicano. Además, A. micrandra, A. neomexicana y Ditaxis discolor, tres especies reconocidas recientemente se tratan como sinónimos, y se designa lectotipo para A. humilis. Se proporciona una clave para determinación, descripciones morfológicas, información bibliográfica, lista de ejemplares examinados, datos ecológicos, comentarios taxonómicos y mapas de distribución para todos los taxa.
\end{abstract}

Palabras clave: diversidad, especies nuevas, Malpighiales.

\begin{abstract}
A taxonomic revision of the Mexican species of Argythamnia subgen. Ditaxis (Euphorbiaceae) is provided. This subgenus is a little-studied neotropical assemblage of approximately 50 species, considered by some authors to be a genus. Fourteen species and one additional variety occur in Mexico, and seven species and one variety are endemic. Two species, Argythamnia ingramii and $A$. silviae are proposed as new to science and $A$. simulans is reported for the first time from the country. In addition, A. micrandra, A. neomexicana, and Ditaxis discolor, three species that have been recently recognized as distinct are here reduced to synonymy, and a lectotype for A. humilis is designated. A key to the taxa, bibliographic information, morphological descriptions, list of specimens examined, ecological data, taxonomic comments, and distribution maps are given.
\end{abstract}

Kew words: diversity, Malpighiales, new species.

$\boldsymbol{A}$ rgythamnia P.Browne sensu lato (Euphorbiaceae) es un género que incluye unas 88 especies americanas. Entre las características distintivas del grupo destaca el indumento malpigiáceo, un tipo de tricomas escaso en la familia. El conocimiento taxonómico del género es incompleto, aunque hay revisiones taxonómicas para dos de los tres subgéneros que tradicionalmente lo integran: subg. Argythamnia y subg. Chiropetalum (A.Juss.) J.W.Ingram (Ingram, 1967 y 1980b, respectivamente). Las características que sirven para diferenciar los subgéneros pueden apreciarse en el Cuadro 1. Por otra parte, el subgénero Ditaxis (Vahl ex A.Juss.) Croizat, con alrededor de 50 especies, es el sugénero más diverso y el menos estudiado. Su estatus taxonómico ha sido históricamente inconsistente y se ha debatido si debe reconocerse como género independiente (p.ej. Radcliffe-Smith, 2001) o como taxa infragenérico de Argythamnia (p.ej. Ingram, 1980a). Debido a su complejidad taxonómica, varios autores han señalado la necesidad de hacer una revisión taxonómica para resolver la problemática que lo circunda (Ingram, 1970; Webster, 1994; McVaugh, 1995; Steinmann y Felger, 1997). La presente revisión taxonómica resuelve en gran parte dicha problemática, aunque trata solamente las especies mexicanas del subg. Ditaxis.

\section{Materiales y métodos}

Se recopiló la información referente a Argythamnia en revisiones, floras y listados, así como los protólogos de las especies presentes en México. Se consultaron las bases de datos electrónicas de los herbarios GH, TEX, UC y US, además de la de Tropicos (MO); y se realizaron salidas a campo para colectar material fresco y tomar fotografías de algunas especies. Se procesaron las muestras botánicas y los ejemplares herborizados están depositados en IEB con duplicados en 
IBUG, MEXU y NY. En conjunto, se examinaron más de 1,000 ejemplares de herbarios nacionales y extranjeros. Por motivos de espacio, para la mayoría de las especies solamente se cita material examinado representativo, para revisarlo en su totalidad consultar Ramírez-Amezcua (2007). Se cotejaron o establecieron las determinaciones de acuerdo a los tipos y los protólogos, usando un microscopio estereoscópico. Las sinonimias se establecieron de acuerdo con el Código Internacional de Nomenclatura Botánica (Greuter et al., 2002). Además se generaron descripciones homogéneas para todos los taxa y una clave para su determinación; los mapas de distribución están basados en los datos de localización geográfica de los ejemplares examinados.

Historia taxonómica. En 1824, Adrien de Jussieu describió el género Ditaxis Vahl ex A.Juss. (del griego: didymos: doble y taxis: arreglo, haciendo alusión a la disposición de los estambres en dos verticilos), y la única especie entonces conocida: D. fasciculata Vahl ex A.Juss. [Argythamnia fasciculata (Vahl ex A.Juss.) Müll.Arg.]. Ditaxis fue reconocido como género por Zuccarini (1832) cuando describió la primera especie mexicana, D. heterantha Zucc. [Argythamnia heterantha (Zucc.) Müll.Arg.]. Pocos años después, Nuttall (1837) propuso el género Aphora Nutt. para una especie de Estados Unidos de América y luego Bentham (1844) describió el género Serophyton Benth. y la segunda especie del grupo presente en México: Serophyton lanceolatum Benth. [Argythamnia lanceolata (Benth.) Müll.Arg.]. En el año siguiente, Engelmann y Gray (1845) redujeron Serophyton a sinónimo de Aphora e hicieron la combinación Aphora lanceolata (Benth.) Engelm. \& A.Gray, además describieron la tercera especie presente en México, Aphora humilis Engelm. \& A.Gray [Argythamnia humilis (Engelm. \& A.Gray) Müll. Arg.]. Aphora también fue reconocido por Torrey (1858) quien describió Aphora laevis A.Gray ex Torr. [Argythamnia humilis (Engelm. \& A.Gray) Müll. Arg.] y Aphora serrata Torr. [Argythamnia serrata (Torr.) Müll.Arg.].

Müller Argoviensis (1866) publicó la primera revisión de Argythamnia en el Prodromus de de Candolle y propuso una clasificación infragenérica con base en morfología floral, donde las especies de Ditaxis quedaron dentro de Argythamnia en las secciones Ditaxis y Aphora. Distinguió a los miembros de la sección Ditaxis por tener pétalos enteros y glándulas pequeñas, mientras los de Aphora tienen pétalos enteros o subenteros y las glándulas alargadas y angostas.

En los años posteriores al trabajo de Müller, Ditaxis fue, por lo general, considerado como sinónimo de Argythamnia. Por ejemplo, Gray (1870) describió A. adenophora A.Gray, Millspaugh (1889) describió A. brandegeei Millsp., Rose (1895) propuso A. manzanilloana Rose, y Greenman (1898; 1905) describió A. neomexicana var. depressa Greenm. y A. pringlei Greenm.

Hace casi un siglo, Pax y Hoffmann (1912) realizaron la segunda revisión de las especies de Ditaxis y, a diferencia de Müller, lo consideraron como distinto de Argythamnia. Su trabajo es la última revisión completa para Ditaxis, género que dividieron en cinco secciones diferenciadas por caracteres florales y vegetativos: Acaules, Anacanthium, Aphora, Calycanthae y Serophyton. Todas las secciones, excepto Acaules, incluyen especies mexicanas. Sin embargo, aún después del trabajo de Pax y Hoffmann, el estatus taxonómico de Ditaxis siguió inconsistente; por ejemplo, Johnston (1924) reconoció al género Ditaxis cuando describió D. brandegeei var. intonsa, mientras Croizat (1945) hizo el cambio de esta especie a Argythamnia considerando a Ditaxis como subgénero.

Ingram es el taxónomo moderno que más ha trabajado con Argythamnia. Según su concepción, Ditaxis es uno de tres subgéneros de Argythamnia (Chiropetalum y Argythamnia son los otros). En 1956, Ingram presentó una revisión parcial del subgénero Ditaxis como tesis doctoral (no publicada formalmente). Su trabajo se basó en el análisis de la morfología macro y microscópica de 51 especies (de las cuales al menos seis son sinónimos). Con base en sus resultados propuso ocho secciones y distinguió el arreglo del tejido vascular del pecíolo (característico en Argythamnia), mientras las demás estructuras analizadas reflejaron los rasgos típicos del género y la familia. Otros trabajos relevantes de este autor son sobre la circunscripción de A. guatemalensis y A. tinctoria (1964), la revisión para el subg. Argythamnia (Ingram, 1967), un artículo acerca de los límites genéricos de Argythmania (Ingram, 1980a) y la revisión de las especies del subgénero Chiropetalum (Ingram, 1980b).

De las publicaciones recientes acerca de las especies del subg. Ditaxis destacan la de McVaugh (1995), donde presenta una discusión del taxón en Nueva Galicia y el tratamiento para Euphorbiaceae de Sonora (Steinmann y Felger, 1997), que incluye una discusión sobre el complejo A. neomexicana y A. serrata. Dos trabajos acerca de las Euphorbiaceae de México fueron publicados en 2002: Martínez et al. citan 17 especies (ocho endémicas), mientras Steinmann reporta 15 especies (siete endémicas) y un taxa infraespecífico. Otros tratamientos regionales relativamente recientes que incluyen especies de Argythamnia subg. Ditaxis son: Flora of Baja California (Wiggins, 1980), Flora of the Chihuahuan Desert Region (Henrickson y Johnston, 1997) y Flora Fanerogámica del Valle de México (Calderón de Rzedowski, 2001). Por otra parte, se comparten seis especies con Estados Unidos de América (Argythamnia adenophora, A. brandegeei var. intonsa, A. humilis, A. lanceolata, A. serrata y A. simulans) y se tratan en los trabajos de Wheeler (1960), Johnston y Warnock (1962), Webster (1967), Ingram (1970), Martin y Hutchins (1980), McGregor (1986), Diggs et al. (1999) y Turner (2001). Otras dos especies se comparten con Centroamérica: una de ellas [D. guatemalensis (Müll.Arg.) Pax \& K.Hoffm.] se incluye en Flora de Guatemala de Standley y Steyermark (1949), y en Flora Costaricensis de Burger y 
Huft (1995); y la otra [A. serrata (Torr.) Müll.Arg.] representa el primer registro para Guatemala.

Estatus taxonómico. La inconsistencia del estatus taxonómico del subg. Ditaxis se evidencia por las cambiantes acepciones de los autores. Por ejemplo, entre los taxónomos que lo han reconocido a nivel de género destacan: Zuccarini (1832), Heller (1898, 1912), Rose y Standley (1912), Pax y Hoffmann (1912, 1914, 1931), Johnston (1923), Eastwood (1929), Punt (1962), Webster (1994), Steinmann y Felger (1995, 1997), Radcliffe-Smith y Govaerts (1997), Govaerts et al. (2000), Martínez et al. (2002), Steinmann (2002) y Kiesling (2003). $\mathrm{Al}$ igual que Chiropetalum, Ditaxis ha sido incluido como una sección de Argythamnia por Müller $(1865,1866)$ y Bentham (1880) y como subgénero del mismo por Croizat (1945), Ingram (1953, 1956, 1957, 1964, 1967, 1980a, b), Johnston y Warnock (1962) y McVaugh (1995). Además se ha reconocido simplemente dentro de Argythamnia (sin distinción de categoría infragenérica) por Gray (1870), Millspaugh $(1889,1896)$, Greenman $(1898,1905)$, Rose (1895), Brandegee (1906, 1908) y Jepson (1936).

Las más recientes clasificaciones de Euphorbiaceae basadas en morfología (Webster, 1994; Radcliffe-Smith, 2001) reconocen a Ditaxis como un género independiente y miembro de la subfamilia Acalyphoideae, tribu Chrozophoreae, subtribu Ditaxinae. Aunque cabe mencionar que Webster (1994) encontró controversial la delimitación dentro de la subtribu y para su circunscripción se apoyó en la morfología de polen (que constituye un criterio útil para caracterizar géneros, tribus y subfamilias en Euphorbiaceae). Sin embargo, estudios basados en datos moleculares (Ramírez-Amezcua, 2011) muestran que las especies de Ditaxis no forman un grupo monofilético y se anidan dentro Argythamnia, por lo que es pertinente reconocer Argythamnia subg. Ditaxis.

\section{Morfología de Argythamnia subg. Ditaxis}

Hábito.- Hierbas anuales o perennes (Argythamnia serrata), subarbustos (A. guatemalensis, A. lanceolata y A. manzanilloana) y arbustos que a veces se reportan como pequeños árboles (A. pringlei y A. heterantha). Látex ausente. La mayoría son erectas (Figura 1), pero también hay especies postradas (A. serrata en parte).

Corteza.- Generalmente fisurada, grisácea o amarillenta, y ligeramente corchosa en algunas especies.

Indumento.- Formado predominantemente por tricomas malpigiáceos, pero algunas especies también tienen tricomas simples (A. adenophora). Los tricomas malpigiáceos son unicelulares, formados por dos brazos generalmente de igual longitud y a veces, (especialmente en el ovario) una fracción es más larga que la otra (A. serrata). En general, hay tricomas presentes en tallos jóvenes, hojas, sépalos, pétalos y ovarios, y casi siempre están ausentes en las glándulas del disco y el androceo. Dependiendo de su densidad y coloración, dan apariencia plateada o dorada. Se conocen plantas glabras en dos taxa, y en ambos casos han sido reconocidas como especies diferentes: Aphora laevis $(=\mathrm{Ar}$ gythamnia humilis var. laevis) y Argythamnia californica, aunque aquí se tratan como sinónimos de A. humilis y $A$. serrata, respectivamente.

Hojas.- Simples, alternas y simétricas, deciduas o persistentes. En la mayoría de las especies son nanófilas y llegan a ser notófilas en Argythamnia heterantha, A. guatemalensis y A. pringlei. Generalmente pecioladas, con la inserción del pecíolo marginal, rara vez sésiles (A. simulans, A. lanceolata en parte y $A$. serrata en parte). Las formas más frecuentes son ovadas, elípticas y angostamente ovadas, aunque también las hay obovadas y lanceoladas. Venación actinódroma con tres o cinco nervaduras primarias, basales o suprabasales. Márgenes mayormente aserrulados y aserrados, los dientes con el ápice esferulado o papilado, a veces reducidos a un punto glandular (A. serrata en parte). De las especies mexicanas, A. lanceolata casi siempre tiene hojas con margen entero.

Estípulas.- En pares a ambos lados del pecíolo, enteras o

Cuadro 1. Caracteres morfológicos para distinguir los subgéneros de Argythamnia. Nótese que algunos caracteres como los pétalos de las flores estaminadas y el número y arreglo de los estambres muestran un interesante patrón de variación.

\begin{tabular}{|c|c|c|c|}
\hline Carácter & subg. Argythamnia & subg. Chiropetalum & subg. Ditaxis \\
\hline Estambres & $\begin{array}{l}4-5 \text { en un verticilo, o seis y } \\
\text { entonces uno terminal }\end{array}$ & 3-5 en un verticilo & 7-12 en dos verticilos \\
\hline Tricomas & $\begin{array}{l}\text { malpigiáceos y/o simples, } \\
\text { a veces ausentes }\end{array}$ & $\begin{array}{l}\text { estrellados, malpigiáceos } \\
\text { y/o simples, a veces ausentes }\end{array}$ & $\begin{array}{l}\text { malpigiáceos y/o simples, } \\
\text { a veces ausentes }\end{array}$ \\
\hline Estilos & dos a tres veces bífidos & una vez bífidos & una vez bífidos \\
\hline Flores estaminadas & tetrámeras & pentámeras & pentámeras \\
\hline $\begin{array}{l}\text { Pétalos de las } \\
\text { flores estaminadas }\end{array}$ & $\begin{array}{l}\text { irregularmente enteros } \\
\text { o lobados }\end{array}$ & $\begin{array}{l}\text { profundamente divididos } \\
\text { (3-5-7 lobados) }\end{array}$ & $\begin{array}{l}\text { enteros, erosos o laciniados, } \\
\text { rara vez escasamente } 3 \text { lobados }\end{array}$ \\
\hline
\end{tabular}



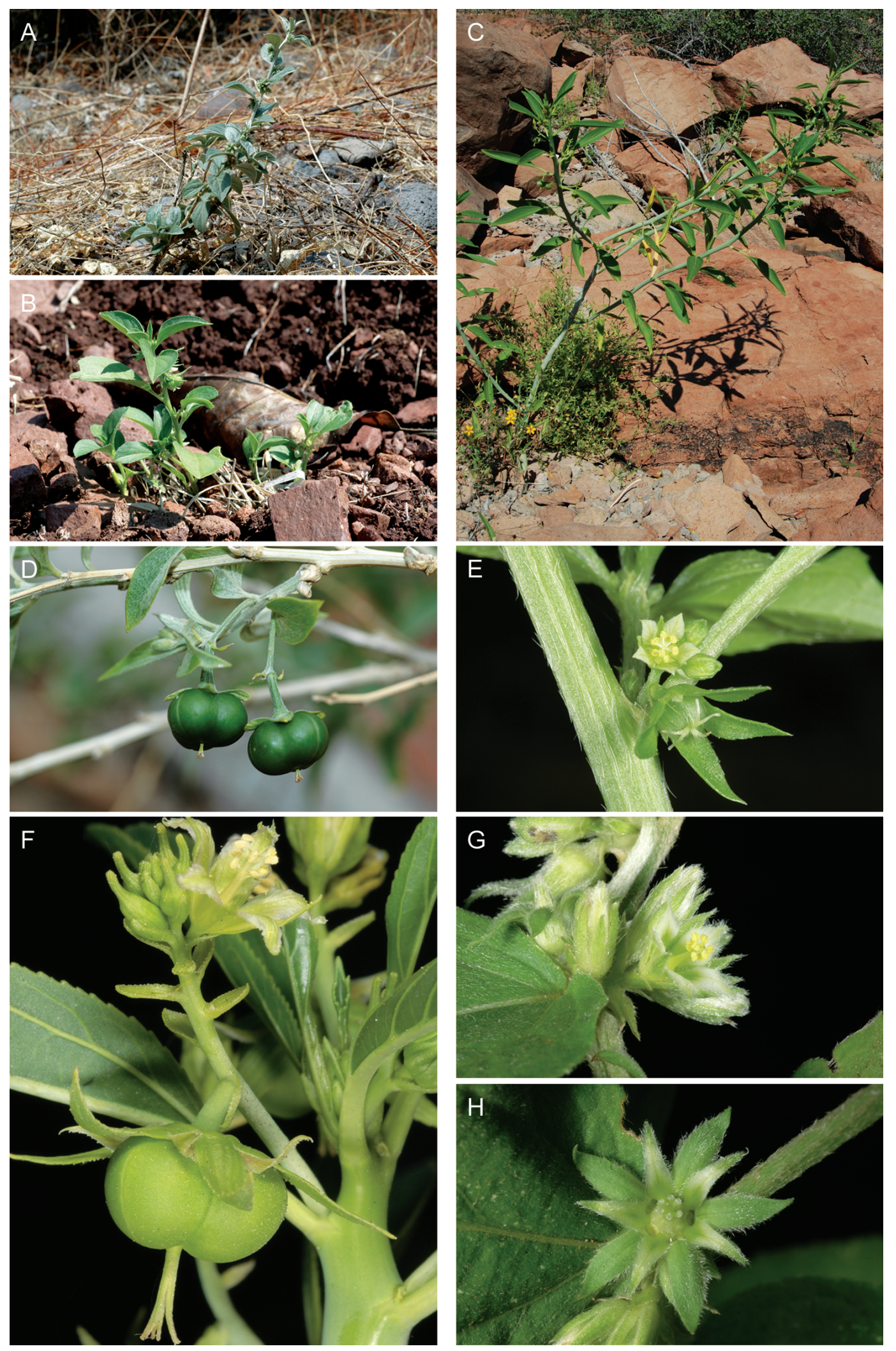

Figura 1. Hábito de A. Argythamnia guatemalensis, B. Argythamnia serrata y C. Argythamnia brandegeei. D. Frutos de Argythamnia heterantha. E, F. Inflorescencia E. Argythamnia serrata, F. Argythamnia brandegeei. G, H. Argythamnia guatemalensis. G. Flor estaminada. H. Flor pistilada. 
rara vez divididas (Argythamnia adenophora), angostamente triangulares, ovadas, elípticas o subuladas, persistentes o caedizas, generalmente pequeñas e inconspicuas, a veces glandulares, frecuentemente presentan tricomas malpigiáceos, al menos en la cara abaxial, pero también las hay glabras, con el margen aserrulado, aserrado, ciliado o fimbriado. Argythamnia arlynniana y A. dressleriana $(=$ A. serrata) se describieron como plantas sin estípulas, pero aunque reducidas o caedizas se encuentran presentes.

Sexualidad.- Monoicas, rara vez dioicas. No se conoce bien el dioicismo en las especies mexicanas, pero Argythamnia arlynniana, una especie poco conocida del norte de México, se considera dioica, mientras A. humilis y A. lanceolata se comportan como dioicas eventualmente. Según O’Donell y Lourteig (1942), algunas especies de Sudamérica como A. dioica y A. malpighiphila son estrictamente dioicas.

Inflorescencia.- Generalmente racimos bisexuales, axilares y cortos. Algunas especies presentan inflorescencias elongadas (Argythamnia brandegeei, A. heterantha, A. pringlei y A. simulans) que llegan a medir hasta $9.5 \mathrm{~cm}$ de largo. Flores sostenidas por brácteas ovadas, elípticas o lanceoladas, pilosas al menos en la cara externa o glabras como en A. arlynniana. Normalmente hay una flor pistilada (rara vez dos) en la base de la inflorescencia y de tres a cinco flores estaminadas hacia la parte distal, pero en las plantas con inflorescencias largas llega a haber hasta 20 flores estaminadas. Las flores pistiladas se desarrollan y maduran antes que las estaminadas (inflorescencias protóginas), por lo que la autopolinización en un mismo racimo resulta imposible. Racimos unisexuales masculinos o bien flores pistiladas solitarias en las axilas de las hojas se presentan en A. arlynniana, A. humilis y A. lanceolata (Figura 1).

Flores estaminadas.- Pentámeras, actinomorfas, sésiles o con pedicelos cortos hasta de $5 \mathrm{~mm}$. Sépalos valvados, libres, ovados, elípticos o lanceolados, mayormente con indumento malpigiáceo o glabros (como en parte de Argythamnia brandegeei, A. humilis y A. serrata). Los pétalos pueden o no estar adnados al andróforo, generalmente enteros o erosos (A. serrata), o laciniados (A. brandegeei). El disco está compuesto por cinco glándulas opuestas a los sépalos, normalmente glabras o rara vez con tricomas simples ( $A$. serrata). Pistilodio ausente. El andróforo sostiene de 7 a 12 estambres dispuestos en dos verticilos casi siempre bien diferenciados. En A. heterantha y A. mercurialina los verticilos son muy cercanos y a veces indistintos. La mayoría de las especies mexicanas tienen diez estambres. En algunas especies las flores estaminadas presentan excrecencias generalmente filiformes en el ápice de la columna estaminal, que se consideran estaminodios, aunque cabe la posibilidad de que sean pistilodios (se requiere un estudio morfológico para determinar su naturaleza). Generalmente los estaminodios son glabros, pero A. ingramii y A. manzanilloana los tienen plumosos. A veces están reducidos a tubérculos pequeños, como en A. guatemalensis, pero pueden incluso ser más largos que los filamentos de los estambres fértiles o conformar claramente un tercer verticilo. En A. ingramii y A. manzanilloana los estaminodios son caracteres constantes que las ayudan a identificarlas, pero en A. pringlei pueden o no estar presentes. Anteras dorsifijas, ditecas, amarillas (Figura 1).

Flores pistiladas.- Pentámeras, actinomorfas y generalmente con un pedicelo de menos de $1 \mathrm{~cm}$. En Argythamnia heterantha y A. pringlei ligeramente engrosados y hasta de $1.5 \mathrm{~cm}$ de largo. Sépalos valvados y separados en la base. Pétalos siempre presentes, aunque a veces rudimentarios ( $A$. heterantha y A. humilis). Estaminodios ausentes. Ovario súpero, tricarpelar, sostenido por un disco con cinco glándulas opuestas a los sépalos, casi siempre glabras, pero pueden tener tricomas simples (A. serrata). Estilos tres, cada uno bífido, generalmente con indumento malpigiáceo. Estigmas aplanados o rollizos (Figura 1).

Fruto y semilla.- Cápsula esquizocárpica trilobada, dehiscente. Cada lóculo contiene una semilla ovoide, esferoidal o triquetro-piramidal y ecarunculada (en las especies mexicanas). La superficie puede ser lisa u ornamentada, ya sea foveolada, alveolada, punteada, reticulada, rugosa, tuberculada, estriada o verrucosa (Figura 1).

\section{Clave para distinguir los subgéneros de Argythamnia}

1. Estambres 7-12, en dos verticilos .................subg. Ditaxis 1. Estambres 3-6, en un verticilo, excepto cuando seis, entonces cinco en un verticilo y uno terminal.

2. Pétalos ligera a profundamente 3 a 5-7 lobados; estilos una vez bífidos, estigmas rollizos; indumento frecuentemente de tricomas estrellados, además de tricomas simples y malpigiáceos; estambres 3-5 en un verticilo...................................................subg. Chiropetalum 2. Pétalos enteros a ligeramente lobados, ocasionalmente 1 o 2 lobados; estilos usualmente dos o tres veces bífidos, estigmas aplanados; indumento de tricomas simples y o malpigiáceos; estambres $4-5$ en un verticilo o 6 y entonces uno terminal .............................subg. Argythamnia

Diversidad y distribución. El subgénero Ditaxis agrupa aproximadamente 50 especies presentes en el trópico y los subtrópicos de América, principalmente en climas áridos, desde el nivel del mar hasta 2,500 m. En México, la mayoría de las especies se encuentran en bosque tropical caducifolio y matorral xerófilo, aunque también las hay en bosque de encino y pino-encino.

Importancia económica. De las especies mexicanas del subg. Ditaxis solamente Argythamnia heterantha (azafranillo o azafrán de bolita), tiene valor comercial (ver discusión de esta especie).

Estado de conservación de las especies. La mayoría de las especies mexicanas están ampliamente distribuidas, y al 
parecer, no tienen problemas de supervivencia, por lo que no se consideran especies amenazadas o en peligro. Solamente cuatro de ellas pudieran estar en riesgo: Argythamnia simulans, que se conoce de una sola colecta mexicana, pero también se encuentra en el estado de Texas, E.U.A., donde es más frecuente, y A. arlynniana, A. depressa y A. silviae, que se conocen únicamente de dos colectas (Coahuila, Puebla-Oaxaca y Oaxaca respectivamente). En estos casos se deberían realizar evaluaciones en campo para determinar si en realidad están riesgo, o si son más comunes que lo que las colectas existentes sugieren.

\section{Tratamiento taxonómico}

Argythamnia P.Browne subg. Ditaxis (Vahl ex A.Juss.) Croizat, J. Arnold Arbor. 26:191. 1945. Ditaxis Vahl ex A.Juss., Euphorb. Gen.: 110. 1824. Argythamnia P.Browne sect. Ditaxis (Vahl ex A.Juss.) Müll. Arg., Linnaea 34:145. 1865. Tipo: Ditaxis fasciculata Vahl ex A. Juss. [= Argythamnia fasciculata (Vahl ex A.Juss.) Müll. Arg., Linnaea 34:146. 1865.]

Aphora Nutt., Trans. Amer. Philos. Soc., n.s., 5:174. 1837. Argythamnia P.Browne sect. Aphora (Nutt.) Müll. Arg., Linnaea 34:147. 1865. Argythamnia P.Browne sect. Aphora (Nutt.) Benth., Gen. Pl. 3:303. 1880. Tipo: Aphora mercurialina Nutt. [= Ditaxis mercurialina (Nutt.) Coult.].

Serophyton Benth., Bot. Voy. Sulphur 52. 1844. Argythamnia P. Browne sect. Serophyton (Benth.) Webster, J. Arn. Arb. 48(3):366. 1967. Tipo: Serophyton lanceolatum Benth. [= Ditaxis lanceolata (Benth.) Pax \& K.Hoffm.]

Hierbas perennes o anuales, postradas o erectas, arbustos y pequeños árboles, monoicos, rara vez dioicos. Látex ausente. Indumento de tricomas malpigiáceos, a veces combinados con tricomas simples, rara vez plantas glabras. Hojas simples, alternas, actinódromas con 3-5 nervios; pecíolo generalmente presente, rara vez sésiles, margen comúnmente aserrado o aserrulado, a veces entero; estípulas persistentes o caedizas, a veces dejando una cicatriz glandular. Inflorescencias racemosas, axilares, bracteadas, bisexuales o unisexuales; cuando bisexuales las flores pistiladas en la base y las estaminadas en la parte superior. Flores estaminadas actinomorfas, con 5 sépalos valvados, libres, 5 pétalos libres, alternos a los sépalos, adnados o no a la columna estaminal, margen entero, eroso o laciniado, 5 glándulas opuestas a los sépalos, estambres (7-)10(-12), connados en una columna y dispuestos en dos verticilos por lo general bien definidos, estaminodios terminales cuando presentes. Flores pistiladas actinomorfas, con 5 sépalos valvados, rara vez imbricados, libres, 5 pétalos, a veces rudimentarios, enteros a erosos, libres, alternos a los sépalos, 5 glándulas opuestas a los sépalos, ovario súpero, tricarpelar, con un óvulo por lóculo, 3 estilos libres o basalmente connados, bífidos, es- tigmas cilíndricos, aplanados o papilosos. Fruto capsular, dehiscente. Semillas esferoidales a ovoides, por lo general ecarunculadas, frecuentemente reticuladas y/o estriadas.

Clave para las especies de Argythamnia subg. Ditaxis en México

1. Glándulas estipitadas presentes en los márgenes de las hojas, estípulas y cáliz de las flores femeninas

A. adenophora

1. Glándulas estipitadas ausentes.

2. Inflorescencias de más de $2.3 \mathrm{~cm}$ de largo.

3. Flores pistiladas con pétalos laciniados o fuertemente erosos; tallos semicarnosos y frecuentemente huecos, marcadamente purpúreos al secarse........... A. brandegeei 3. Flores pistiladas con pétalos enteros o ausentes; tallos leñosos o herbáceos, no semicarnosos ni huecos, verdes o ligeramente purpúreos al secarse.

4. Hojas sésiles; plantas de Coahuila ......... A. simulans 4. Hojas pecioladas; plantas de otros estados de México. 5. Flores pistiladas sobre pedicelos de $1 \mathrm{~mm}$ o menos de largo, con pétalos lineares o angostamente lanceolados bien desarrollados (de 3 a $4.3 \mathrm{~mm}$ ) de largo respecto a los sépalos ............................. guatemalensis 5. Flores pistiladas sobre pedicelos de $1 \mathrm{~mm}$ o más de largo, con pétalos filiformes, espatulados u obovados, muy reducidos (de menos de $2.8 \mathrm{~mm}$ de largo) respecto a los sépalos.

6. Cápsulas con indumento denso A. pringlei

6. Cápsulas glabras o esparcidamente pubescentes A. heterantha

2. Inflorescencias de menos de $2.2 \mathrm{~cm}$ de largo.

7. Estaminodios plumosos.

8. Androceo inserto en la corola (flores en antesis); hojas escasamente aserruladas; plantas con tonos dorados debido al indumento

A. ingramii

8. Androceo exerto de la corola (flores en antesis); hojas conspicuamente aserradas o aserruladas; plantas sin apariencia dorada

A. manzanilloana

7. Estaminodios glabros o ausentes.

9. Flores estaminadas con pétalos reducidos (menos de $1.7 \mathrm{~mm}$ de largo) o ausentes.

10. Estigmas aplanados y dilatados

10. Estigmas rollizos A. humilis 9. Flores estaminadas con pétalos bien desarrollados (más de $1.8 \mathrm{~mm}$ de largo)

11. Plantas dioicas.

12. Arbustos de más de $30 \mathrm{~cm}$ de alto; hojas lanceoladas; estigmas aplanados y fuertemente dilatados; plantas de la Península de Baja California y Sonora.

..A. lanceolata 
12. Hierbas perennes de menos de $30 \mathrm{~cm}$ de alto; hojas lineares o angostamente elípticas; estigmas aplanados pero no dilatados; plantas de Coahuila

A. arlynniana

\section{Plantas monoicas.}

13. Estigmas rollizos.

14. Hierbas perennes postradas.

15. Inflorescencias agregadas densamente hacia la parte apical de las ramas; estilos unidos hasta la mitad de su longitud A. depressa 15. Inflorescencias axilares distribuidas a lo largo del tallo; estilos unidos sólo en la base A. serrata 14. Arbustos y hierbas anuales o perennes, erectos a ascendentes.

16. Flores estaminadas maduras con los pétalos adnados al andróforo, de color azul, púrpura o rosado A. silviae 16. Flores estaminadas maduras con pétalos libres del andróforo, de color amarillento o blanco .. A. serrata

13. Estigmas aplanados.

17. Pétalos de más de $5 \mathrm{~mm}$ de largo, laciniados o fuertemente erosos; tallos semicarnosos, frecuentemente huecos, purpúreos al secarse; cápsula verde-purpúrea al secarse; semillas ovoides a triangulares, de 3 a $4 \mathrm{~mm}$ de largo

A. brandegeei 17. Pétalos de menos de $5 \mathrm{~mm}$ de largo, enteros o ligeramente erosos; tallos leñosos o herbáceos, no semicarnosos ni huecos, verdes al secarse; cápsula verde-grisácea o verde-amarillenta al secarse; semillas globosas a ovoides, de 1.9 a $3.2 \mathrm{~mm}$ de largo.

18. Hojas angostamente lanceoladas o rara vez ovadas, de 1 a $4.5 \mathrm{~cm}$ de largo, de 0.4 a $1.4 \mathrm{~cm}$ de ancho; pétalos elípticos, de 1.8 a 3 mm de largo, de 0.7 a 1.4 $\mathrm{mm}$ de ancho ........ A. lanceolata 18. Hojas elípticas a ovadas, de 1.5 a $11.7 \mathrm{~cm}$ de largo, de 1 a 5 $\mathrm{cm}$ de ancho; pétalos lineares o angostamente lanceolados, de 3 a $4.3 \mathrm{~mm}$ de largo, de 0.5 a $0.6 \mathrm{~mm}$ de ancho A. guatemalensis
Argythamnia adenophora A.Gray, Proc. Amer. Acad. Arts 8:294. 1870. Ditaxis adenophora (A. Gray) Pax \& K.Hoffm. in Engl., Das Pflanzenreich IV. 147. VI [Heft 57]: 65. 1912. Tipo: México, Sonora, Caborca, 1869, E. Palmer 32 (holotipo GH; isotipos LL, NY).

Argythamnia bicolor M.E.Jones, Contr. W. Bot. 15:127. 1929. Tipo: México, Sonora, Hermosillo, 26 oct. 1926, M. E. Jones 22727 [holotipo POM; isotipos MEXU, MO].

Hierba perenne o subarbusto de hasta $1 \mathrm{~m}$ de alto, monoico, tallos erectos a ascendentes, corteza grisácea, ramillas hírtulas a pilosas, con tricomas simples extendidos de dos tamaños distintos. Hojas con estípulas mayormente persistentes, divididas en dos segmentos desiguales, elípticos a ovados, rara vez enteras, de 1 a $8 \mathrm{~mm}$ de largo, margen con glándulas estipitadas, hirsútulas en ambas superficies; pecíolo acanalado, de 0.4 a $1.5 \mathrm{~cm}$ de largo, generalmente las 2/3 partes distales cubiertas con glándulas estipitadas, a veces totalmente cubierto, indumento igual al de las ramillas; lámina elíptica, de 1.5 a $6.5 \mathrm{~cm}$ de largo, de 0.7 a $1.8 \mathrm{~cm}$ de ancho, con 3 nervaduras en la base, escasamente hirsútula en ambos lados, con la pubescencia más densa hacia las nervaduras; base decurrente; ápice agudo a obtuso; margen aserrulado con glándulas estipitadas. Inflorescencias de 0.9 a $1.8 \mathrm{~cm}$ de largo, generalmente con una flor pistilada en la base, rara vez 2 y de 2-6 flores estaminadas en la parte distal; brácteas elípticas o lanceoladas hasta de $7 \mathrm{~mm}$ de largo, hirsútulas; margen con glándulas estipitadas. Flores estaminadas sobre pedicelos hirsútulos de 1.3 a $1.5 \mathrm{~mm}$ de largo; sépalos 5, lanceolados, de 3 a $4 \mathrm{~mm}$ de largo, de 0.4 a $1.2 \mathrm{~mm}$ de ancho, ápice acuminado, margen entero y sin glándulas estipitadas, externamente hirsútulos, internamente glabros; pétalos 5, elípticos a obovados, de 4 a $7 \mathrm{~mm}$ de largo, de 1.4 a $1.8 \mathrm{~mm}$ de ancho, base atenuada, ápice obtuso, adnados a la columna estaminal, de color púrpura o amarillentos con o sin líneas purpúreas, margen aserrulado, externamente con tricomas simples agregados en el centro y hacia la base, internamente glabros; estambres 10, dispuestos en 2 verticilos de 5 cada uno, columna estaminal hasta de $4 \mathrm{~mm}$ de largo, la parte libre del filamento de 2 a $3 \mathrm{~mm}$ de largo, la parte apical de la columna con un tercer verticilo de 3 a 5 estructuras filiformes generalmente recurvadas hacia el ápice, de 0.7 a $1.4 \mathrm{~mm}$ de largo; glándulas ovadas, adnadas a la columna estaminal, de 0.5 a $0.7 \mathrm{~mm}$ de largo, de $0.3 \mathrm{~mm}$ de ancho, glabras, amarillentas, ápice acuminado. Flores pistiladas sobre pedicelos hirsútulos, de 1.3 a 2.7 $\mathrm{mm}$ de largo; sépalos 5, ovados, de 4 a $6.5 \mathrm{~mm}$ de largo, de 1.4 a $2.1 \mathrm{~mm}$ de ancho, ápice agudo, margen aserrulado con glándulas estipitadas, hirsútulos en ambas caras; pétalos 5 , elípticos a angostamente elípticos, de 4 a $6 \mathrm{~mm}$ de largo, de 1.3 a $2.1 \mathrm{~mm}$ de ancho, base atenuada a unguiculada, ápice agudo a obtuso, margen inconspicuamente aserrulado, a veces ligeramente ciliado, externamente con tricomas simples dispersos, agregados hacia el centro, internamente glabros, 
amarillentos o a veces con líneas de color púrpura; ovario hispiduloso, estilos de 1.5 a $2.5 \mathrm{~mm}$ de largo, la porción libre de 0.5 a $1.1 \mathrm{~mm}$ de largo, pilosos, purpúreos; estigmas aplanados, amarillentos; glándulas ovadas, de 0.5 a $1 \mathrm{~mm}$ de largo, de 0.3 a $0.6 \mathrm{~mm}$ de ancho, glabras, purpúreas o verdosas, ápice obtuso. Cápsula de 4 a $4.7 \mathrm{~mm}$ de largo, de 5 a $5.3 \mathrm{~mm}$ de ancho, hispidulosa, con tricomas malpigiáceos de diferente longitud, purpúrea. Semillas ovoides, de 3 a 3.3 $\mathrm{mm}$ de largo, de 2.3 a $2.5 \mathrm{~mm}$ de ancho, base truncada, ápice apiculado, grisáceas, pardas o purpúreas, carúncula ausente, rafe evidente, superficie con ligeras depresiones, a veces inconspicuamente estriadas.

Distribución y ecología: En México se restringe a Sonora y al norte se extiende hasta el suroeste de Arizona en Estados Unidos de América (Figura 2). Crece en bosque espinoso, pastizal y matorral xerófilo en suelos rocosos y volcánicos, desde cerca del nivel del mar hasta $650 \mathrm{~m}$. Se ha colectado con flor $\mathrm{y}$ fruto de enero a marzo y de julio a octubre. Aunque citada para Baja California (Wiggins, 1980), no se ha encontrado ningún ejemplar que corrobore su presencia en esta región.

Argythamnia adenophora es una especie fácilmente reconocible por sus glándulas estipitadas en los márgenes de hojas, estípulas y sépalos femeninos, así como por tener tricomas malpigiáceos solamente en ovarios y cápsulas. Puede confundirse con A. claryana Jeps. (ver especies excluidas y dudosas), una especie que incluso ha sido tratada como sinónimo de A. adenophora, pero fácilmente distinguible por tener tricomas malpigiáceos en toda la planta y glándulas más delgadas sin estípite claramente definido.

Ejemplares adicionales examinados: MÉXICO. SONORA: $3.3 \mathrm{mi} \mathrm{NE}$ of Pozo Coyote and $7.5 \mathrm{mi} \mathrm{NE}$ of El Desemboque San Ignacio, Felger, Flores y Moser 17077-B (ENCB, MEXU); 30 mi S of Benjamin Hill, Fryxell 3078 (ENCB, MICH, NY, TEX); 4 mi E of Navojoa, Gentry 4756 (DS, GH, MEXU, MICH, MO, NY); Caborca, 25 ago. 1884, Pringle s.n. (DS, F, GH, MICH, NY, US); near Hermosillo, Rose, Standley y Russell 12489 (DS, NY, US); 1.5 mi below La Estrella on the Río Yaqui, 19 jul. 1983, Van Devender, Eiber y Schwable s.n. (ENCB); $1 \mathrm{mi}$ W of Colorado, rd to Hermosillo, Wiggins y Rollins 309 (DS, LL, MICH, NY, UC, US); 2 mi NE of San Carlos and $40 \mathrm{mi}$ W of Hermosillo, Wiggins y Rollins 183 (DS, GH, LL, MICH, MO, NY, UC, US).

Argythamnia arlynniana J.W.Ingram, Bull. Torrey Bot. Club 80:420. 1953. Ditaxis arlynniana (J.W.Ingram) Radcl.-Sm. \& Govaerts, Kew Bull. 52:479. 1997. Tipo: México, Coahuila, El Toro, near Morano [probablemente refiere a la ciudad de Movano], jul. 1910, C. A. Purpus 4514 (holotipo $\mathrm{UC}$; isotipo $\mathrm{GH}$ ).

Hierba perenne de hasta $30 \mathrm{~cm}$ de alto, dioica, ramillas con ligeras líneas verticales y cicatrices notorias en los nudos donde se cayeron las hojas, estrigosas. Hojas con estípulas

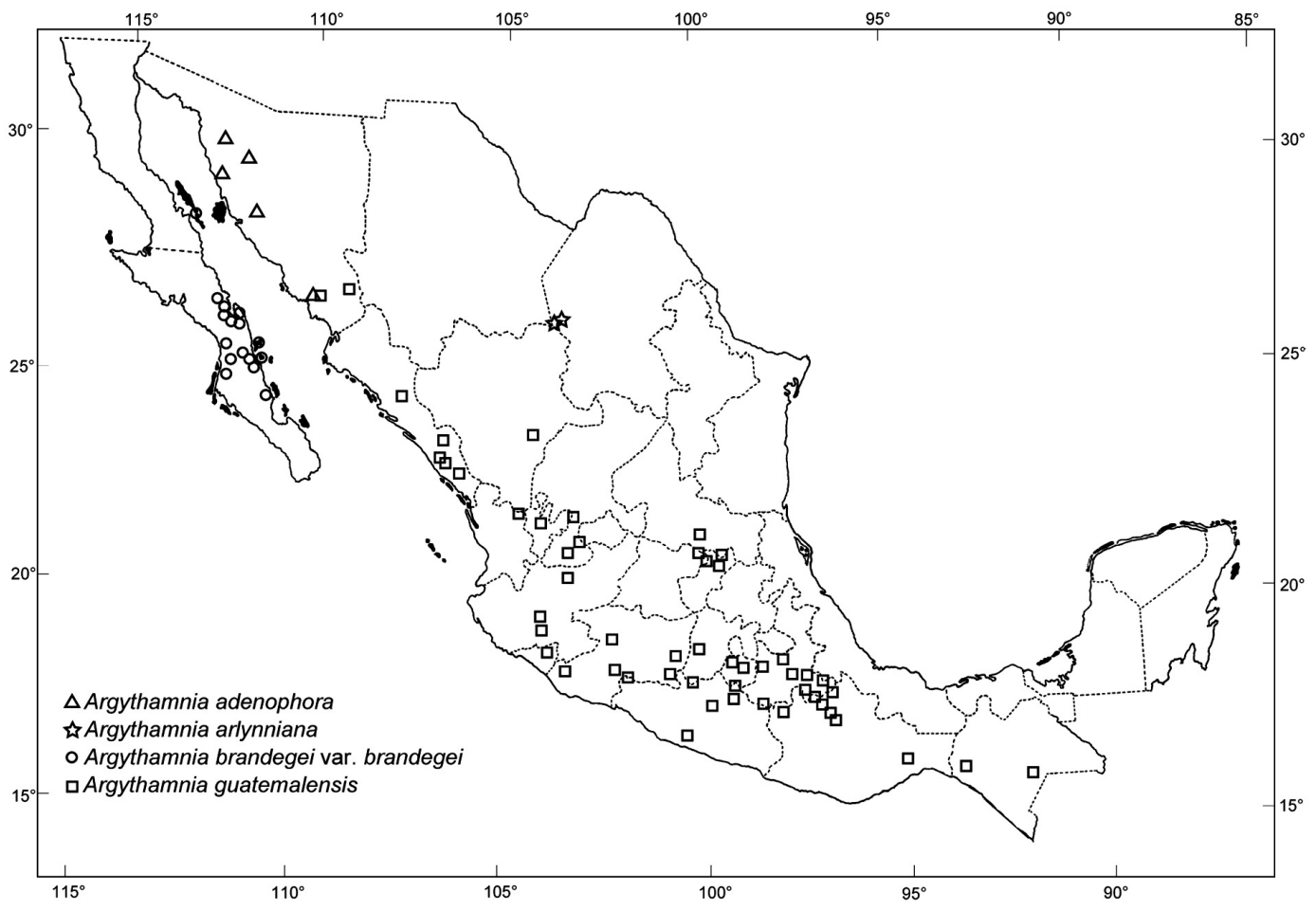

Figura 2. Distribución de Argythamnia adenophora, A. arlynniana, A. brandegeei var. brandegeei y A. guatemalensis. 
deciduas, elípticas, de 0.3 a $1.4 \mathrm{~mm}$ de largo, estrigulosas o glabras, amarillentas, papilosas; pecíolo escasamente distinguible; lámina linear o angostamente elíptica, de 1.1 a 2.4 $\mathrm{cm}$ de largo, de 1.1 a $3.4 \mathrm{~mm}$ de ancho, con 3 nervaduras basales, indumento estriguloso; base aguda; ápice agudo, glandular; margen entero. Inflorescencias de 2 a $6 \mathrm{~mm}$ de largo, flores pistiladas solitarias y de 2 a 4 flores estaminadas; brácteas elípticas a ovadas, de 0.7 a $1.3 \mathrm{~mm}$ de largo, de 0.3 a $0.6 \mathrm{~mm}$ de ancho, amarillentas, a veces verdosas en el centro, las que sostienen flores pistiladas estrigulosas hacia la base, las de las estaminadas glabras;, ápice agudo; margen papiloso. Flores estaminadas sobre pedicelos estrigosos de 0.6 a $1.4 \mathrm{~mm}$ de largo; sépalos 5, lanceolados o angostamente elípticos, de 2.5 a $3.5 \mathrm{~mm}$ de largo, de 0.5 a $0.9 \mathrm{~mm}$ de ancho, ápice agudo y glandular, margen entero; pétalos 5 , elípticos, de 3 a $3.5 \mathrm{~mm}$ de largo, de 0.7 a $1.2 \mathrm{~mm}$ de ancho, base atenuada, ápice agudo, libres de la columna estaminal, purpúreos, margen eroso u ondulado, externamente estrigulosos en la parte media o glabros, internamente glabros; estambres 10 , dispuestos en 2 verticilos de 5 cada uno, columna de 2.3 a $3 \mathrm{~mm}$ de largo, la parte libre del filamento de 0.6 a $0.8 \mathrm{~mm}$ de largo, estaminodios reducidos a una excrecencia apical de $0.1 \mathrm{~mm}$ de largo; glándulas oblongas, oblatas o elípticas, de 0.7 a $0.8 \mathrm{~mm}$ de largo, de 0.3 a $0.4 \mathrm{~mm}$ de ancho, glabras, amarillentas, ápice obtuso, truncado o agudo. Flores pistiladas sobre pedicelos estrigosos de 1 a $3.8 \mathrm{~mm}$ de largo; sépalos 5, angostamente elípticos, de 2.5 a $5.6 \mathrm{~mm}$ de largo, de 0.6 a $2.3 \mathrm{~mm}$ de ancho, base atenuada, ápice agudo, margen hialino, entero, eroso, papiloso o aserrulado con dientes glandulares, externamente estrigulosos, internamente glabros o estrigulosos hacia el ápice y glabrescentes hacia la base; pétalos 5, elípticos, de 1.8 a $3.3 \mathrm{~mm}$ de largo, de 0.8 a $1.2 \mathrm{~mm}$ de ancho, base atenuada, ápice agudo o pilífero, margen eroso o entero, externamente estrigulosos o glabros, internamente glabros, blanquecinos; ovario estrigoso-hispiduloso con tricomas simples y malpigiáceos, estilos con un mechón de tricomas al centro o glabros, purpúreos, de 1.3 a $2.2 \mathrm{~mm}$ de largo, libres de $1.1 \mathrm{a} 1.3 \mathrm{~mm}$; estigmas ligeramente aplanados, amarillentos; glándulas elípticas, de 0.4 a $1 \mathrm{~mm}$ de largo, de 0.5 a $0.7 \mathrm{~mm}$ de ancho, glabras, amarillentas, ápice obtuso. Cápsulas de 2.5 a $4.3 \mathrm{~mm}$ de largo, de 3 a $4.2 \mathrm{~mm}$ de ancho, estrigoso-hispidulosas, purpúreas. Semillas ovoides, de 2.7 a $3 \mathrm{~mm}$ de largo, de 2.2 a $2.4 \mathrm{~mm}$ de ancho, base truncada, ápice apiculado, pardas, carúncula ausente, rafe evidente, superficie ligeramente reticulada, porosa o punteada.

Distribución y ecología: Endémica de México, se conoce solamente de Coahuila (Figura 2). Crece en laderas con suelos arenosos, probablemente entre 1,000 y 1,400 m. Se ha colectado con flor y fruto en julio.

Se conocen pocas colectas de Argythamnia arlynniana y es difícil establecer sus diferencias con A. humilis. Sin embargo, se caracteriza por ser dioica, tener flores pistiladas con pétalos desarrollados (de 1.8 a $3.3 \mathrm{~mm}$ de largo) y hojas lineares a angostamente elípticas (de $1.1 \mathrm{a} 3.4 \mathrm{~mm}$ de ancho); en contraste, A. humilis es monoica (rara vez dioica), tiene los pétalos de las flores pistiladas reducidos (de 0.3 a $1.7 \mathrm{~mm}$ de largo) y las hojas son elípticas u obovadas, rara vez lineares ( 0.2 a $1.6 \mathrm{~cm}$ de ancho).

Ejemplar adicional examinado: MÉXICO. COAHUILA: 9 km E of San José (near Laguna del Rey), Stewart 2648 (GH, TEX).

Argythamnia brandegeei Millsp., Proc. Calif. Acad. Sci., II, 2:220. 1889. Ditaxis brandegeei (Millsp.) Rose \& Standl., Contr. U. S. Natl. Herb. 16:13. 1912.

Hierba perenne o arbusto de hasta $1 \mathrm{~m}$ de alto, monoico, ampliamente ramificado, tallos y ramillas glabros o con tricomas malpigiáceos dispersos, semicarnosos, frecuentemente huecos, purpúreos. Hojas con estípulas diminutas e inconspicuas, deciduas o persistentes, subuladas, de 0.4 a $0.6 \mathrm{~mm}$ de largo, ápice glandular; pecíolo acanalado, de 0.7 a $1.8 \mathrm{~cm}$ de largo; lámina angostamente elíptica, de 4.5 a 9.6 $\mathrm{cm}$ de largo, de 0.9 a $2.9 \mathrm{~cm}$ de ancho, con tres nervaduras en la base, glabra o estrigulosa; base atenuada; ápice agudo o apiculado, rara vez obtuso; margen aserrado. Inflorescencias de 1.5 a $5.5 \mathrm{~cm}$ de largo, con una flor pistilada hacia la base y de 5 a 20 flores estaminadas en la parte distal; brácteas elípticas a ovadas, de 1.5 a $2.2 \mathrm{~mm}$ de largo, glabras, ápice agudo, rara vez obtuso; margen aserrulado. Flores estaminadas sobre pedicelos glabros, de 1 a $1.9 \mathrm{~mm}$ de largo; sépalos 5, lanceolados, de 4 a $6 \mathrm{~mm}$ de largo, de 0.8 a $1 \mathrm{~mm}$ de ancho, ápice agudo, margen entero a ondulado, glabros en ambas caras, a veces escasamente estrigulosos en la cara externa; pétalos 5, elípticos, de 5 a $7 \mathrm{~mm}$ de largo y de 1.2 a $2.5 \mathrm{~mm}$ de ancho, base recta, ápice acuminado, adnados a la columna estaminal, rosados, purpúreos o amarillentos con líneas purpúreas, margen laciniado, glabros en ambas caras o escasamente estrigulosos en la cara externa, con los tricomas agregados hacia el centro; estambres 10, dispuestos en 2 verticilos de 5 cada uno, columna de 3.5 a $4.6 \mathrm{~mm}$ de largo, la parte libre del filamento de 0.4 a $0.6 \mathrm{~mm}$ de largo, estaminodios ausentes o cuando presentes, de 1 a 3 en el ápice de la columna, éstos de 0.1 a $0.2 \mathrm{~mm}$ de largo; glándulas ovadas o elípticas, de 0.5 a $0.7 \mathrm{~mm}$ de largo, de 0.3 a $0.5 \mathrm{~mm}$ de ancho, glabras, amarillentas a purpúreas. Flores pistiladas sobre pedicelos glabros de 1.9 a $5 \mathrm{~mm}$ de largo; sépalos 5, lanceolados, de 5.5 a $9 \mathrm{~mm}$ de largo, de 1.5 a $2.5 \mathrm{~mm}$ de ancho, ápice agudo, margen aserrulado, dientes con la punta glandular, glabros en ambas caras o escasamente estrigulosos; pétalos 5, elípticos, lanceolados o romboides, de 5 a $6 \mathrm{~mm}$ de largo, de 1.5 a $1.6 \mathrm{~mm}$ de ancho, base atenuada, ápice agudo, margen laciniado a eroso, glabros en ambas caras, a veces escasamente estrigulosos externa- 
mente, amarillentos o con líneas de color púrpura; ovario glabro, glabrescente o hispiduloso, estilos de 2.4 a $4 \mathrm{~mm}$ de largo, libres en 1 a $2.5 \mathrm{~mm}$, purpúreos; estigmas aplanados, amarillentos; glándulas oblatas, libres de la columna en el ápice, de 0.7 a $1 \mathrm{~mm}$ de largo, de 0.9 a $1.3 \mathrm{~mm}$ de ancho, glabras, blanquecinas, ápice obtuso. Cápsula globosa, trilobada o a veces tetralobada, de 4.5 a $7 \mathrm{~mm}$ de largo, de 8 a $11 \mathrm{~mm}$ de ancho, glabra, glabrescente o hispidulosa, purpúrea. Semillas ovoides, a veces ligeramente triangulares transversalmente, de 3 a $4 \mathrm{~mm}$ de largo, de 3 a $3.3 \mathrm{~mm}$ de ancho, base truncada, ápice apiculado, grisáceas o pardas, carúncula ausente, rafe evidente, superficie rugosa o lisa. Número cromosómico: $\mathrm{N}=13$ (Webster, 1967).

Se distinguen dos variedades dentro de Argythamnia brandegeei. La variedad típica ha sido concebida como una planta totalmente glabra; sin embargo, se han observado individuos con escasos y delgados tricomas malpigiáceos en las cápsulas. Incluso el isotipo depositado en UC presenta algunos tricomas diminutos e inconspicuos. Por otra parte, la variedad intonsa está conformada por plantas con indumento en el follaje y cápsulas hispidulosas.

Clave para las variedades de Argythamnia brandegeei 1. Cápsulas glabras o esencialmente glabras var. brandegeei 1. Cápsulas hispidulosas. var. intonsa

Argythamnia brandegeei Millsp. Proc. Calif. Acad. Sci., II, 2:220. 1889. var. brandegeei. Ditaxis brandegeei (Millsp.) Rose \& Standl., Contr. U. S. Natl. Herb. 16:13. 1912. Tipo: México, Baja California Sur, San Gregorio, 01 feb. 1889, T. S. Brandegee s.n. (holotipo F; isotipo UC).

Sebastiania sarmentosa M.E.Jones, Contr. W. Bot. 18:49. 1933. Tipo: México, Baja California Sur, Primiera Agua, near Loreto, 19 oct. 1930, M. E. Jones 27544 (sintipo POM; isosintipos MO, US), and near Loreto, 15 oct. 1930, M. E. Jones 27545 [sintipo POM (no visto); isosintipo US (no visto)].

Distribución y ecología: Endémica de México, crece en Baja California y Baja California Sur (Figura 2) en bosque espinoso, dunas costeras y matorral xerófilo, en suelos pedregosos y arenosos, desde el nivel del mar hasta $300 \mathrm{~m}$. Florece y frutifica durante todo el año.

Material adicional examinado: MÉXICO. BAJA CALIFORNIA: Isla Ángel de la Guarda, laguna, Johnston 3402 (CAS, GH, NY, UC, US). BAJA CALIFORNIA SUR: 1.5 $\mathrm{km}$ W of Rosarito, (NE of Canipolé), Carter, Alexander y Kellog 2101 (MEXU, UC, US); Arroyo La Purísima, $11 \mathrm{mi}$ above La Purísima, Constance 3151 (DS, GH, LL, MEXU, UC, US); $18 \mathrm{mi}$ al SO de Santa Rosalía, Gander 9610 (CAS); San Marcos island, Johnston 3628 (CAS, GH, NY,
UC, US); Isla San Marcos, Tenorio et al. 11874 (FCME, IEB, MEXU, MO); Mpio. Constitución, 26 km al N de Loreto, Webster 31418 (TEX); river $37 \mathrm{mi} \mathrm{E}$ of main road on way to San Javier, near rancho Agua Escondida, Wiggins y Ernst 531 (MEXU, UC); $10 \mathrm{mi}$ al S de Mision Dolores, Wiggins, Carter y Ernst 331 (MEXU, MICH, UC); Santispaquis, Wiggins y Wiggins 17980 (DS, MEXU).

Argythamnia brandegeei Millsp. var. intonsa (I.M.Johnst.) J.W.Ingram in L. D. Benson \& Darrow, Trees and Shrubs of Southwestern Deserts, p. 394. 1954. Ditaxis brandegeei (Millsp.) Rose \& Standl. var. intonsa I.M.Johnst., Proc. Calif. Acad. Sci. ser. IV, 12: 1062. 1924. Tipo: México, Baja California Sur, Isla Coronados, 18 may. 1921, I. M. Johnston 3764 (holotipo CAS).

Distribución y ecología: En México se encuentra en Baja California Sur y Sonora (Figura 3), y en Arizona, E.U.A. Crece en matorral xerófilo, en suelos pedregosos, desde el nivel del mar hasta $500 \mathrm{~m}$. Florece y fructifica durante casi todo el año.

Ejemplares adicionales examinados: MÉXICO. BAJA CALIFORNIA SUR: Mpio. Loreto, Rancho Teombó, Arroyo Incha, Sierra de La Giganta, SW of Loreto, Carter y Kellog 3268 (GH, MEXU, MICH, UC); Mpio. La Paz, El Aguajito, arroyo Las Ánimas, Sierra El Mechudo, Domínguez 1747 (IEB); San Nicolás Bay, Johnston 3733 (CAS, GH); Carmen Island, Palmer 809 pro parte (F, NY). SONORA: Mpio. San Luis Río Colorado, sierra de las Tenajas Altas, (60 mi al W de Sonoita), Breedlove 1448 (TEX); Pinacate Region, N side of Los Vidrios on MEX hwy. 2, ca $0.5 \mathrm{~km} \mathrm{~S}$ of hwy, Felger y Cross 18066 (MEXU).

Argythamnia depressa (Greenm.) J.W.Ingram, Bull. Torrey Bot. Club 80:423. 1953. Argythamnia neomexicana Müll. Arg. var. depressa Greenm., Proc. Amer. Acad. Arts 33:478. 1898. Ditaxis depressa (Greenm.) Pax \& K.Hoffm. En: Engl., Das Pflanzenreich IV. 147. VI [Heft 57]: 71. 1912. Tipo: México, Puebla, Tehuacán, 5,000ft (1,524 m), 29 jul. 1897, C. G. Pringle 6752 (holotipo GH, isotipos MEXU, MO, NY, UC).

Hierba perenne postrada, monoica, tallos de hasta $20 \mathrm{~cm}$ de largo, estrigulosos, corteza fisurada, amarillenta, ramillas con ligeras líneas verticales, estrigosas o seríceas. Hojas con estípulas persistentes, elípticas a subuladas, de 0.4 a 1.1 $\mathrm{mm}$ de largo, estrigosas; pecíolo corto, de 1.5 a $3 \mathrm{~mm}$ de largo, indumento igual al de las ramillas; lámina elíptica, de 1.4 a $4.2 \mathrm{~cm}$ de largo, de 4.5 a $8.4 \mathrm{~mm}$ de ancho, verde o purpúrea, con 3 nervaduras suprabasales, estrigulosa en ambas caras; base decurrente; ápice agudo; margen aserrulado o entero, los dientes papilados. Inflorescencias mayormente agregadas en la parte distal de las ramillas, de 6 a $8 \mathrm{~mm}$ de 
largo, cada una con una flor pistilada en la base y de 2 a 3 flores estaminadas en la parte distal; brácteas elípticas, de 0.4 a $1.1 \mathrm{~mm}$ de largo, de 0.5 a $1.5 \mathrm{~mm}$ de ancho; margen eroso o entero. Flores estaminadas sobre pedicelos estrigosos o estrigulosos de 0.6 a $1.1 \mathrm{~mm}$ de largo; sépalos 5 , lanceolados, de 2.5 a $3.7 \mathrm{~mm}$ de largo, de 0.5 a $0.6 \mathrm{~mm}$ de ancho, ápice agudo, margen entero, externamente estrigosos o estrigulosos, internamente glabros; pétalos 5, elípticos, de 2.5 a $4.5 \mathrm{~mm}$ de largo, de 0.9 a $1.3 \mathrm{~mm}$ de ancho, base atenuada, ápice agudo, libres de la columna estaminal, amarillentos, margen entero, externamente estrigulosos, internamente glabros; estambres 10, dispuestos en 2 verticilos de 5 cada uno, columna estaminal de 2 a $2.3 \mathrm{~mm}$ de largo, la parte libre del filamento de 0.3 a $0.4 \mathrm{~mm}$ de largo, estaminodios de 3 a 5 , de 0.1 a $0.2 \mathrm{~mm}$ de largo; glándulas subuladas o filiformes, libres de la columna, de 0.8 a $1.1 \mathrm{~mm}$ de largo y de 0.1 a $0.2 \mathrm{~mm}$ de ancho, glabras, amarillentas. Flores pistiladas sobre pedicelos estrigosos o estrigulosos de 1 a $2.2 \mathrm{~mm}$ de largo; sépalos 5, lanceolados a angostamente elípticos, de 2.5 a $5.2 \mathrm{~mm}$ de largo, de 0.6 a $1.6 \mathrm{~mm}$ de ancho, ápice agudo, frecuentemente con una línea amarillenta en la parte media, margen aserrulado, hialino o amarillento, externamente estrigulosos, internamente glabros; pétalos 5, elípticos, de 1 a $1.7 \mathrm{~mm}$ de largo, de 0.9 a $1.1 \mathrm{~mm} \mathrm{de}$ ancho, base clavada o atenuada, ápice agudo, margen eroso a fimbriado, externamente estrigulosos con los tricomas agregados en el centro, internamente glabros, amarillentos o blancos; ovario estrigoso o hispiduloso, estilos de 1.2 a
$2.3 \mathrm{~mm}$ de largo, libres de 1 a $1.2 \mathrm{~mm}$, con un mechón de tricomas al centro, amarillentos o purpúreos; estigmas teretes, amarillentos; glándulas ovadas, de 0.4 a $0.6 \mathrm{~mm}$ de largo, de 0.4 a $0.5 \mathrm{~mm}$ de ancho, glabras, amarillentas, ápice truncado, obtuso, a veces agudo o emarginado. Cápsula de 2.4 a $3 \mathrm{~mm}$ de largo, de 2.5 a $4.1 \mathrm{~mm}$ de ancho, estrigosa o hispidulosa, verde amarillenta. Semillas ovoide-triangulares, de 1.9 a 2.4 $\mathrm{mm}$ de largo, de 1.6 a $2 \mathrm{~mm}$ de ancho, base truncada, ápice apiculado, grisáceas, carúncula ausente, rafe ligeramente evidente, superficie porosa y ligeramente tuberculada.

Distribución y ecología: Endémica de México, se conocen dos colectas de Puebla: en terrenos planos calcáreos a 1,540 $\mathrm{m}$ y en vegetación secundaria de bosque tropical caducifolio con suelo rojizo a $829 \mathrm{~m}$ (Figura 3). Se ha colectado con flor $\mathrm{y}$ fruto en julio.

Ejemplar adicional examinado: MÉXICO. OAXACA. Distr. Teotitlán de Flores Magón. Mpio. San Antonio Nanahuatipa, río Calapa, al S de San Antonio Nanahuatipa, Tenorio 20396 (IEB).

Argythamnia depressa es una planta rara del valle de Tehuacán-Cuicatlán; se conoce solamente de dos colectas y desafortunadamente no se tiene información ambiental ni de abundancia. Es morfológicamente cercana a A. serrata y se caracteriza por tener inflorescencias densas en la parte distal de las ramas, además de inflorescencias axilares y los estilos

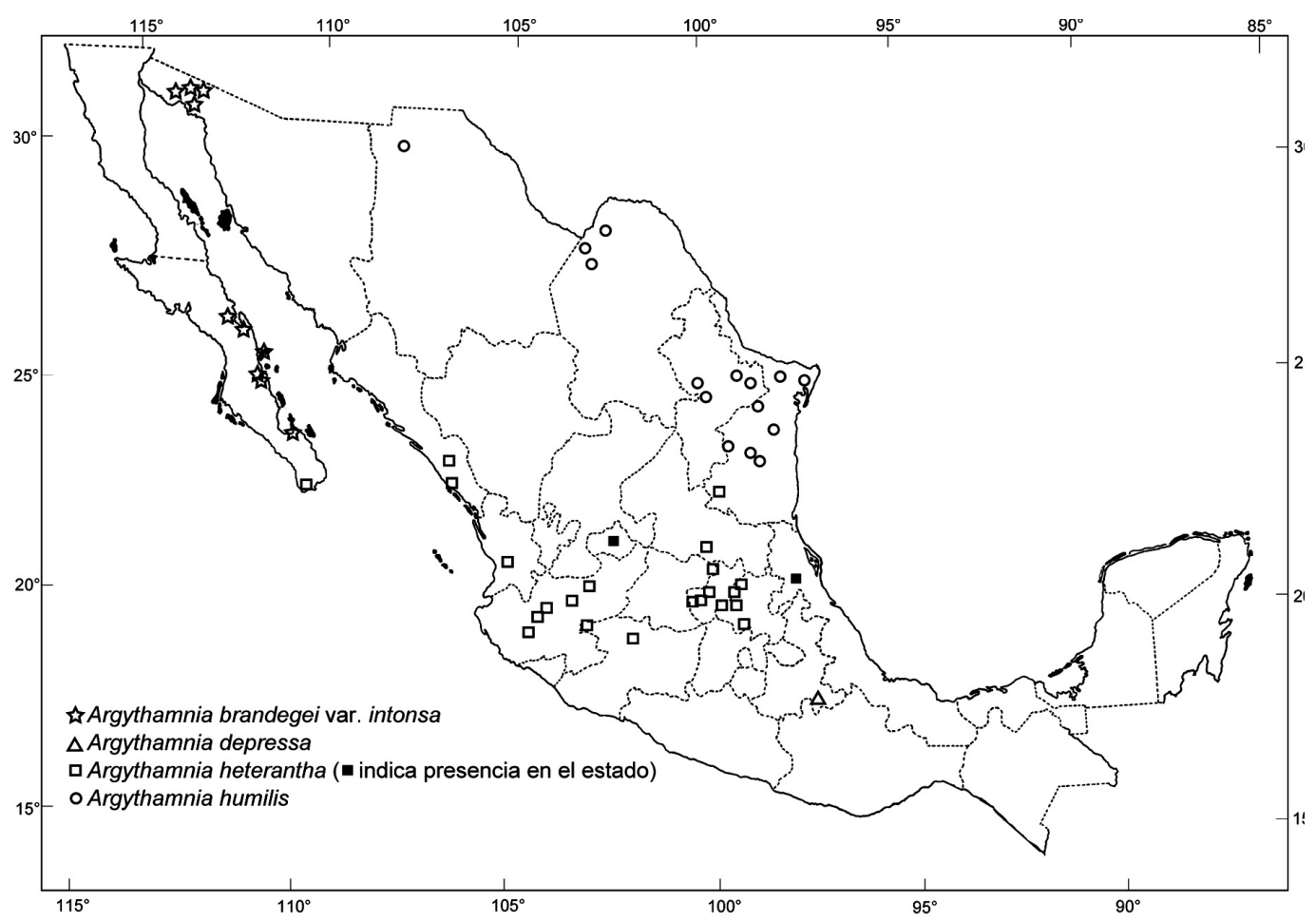

Figura 3. Distribución de Argythamnia brandegeei var. intonsa, A. depressa, A. heterantha y A. humilis. 
unidos en la mitad de su longitud. En contraste, A. serrata tiene inflorescencias racemosas axilares laxas y estilos unidos solamente en la base.

Argythamnia guatemalensis Müll.Arg., Linnaea 34:145. 1865. Ditaxis guatemalensis (Müll. Arg.) Pax \& K.Hoffm. in Engl., Das Pflanzenreich IV. 147. VI [Heft 57]: 59. 1912. Tipo: México, Puebla, Tehuacán, 1841, F. M. Liebmann 5717 (lectotipo C, designado por Ingram, 1964, foto; isolectotipo C, foto).

Ditaxis discolor Brandegee, Zoe 5: 242. 1908. Ditaxis guatemalensis (Müll.Arg.) Pax \& K.Hoffm. var. discolor (Brandegee) Pax \& K.Hoffm. in Engl., Das Pflanzenreich IV. 147. VII [Heft 63]: 426. 1914. Tipo: México, Sinaloa, Culiacán, 1904, T. S. Brandegee s.n. (holotipo UC).

Ditaxis sinaloae I.M.Johnst., Contr. Gray Herb. 68:86(-87). 1923. Tipo: México, Sinaloa, Culiacán, 1891, E. Palmer 1462 (holotipo GH).

Argythamnia guatemalensis Müll.Arg. var. barrancana McVaugh, Contr. Univ. Michigan Herb. 20:190. 1995. Ditaxis guatemalensis (Müll.Arg.) Pax \& K.Hoffm. var. barrancana (McVaugh) Radcl.-Sm. \& Govaerts, Kew Bull. 52:479. 1997. Tipo: México, Zacatecas, S of Jalpa, 1,500 m, 9 sept. 1967, $R$. McVaugh 23801 (holotipo MICH; isotipo IEB).

Hierba perenne o arbusto hasta de $2 \mathrm{~m}$ de alto, monoico, tallos erectos a ascendentes, estrigulosos, corteza blanquecina, corchosa hacia la base, ramillas con ligeras líneas verticales, estrigosas a estrigulosas, los tricomas plateados o dorados. Hojas con estípulas inconspicuas, generalmente persistentes, lanceoladas a ovadas, de 0.5 a $2 \mathrm{~mm}$ de largo, estrigosas, margen entero; pecíolo acanalado, de 2 a $6 \mathrm{~mm}$ de largo, indumento igual al de las ramillas; lámina elíptica a ovada, de 1.5 a $11.7 \mathrm{~cm}$ de largo, de 1 a $5 \mathrm{~cm}$ de ancho, con 3 nervaduras en la base, envés seríceo, lanuloso o estrigoso, haz seríceo, estrigoso, estriguloso, pilosuloso o glabrescente, frecuentemente la pubescencia agregada en las nervaduras; base atenuada, obtusa, cuneada o redondeada; ápice agudo a obtuso, rara vez retuso; margen aserrado, aserrulado o a veces aparentemente entero, con los dientes reducidos a una excrecencia esferoidal no específicamente glandular. Inflorescencias de 0.5 a $2.3 \mathrm{~cm}$ de largo, con una flor pistilada en la base, rara vez 2, y de 3 a 13 flores estaminadas en la parte distal; brácteas ovadas, elípticas, lanceoladas o atenuadas, de 1.7 a $4 \mathrm{~mm}$ de largo, de 0.5 a $1.5 \mathrm{~mm}$ de ancho, externamente lanulosa, serícea o estrigosa, por lo general internamente estrigosa, pilosulosa o glabrescente; margen aserrulado, entero o subentero, con los dientes reducidos como en las hojas. Flores estaminadas sobre pedicelos seríceos o estrigosos de 0.3 a $0.5 \mathrm{~mm}$ de largo; sépalos 5 , lanceolados o angostamente elípticos, de 3.5 a $6 \mathrm{~mm}$ de largo, de 0.7 a $1.1 \mathrm{~mm}$ de ancho, ápice agudo, margen entero, externamente seríceos, estrigosos o lanulosos, internamente pilosulosos, glabrescentes o glabros, con los tricomas agregados en el centro; pétalos 5, angostamente elípticos o lanceolados, de 3 a $6 \mathrm{~mm}$ de largo, de 0.7 a $1.6 \mathrm{~mm}$ de ancho, base atenuada, ápice agudo a atenuado, adnados a la columna estaminal, amarillentos, frecuentemente pardos en la parte media, margen entero, externamente seríceos, estrigosos o lanulosos, internamente pilosulosos, glabrescentes o glabros, con los tricomas agregados hacia la parte media, estambres 10 , dispuestos en 2 verticilos de 5 cada uno, columna estaminal de 1 a $2.6 \mathrm{~mm}$ de largo, la parte libre del filamento de 0.2 a $0.4 \mathrm{~mm}$ de largo, estaminodios presentes, muy reducidos o ausentes, de 3 a 5 , de 0.1 a $0.2 \mathrm{~mm}$ de largo; glándulas ovadas, a veces ligeramente convexas, de 0.4 a $0.9 \mathrm{~mm}$ de largo, de 0.3 a $0.6 \mathrm{~mm}$ de ancho, glabras, amarillentas, blanquecinas o pardas, ápice agudo. Flores pistiladas sobre pedicelos seríceos o estrigosos de 0.3 a 1 $\mathrm{mm}$ de largo, sépalos 5, lanceolados a angostamente elípticos, de 5 a $13 \mathrm{~mm}$ de largo, de 1 a $2.2 \mathrm{~mm}$ de ancho, ápice agudo, margen aserrulado o entero, externamente seríceos, pilosulosos o estrigosos, internamente seríceos, lanulosos o estrigosos; pétalos 5, lineares o angostamente lanceolados, de 3 a $4.3 \mathrm{~mm}$ de largo, de 0.5 a $0.6 \mathrm{~mm}$ de ancho, base recta o ligeramente atenuada, ápice agudo, amarillentos, a veces pardos hacia el centro, margen entero, externamente seríceos, lanulosos o estrigosos, internamente glabros, glabrescentes o pilosulosos, con los tricomas agregados hacia el centro; ovario seríceo, estrigoso o lanuloso, estilos pilosos, de 1.2 a $2.3 \mathrm{~mm}$ de largo, libres de 0.7 a $1.3 \mathrm{~mm}$, purpúreos; estigmas aplanados, pardos o amarillentos; glándulas elípticas a oblatas, de 0.2 a $0.5 \mathrm{~mm}$ de largo, de 0.5 a $0.8 \mathrm{~mm}$ de ancho, glabras, amarillentas, ápice generalmente obtuso, a veces agudo o emarginado, margen entero, a veces ondulado. Cápsula de 2.5 a $6.1 \mathrm{~mm}$ de largo, de 3.2 a $7 \mathrm{~mm}$ de ancho, serícea, lanulosa o estrigosa, verde-grisácea. Semillas ovoides, de 2.5 a $3.2 \mathrm{~mm}$ de largo, de 1.7 a $2.4 \mathrm{~mm}$ de ancho, base truncada, ápice apiculado, grisáceas, pardas o purpúreas, carúncula ausente, rafe a veces evidente, a menudo con una cicatriz apical crateriforme o linear de 0.2 a 0.5 $\mathrm{mm}$ de largo, blanquecina o parda, superficie a veces lagunar, punteada, ligera a fuertemente estriada y/o reticulada.

Distribución y ecología: En México se encuentra en Chiapas, Colima, Durango, Guanajuato, Guerrero, Jalisco, México, Michoacán, Morelos, Nayarit, Oaxaca, Puebla, Querétaro, San Luis Potosí, Sinaloa, Sonora y Zacatecas (Figura 2). En Centroamérica en Costa Rica, El Salvador, Guatemala, Honduras y Nicaragua. Crece en laderas y terrenos planos con bosque tropical caducifolio, matorral xerófilo y pastizal; en suelos calizos, arcillosos y rocosos, desde 300 hasta $1,950 \mathrm{~m}$. Florece y fructifica durante todo en año. Especie visitada por avispas.

Nombre común: guinare. 
Argythamnia guatemalensis es una especie con amplio rango de variación morfológica. Se han propuesto especies afines y variedades; sin embargo, con el estudio de más de cien ejemplares de México y Centroamérica resulta evidente la plasticidad de los caracteres empleados como diagnósticos. En general, hay dos grupos morfológicos dentro de A. guatemalensis, pero éstos representan extremos de variación y resulta imposible distinguirlos con claridad ya que no hay diferencias absolutas y la variación es continua.

Müller (1865) describió Argythamnia guatemalensis con base en dos sintipos, uno de ellos provenía de Guatemala y el otro de Puebla. Estas dos colectas pertenecen a diferentes grupos morfológicos. El lectotipo representa a un grupo de plantas con hojas relativamente pequeñas, aserruladas a subenteras, con tricomas cortos que cubren densamente el haz y el envés, y semillas estriadas sin reticulación definida. Plantas con estas características habitan principalmente en matorral xerófilo en el centro y hacia el occidente de México (Jalisco, Durango, Nayarit, Oaxaca, Puebla, Querétaro y Zacatecas). A pesar de que el sintipo de Guatemala fué destruido, dado su origen geográfico, puede asumirse que correspondía al grupo de plantas de apariencia grisácea, con hojas grandes y aserradas, con indumento seríceo en el envés y seríceo-glabrescente en el haz, semillas profundamente reticuladas con estrías escasas o ausentes. Las plantas con dichas características habitan zonas más húmedas, medias y bajas, relativamente cercanas a las costas del Pacífico en México y Centroamérica. Forman un grupo distinguible respecto del que habita en el centro de México, en el que destaca la tendencia a presentar estilos más cortos. Esta característica representa un extremo de la variación de la especie, que algunos autores han considerado como especies distintas, como es el caso de $D$. discolor Brandegee y $D$. sinaloae I.M.Johnst. En México, este morfotipo se encuentra en los estados de Chiapas, Colima, Guerrero, Jalisco, Michoacán, Morelos, Nayarit, Oaxaca y Sinaloa y se extiende hasta Costa Rica. Pax y Hoffmann (1914) reconocieron material de Sinaloa como $D$. guatemalensis var. discolor y lo distinguieron de la variedad típica por tener hojas relativamente más grandes (6-8 cm de largo) y flores femeninas con sépalos glanduloso-denticulados. Cabe destacar que este tipo de sépalos se encuentran presentes en el amplio espectro de variación de A. guatemalensis pero tienden a ser más conspicuos en algunas plantas del grupo del Pacífico.

En algunas zonas, principalmente elevaciones medias de los estados de Jalisco, México, Michoacán, Morelos, Sonora y Zacatecas, se encuentran plantas con otras combinaciones de caracteres de ambos grupos y a veces con rasgos intermedios. Algunas presentan indumento seríceo y semillas estriadas con depresiones poco profundas; otras tienen un indumento corto, hojas aserruladas, el haz glabrescente y semillas profundamente reticuladas, sin estrías; y otras más presentan hojas aserruladas, indumento corto y semillas medianamente estriadas y moderadamente reticuladas res- pecto a los extremos. Por estos motivos, hasta el momento resulta sumamente complejo distinguir más de una entidad dentro de A. guatemalensis.

En un trabajo sobre las Euphorbiaceae de Nueva Galicia, McVaugh (1995) enlista tres entidades que aquí reconocemos como parte de Argythamnia guatemalensis. La primera corresponde a $D$. discolor (citada con base en la colecta: Colima, Río Salado, McVaugh 14996 (MICH) como Argythamnia discolor; sin embargo, cabe aclarar que no existe tal combinación). La segunda es A. guatemalensis var. guatemalensis, que aunque no figura en su zona de estudio, es incluida en la clave; y la tercera es una variedad ampliamente distribuida en Nueva Galicia que McVaugh propone como A. guatemalensis var. barrancana. Dada la complejidad morfológica de A. guatemalensis y a que el origen de este nombre se basó en dos sintipos pertenecientes a diferentes grupos morfológicos, hay una confusión importante que se aclara enseguida. McVaugh describió la var. barrancana sin tomar en cuenta la lectotipificación de la especie (Ingram, 1964), ya que menciona que el material tipo (no examinado por él) es la colecta de Friedrichsthal proveniente de Guatemala. Sin embargo, el tipo de la var. barrancana proviene de Zacatecas y corresponde a la misma entidad que el lectotipo de Puebla (F. M. Liebmann 5717). Por tanto, A. guatemalensis var. barrancana representa un sinónimo de A. guatemalensis sensu stricto. McVaugh distinguió estas dos variedades con base en la ornamentación de la semilla: la var. guatemalensis con semillas con los bordes del retículo bien definido y la var. barrancana con semillas estriadas y con depresiones poco profundas. Aunque se considera conveniente reconocer una sola especie sin taxa intraespecíficos, si dos variedades son reconocidas (como hizo McVaugh), las plantas del centro de México con semillas estriadas sin reticulación definida deben ser consideradas como var. guatemalensis; mientras que las del Centroamérica y occidente de México, con semillas reticuladas profundamente, deben ser consideradas como var. discolor.

Cabe mencionar que Argythamnia guatemalensis ha sido confundida con A. tinctoria, una especie descrita por Millspaugh (1896) con base en colectas de Yucatán (México) y Nicaragua. Resulta que estas colectas pertenecen a dos subgéneros distintos; mientras el holotipo de A. tinctoria proveniente de Yucatán [G. F. Gaumer 426 (F)] sí representa esta especie; un paratipo (C. Wright s.n., GH) colectado en Nicaragua corresponde a A. guatemalensis (Ingram, 1964). Probablemente por esta discrepancia, Croizat (1945) erróneamente señaló a A. tinctoria como sinónimo de A. guatemalensis.

Por otra parte, ejemplares de otras especies han sido frecuentemente determinados como Argythamnia guatemalensis, tal es el caso de algunos que pertenecen a A. ingramii y $A$. manzanilloana. McVaugh (1995) notó que colectas de Veracruz y San Luis Potosí identificadas como A. guatemalensis var. guatemalensis parecían pertenecer a un diferente taxón cercanamente relacionado. Efectivamente, Argythamnia in- 
gramii (especie a la que se refería McVaugh), así como $A$. manzanilloana son distintas y cercanamente emparentadas con A. guatemalensis. Se diferencian de A. guatemalensis por tener estaminodios plumosos y flores pistiladas con los pétalos rómbicos a elípticos, en lugar de estaminodios glabros y flores pistiladas con los pétalos lanceolados.

Ejemplares adicionales examinados: MÉXICO. CHIAPAS: Paderón Tonala, Matuda 16349 (FCME, MICH, MO, US); Carretera 190, 28 km al N de El Jocote, 37 km de La Trinitaria, Stevens 25738 (MEXU). COLIMA: low mountains of gypsum and slate, seaward-facing slopes $2-5 \mathrm{~km}$ below the submmit of the hwy. pass, 19-21 km S-SW from Colima, McVaugh 26192 (MICH); steep buffs above Río Salado, 5 mi S of Colima, barranca south of the river, McVaugh 14996 $(\mathrm{MICH})$; mountain summits near pass ca. $11 \mathrm{mi} \mathrm{S}-\mathrm{SW}$ of Colima on Manzanillo road, McVaugh 18063 (MICH). DURANGO: Mpio. El Mezquital, Balneario La Joya, 300 $\mathrm{m}$ antes de la entrada, por el camino, González y Cinebell 6363 (IEB). GUANAJUATO: Mpio. Xichú, $5 \mathrm{~km}$ al E de Las Adjuntas sobre el camino a Huamúchil, Rzedowski 53435 (IEB). GUERRERO: Mpio. Coahuayutla de Guerrero, Matamoros de Guerrero, $7.18 \mathrm{~km}$ al NO, Calónico 11970 (FCME); Distr. Coyuca, Arcelia, Hinton 6600 (ENCB, F, GH, MICH, NY, US); Mpio. Zumpango del Río, $2 \mathrm{~km}$ al S de Mexcala, Rzedowski 26907 (ENCB, IBUG, MEXU, UAMIZ, XAL). JALISCO: W slopes of Barranca del Río Santiago, near Guadalajara, MEX $411.2 \mathrm{mi}$ S del puente Guadalupe, Anderson y Anderson 5112 (ENCB, IBUG, MEXU, MICH, NY); Mpio. San Cristóbal de la Barranca, El Tablón, $1.4 \mathrm{~km}$ al N de San Cristóbal de la Barranca, a orillas del Río Cuixtla, Carrillo-Reyes, Barba y Ortíz-Catedral 1833 (IBUG); Bolaños, Rose 2920 (GH, US); Mpio. Tuxcacuesco, 5-6 km al WSW de Tuxcacuesco, 5-6 km al ENE de Zenzontla, Cerro del Palacio, Santana y Benz 5899 (IEB). MÉXICO: Distr. Temascaltepec, Nanchititla, Hinton 3618 (F, GH, MO, NY, US). MICHOACÁN: Mpio. Aquila, Santa Cruz de Cachán, Guerrero 946 (ENCB, IEB, MEXU, XAL); Mpio. Arteaga, sobre MEX 37, ca. $75 \mathrm{~km}$ al N de Arteaga y $1 \mathrm{~km}$ al $\mathrm{S}$ del descansadero, Ramírez-Amezcua et al. 452 (IEB); Mpio. Múgica, afluente del Río Marqués, $5.5 \mathrm{~km}$ NE de la salida a Nueva Italia por la autopista Morelia-Lázaro Cárdenas, Ramírez-Amezcua, Steinmann y Carranza 345 (IEB). MORELOS: Mpio. Moyotepec, $3 \mathrm{~km}$ al S de Las Piedras, Lott 294 (ENCB, MEXU); Xochitepec, Lyonnet 2182 (CAS, ENCB, FCME, MEXU, MO, US). NAYARIT: Mpio. Nayar, $500 \mathrm{~m}$ al S de Jesús María, río Santiago, Flores et al. 1779 (MEXU, MICH, MO); $2 \mathrm{~km}$ al $\mathrm{N}$ de Rancho Viejo, brecha a San Juan Peyotán, Tenorio y Flores 16328 (MEXU, MICH, MO). OAXACA: $10 \mathrm{~km}$ al SSE de Teotitlán del camino, sobre la carretera a Cuicatlán, Rzedowski 37185 (ENCB, IEB, MEXU, MO, XAL); Mpio. Cuicatlán, $6 \mathrm{~km}$ del entronque de la brecha a San Pedro Jocotipac con la carretera Tehuacán-Cuicatlán, Tenorio y Martínez 17905 (ARIZ, CAS, GH,
MEXU); Mpio. Tepelmeme, subida del Cacalosuchil, Tenorio et al. 6923 (IEB, MEXU, MO, XAL). PUEBLA: 8 mi by road SE of Coxcatlán on road from Tehuacán to Teotitlán del Camino, Anderson y Anderson 5338 (ENCB, IEB, MEXU, $\mathrm{MICH}) ; 5 \mathrm{~km}$ al E de Santa Catarina Tehuixtla, unos $5 \mathrm{~km}$ al SE de Tepoztitlán, Medrano, Jaramillo y Villaseñor F-1342 (MEXU, MO, NY); Barranca de Tzentzo, $12 \mathrm{~km}$ al W de Molcaxac, Tenorio y Frame 12197 (F, MEXU, TEX). QUERÉTARO: Mpio. Tolimán, $3 \mathrm{~km}$ al S de Camargo, Fernández 2884 (ENCB, IEB, MEXU, NY); Jalpan, 20 km (by road) NNW of Jalpan, along the road to Arroyo Seco, Steinmann et al. 713 (IBUG, IEB, MEXU, NY); Mpio. Peñamiller, along the road to Aldama, $7.8 \mathrm{~km}$ (by road) northwest of Peñamiller, small canyon above the road, Steinmann y Zamudio 2737 (IEB). SAN LUIS POTOSÍ: $8 \mathrm{mi}$ al W de Río Verde, Johnston y Crutchfield 5650 (MICH, TEX). SINALOA: 5 $\mathrm{km}$ al W de Concordia, Breedlove 36428 (CAS, MICH, MO); Cerro Llano Redondo, W of Caimanero, Gentry 7100 (CAS, DS, F, GH, NY, UC, US); Mpio. San Ignacio, $4 \mathrm{~km}$ al N de San Ignacio, R.V.A. y J.A.G.G. 9302 (MEXU). SONORA: Near Agua Caliente, N of Álamos, Gentry 4844 (DS, GH, MEXU, MICH, MO, NY, UC); Tres Marías, ca. $28 \mathrm{~km} \mathrm{E} \mathrm{of}$ MEX 15 in Navojoa, Van Devender, Reina y Yetman 95-1103 (IEB, MEXU, TEX). ZACATECAS: La Ventanilla, $2.5 \mathrm{~km}$ al NE del Rancho San Luis (San Luis El Gato), Cañón del Río Chico, Carrillo-Reyes y Puig 3228 (IBUG, IEB); Mpio. Moyahua, cerro La Cantarilla, $8.5 \mathrm{~km}$ al S de Moyahua, Enríquez 713 (MEXU, UAZ); $5 \mathrm{mi}$ al NE de Jalpa, McVaugh 18480 (CAS, IEB, MEXU, MICH).

Argythamnia heterantha (Zucc.) Müll.Arg. in DC., Prodr. 15 (2):735. 1866. Ditaxis heterantha Zucc., Abh. Math.Phys. Cl. Königl. Bayer Akad. Wiss. 1:290. 1832. Tipo: México, Hidalgo, Tolimán, 1827, W. F. Karwinski s.n. [holotipo M, no visto, foto (Field Negative \#19493)].

Argythamnia argentea Brandegee, Univ. Calif. Publ. Bot. 4(15):273. 1912; non Argythamnia argentea Millsp., 1906. Tipo: México, San Luis Potosí, collected near Minas de San Rafael, May 1911, C. A. Purpus 5459 (holotipo UC; isotipos MO, NY).

Arbusto o subarbusto de hasta $3 \mathrm{~m}$ de alto, monoico, tallos erectos, corteza grisácea, ramillas ligeramente angulosas por ligeras líneas verticales, seríceas o lanulosas, verdosas, grisáceas o rara vez rosadas. Hojas con estípulas generalmente inconspicuas, caedizas, elípticas, ovadas o subuladas, de 0.5 a $8 \mathrm{~mm}$ de largo, glabras, seríceas o pilosulosas, margen entero a subentero, con dientes reducidos a puntuaciones no específicamente glandulares; pecíolo acanalado, de 0.7 a $11 \mathrm{~mm}$ de largo, indumento igual al de las ramillas; lámina ovada o elíptica, de 2 a $12.5 \mathrm{~cm}$ de largo, de 0.6 a $6.2 \mathrm{~cm}$ de ancho, a veces coriáceas, con 3 o 5 nervaduras basales o suprabasales, envés lanoso, lanuloso o seríceo, haz 
seríceo, pilosuloso o lanuloso; base obtusa, decurrente o redondeada; ápice agudo o acuminado; margen aserrado, aserrulado o subentero, a veces revoluto, los dientes papilados o reducidos a una excrecencia esferoidal no específicamente glandular. Inflorescencias de 2.3 a $6 \mathrm{~cm}$ de largo, con una flor pistilada en la base, rara vez 2, y de 3 a 6 flores estaminadas en la parte distal; brácteas ovadas a elípticas, de 2.2 a $10 \mathrm{~mm}$ de largo, de 0.9 a $1.5 \mathrm{~mm}$ de ancho, externamente seríceas, lanulosas, pilosulosas o glabrescentes, internamente glabras, glabrescentes, lanulosas o pilosulosas; ápice agudo; margen entero. Flores estaminadas sobre pedicelos seríceos de 0.6 a $1.5 \mathrm{~mm}$ de largo; sépalos 5, elípticos, de 2.8 a $5.3 \mathrm{~mm}$ de largo, de 0.9 a $1.5 \mathrm{~mm}$ de ancho, ápice agudo, margen entero, externamente seríceos, lanulosos o pilosos, internamente glabros o pilosulosos, pétalos 5, elípticos o espatulados, cuculados, de 2.2 a $3.8 \mathrm{~mm}$ de largo, de 1.2 a $2.2 \mathrm{~mm}$ de ancho, base clavada, ápice obtuso, libres de la columna estaminal, blancos, amarillentos o rosados, margen ondulado o eroso, externamente estrigulosos, pilosos, pilosulosos en la parte media, a veces glabros, internamente glabros, estambres 10, dispuestos en 2 verticilos de 5 cada uno, columna estaminal de 1.4 a $3.5 \mathrm{~mm}$ de largo, de 0.4 a $0.7 \mathrm{~mm}$ de ancho, amarillenta, rojiza o purpúrea, la parte libre del filamento de 0.5 a $1.9 \mathrm{~mm}$ de largo, estaminodios ausentes o 2 o 3 cuando presentes, de 0.1 a $0.5 \mathrm{~mm}$ de largo; glándulas ovadas a oblongas, de 0.3 a $0.6 \mathrm{~mm}$ de largo, de 0.4 a $0.8 \mathrm{~mm}$ de ancho, glabras, amarillentas, ápice obtuso, margen ondulado o entero. Flores pistiladas sobre pedicelos pilosos, seríceos, estrigosos o glabrescentes de 4 a 12 $\mathrm{mm}$ de largo, de 1 a $1.6 \mathrm{~mm}$ de grueso; sépalos 5, ovados, de 5 a $10 \mathrm{~mm}$ de largo, de 3.2 a $6 \mathrm{~mm}$ de ancho, ápice agudo u obtuso, margen entero, externamente lanulosos, estrigosos o pilosos, internamente pilosulosos a glabrescentes; pétalos 5 , reducidos, fliliformes a obovados, de 0.7 a $1.5 \mathrm{~mm}$ de largo, de 0.2 a $0.6 \mathrm{~mm}$ de ancho, amarillentos, base clavada, ápice agudo, externamente pilosulosos con los tricomas agregados en el centro o glabros, internamente glabros o pilosulosos, márgen entero a eroso; ovario glabro o glabrescente, estilos glabrescentes o con un mechón de tricomas en el centro, de 1.2 a $2 \mathrm{~mm}$ de largo, libres de 0.4 a $1 \mathrm{~mm}$, purpúreos; estigmas aplanados, amarillentos o purpúreos; glándulas oblatas, de 0.3 a $0.5 \mathrm{~mm}$ de largo, de 0.5 a $1.1 \mathrm{~mm}$ de ancho, glabras, amarillentas, ápice obtuso, margen ondulado. Cápsula de 8 a $11 \mathrm{~mm}$ de largo, de 7.8 a $16 \mathrm{~mm}$ de ancho, glabra o con escasos tricomas caedizos, purpúrea. Semillas ovoides, de 6.6 a $8 \mathrm{~mm}$ de largo, de 6.5 a $9 \mathrm{~mm}$ de ancho, base truncada, ápice apiculado, negruzcas o pardas, carúncula ausente, rafe evidente, con una cicatriz apical circular o linear de 0.5 a 3 $\mathrm{mm}$ de largo, blanquecina, rugosas.

Distribución y ecología: Endémica de México; se encuentra en Aguascalientes, Baja California Sur, Colima, Guanajuato, Hidalgo, Jalisco, Michoacán, Nayarit, Querétaro, San Luis Potosí, Sinaloa, Tamaulipas, Veracruz y Zacatecas (Figura
3). Crece en bosque tropical caducifolio y matorral xerófilo en suelos arenosos, arcillosos, calizos y rocosos; desde 500 hasta 2,300 m. Eventualmente se cultiva en cercas y solares. Florece y fructifica prácticamente durante todo el año.

Nombres comunes: azafrán de bolita, azafranillo, azafranillo de bolita.

Según la evidencia morfológica y los datos moleculares obtenidos, Argythamnia heterantha y A. pringlei están muy cercanamente relacionadas (Ramírez-Amezcua, 2011). Se distingue a la primera por tener las cápsulas glabras, en contraste con las cápsulas densamente pubescentes de la segunda. Cabe mencionar que algunas plantas de A. heterantha tienen cápsulas con tricomas malpigiáceos dispersos y caedizos y la distinción entre ambas especies no siempre es clara (ver discusión bajo A. pringlei).

Argythamnia heterantha se distribuye desde Baja California Sur hasta Veracruz, pero la mayoría de las colectas son del centro del país. Parece que en algunos estados solamente se encuentra cultivada o como remanente de algún posible cultivo. La mayoría de las etiquetas no proveen suficiente información y no siempre es posible determinar si la colecta pertenece a una población nativa o introducida. Se conocen poblaciones silvestres en Querétaro e Hidalgo. Las tres colectas de Baja California Sur son de sitios cercanos y, a juzgar por la información de las etiquetas, también provienen de plantas silvestres. Hay una o dos colectas de los estados de Colima, Nayarit, San Luis Potosí, Sinaloa, Tamaulipas y Veracruz, pero desafortunadamente carecen de esta información; de Michoacán se conocen tres colectas; dos provienen de plantas cultivadas, y la tercera [Rzedowski 39098 (ENCB, IEB, MEXU)] no corresponde a una planta cultivada (J. Rzedowski com. pers.), los esfuerzos por reencontrar alguna población en la zona han sido en vano. De Jalisco se conocen varias plantas cultivadas y otras sin datos al respecto; según Raymundo Ramírez (com. pers.) no se encuentra de manera silvestre en el estado.

Argythamnia heterantha se conoce como "azafranillo" o "azafrán de bolita" debido al tinte amarillo que se obtiene de sus semillas. El endospermo sirve como colorante, saborizante y aromatizante de alimentos. Se cultiva esporádicamente en patios y límites de casas de algunos poblados y aunque actualmente la importancia económica de la semilla es baja, tiene valor comercial y alcanza precios competitivos a nivel local. Es una planta con alto potencial ya que su cultivo tiene baja demanda de agua y requiere de pocos cuidados. La composición de su semilla es similar a la de algodón y girasol, de manera que no sólo constituye una fuente importante de colorante, sino también de aceite y proteína (Méndez-Robles et al., 2004).

Ejemplares adicionales examinados: MÉXICO. AGUASCALIENTES: Mpio. Calvillo, cañada extremo sur de la presa La Codorniz, García 4095 (HUAA). BAJA CALIFOR- 
NIA SUR: Sierra de la Laguna, NE of Todos Santos, vicinity of Valle Laguna, at top of the sierra, NE of canyon La Burrera and Rancho Corral Grande, Rebman et al. 5789 (IEB). COLIMA: Paso del Río, Emrick 19 (F). GUANAJUATO: Guanajuato, Duges 204a (GH); Mpio Atareja, Mina de la Liga, Ventura y López 8923 (IEB, MEXU, MICH, XAL). HIDALGO: Mpio. Tasquillo, $3 \mathrm{~km}$ al $\mathrm{N}$ del Puente Tasquillo que pasa por el río Tula, por la carretera que va a Zimapán, García, Delgado y Hernández 1038 (MEXU, ENCB, TEX); km 171 of México City-Laredo hwy, near Zimapán, Purpus 1453 (GH, NY, UC); Ixmiquilpan, Rose, Painter y Rose 8941 (F, GH, MO, NY, US); Huichapan, 24 jul. 1913, Salazar s.n. (MEXU); Tecozautla, 24 jul. 1913, Salazar s.n. (MEXU, US). JALISCO: Mpio. Ameca, San Martín de la Cal, cerca de Guadalajara, sept. 1892, Altamirano s.n. (MEXU); Mpio. Tenamaxtlán, vereda del poblado de Tenamaxtlán a El Picacho, Machuca y Cházaro 7949 (IBUG, IEB); Barranca near Guadalajara, Palmer 641 (MEXU, MO, US). MICHOACÁN: Mpio. Jiquilpan, Los Remedios, lote baldío en zona urbana, Ramírez-Amezcua et al. 638 (IEB); Mpio. Erongarícuaro, cerca de Oponguio, Rzedowski 39098 (ENCB, IBUG, IEB, MEXU). NAYARIT: Tepic, Gregg 988 (MO). QUERÉTARO: San Nicolás, entre San Juan del Río y Tequis, Argüelles 1783 (MEXU, NY); Jardín Botánico Regional de Cadereyta "Ing. Manuel González de Cosío", Hernández, Orozco y Orozco 9757 (FCME, MEXU); Mpio. San Joaquín, aprox. $1 \mathrm{~km}$ al E de San Joaquín, Huerta 1156 (IEB). SAN LUIS POTOSÍ: Camino Río Verde-Cárdenas, vía San Francisco, Rzedowski 5151 (ENCB). SINALOA: Mazatlán, González 674 (MEXU); San Ignacio, Narvaes y Salazar 674 (US). TAMAULIPAS: $6 \mathrm{~km}$ al E del Sauz, al NE de Tula, Medrano 10122 (MEXU). VERACRUZ: sin localidad, Purpus 16452 (F); ZACATECAS: García de la Cadena, Ornelas, 812 (IBUG).

Argythamnia humilis (Engelm. \& A.Gray) Müll. Arg., Linnaea 34:147. 1865. Aphora humilis Engelm. \& A.Gray, Pl. Lindheim. 5: 262. 1845. Ditaxis humilis (Engelm. \& A.Gray) Pax in Engl. \& Prantl., Nat. Pflanzenfamilien 3 (5):45. 1890. Tipo: Estados Unidos de América, Texas, 1844, Lindheimer 306 (lectotipo GH, designado aquí; isolectotipo MO).

Aphora humilis se describió en un trabajo basado en las colectas de Lindheimer. El protólogo dice "in hard clayey soil, West of the Brazos. March-August (Also Texas, Drummond, collection second No. 230 and Wright)", sin designar un tipo. En la colección del Herbario GH, hay un ejemplar con tres colectas diferentes: "Texas, 1844, Lindheimer 306"; "Texas, Drum., Coll. 2, no 230"; y "Texas, Wright", que corresponden a las citadas por Engelmann y Gray. No se conoce lectotipificación, pero ha de mencionarse que Wolf (1988) citó a Lindheimer 306 (MO) como isotipo, algo erróneo ya que había tres sintipos. Elegimos la colecta de Lindheimer como lectotipo dado que es la más completa.
Aphora laevis A.Gray ex Torr., Rep. U.S. Mex. Bound. 2(1):196(-197). 1858. Argythamnia laevis (A.Gray ex Torr.) Müll. Arg., Linnaea 34:147. 1865. Ditaxis laevis (A.Gray ex Torr.) A.Heller, Cat. N. Amer. Pl. 5. 1898. Ditaxis humilis (Engelm. \& A.Gray) Pax f. laevis (A.Gray ex Torr.) B.L.Turner, Sida 19(3):621(-622). 2001. Tipo: Estados Unidos de América, Western Texas, 23 ago. 1981, C. Wright 1798 pro parte (holotipo $\mathrm{GH}$ ).

Argythamnia humilis (Engelm. \& A.Gray) Müll. Arg. var. leiosperma Waterfl., Rhodora 73:553(-554). 1971. Ditaxis humilis (Engelm. \& A.Gray) Pax var. leiosperma (Waterfl.) Radcl.-Sm. \& Govaerts, Kew Bull. 52(2):479. 1997. Tipo: Estados Unidos de América, Oklahoma, Cimarron Co, top of Black Mesa, 3 mi north of Kenton, 07 oct. 1950, U. T. Waterfall 9753 (holotipo OKLA).

Hierba perenne de hasta $30 \mathrm{~cm}$ de alto, monoica (rara vez dioica), tallos ascendentes con cicatrices notorias en los nudos, corteza fisurada y amarillenta, ramillas con ligeras líneas verticales, estrigosas, seríceas o glabras. Hojas con estípulas persistentes, ovadas o lanceoladas, de 0.3 a 1.4 $\mathrm{mm}$ de largo, amarillentas o verdosas, estrigosas o glabras, margen aserrulado; pecíolo acanalado, de 2 a $7 \mathrm{~mm}$ de largo; lámina elíptica, obovada o linear, de 0.5 a $5.3 \mathrm{~cm}$ de largo, de 0.2 a $1.6 \mathrm{~cm}$ de ancho, con 3 nervaduras suprabasales, generalmente notorias, estrigosa, estrigulosa o glabra; base decurrente o atenuada; ápice agudo, mucronado, obcordado u obtuso; margen entero, a veces ligeramente revoluto. Inflorescencias de 7 a $9 \mathrm{~mm}$ de largo, bisexuales o rara vez unisexuales (de flores estaminadas), con una flor pistilada en la base y de 2 a 8 flores estaminadas en la parte distal; brácteas ovadas o lanceoladas, de 0.8 a $2.5 \mathrm{~mm}$ de largo, de 0.7 a $0.8 \mathrm{~mm}$ de ancho, externamente estrigulosas, internamente glabras, ápice agudo; margen entero, ondulado o aserrulado. Flores estaminadas sobre pedicelos seríceos o estrigosos de 0.4 a $1.6 \mathrm{~mm}$ de largo; sépalos 5, lanceolados, de 2.4 a $3.3 \mathrm{~mm}$ de largo, de 0.3 a $0.8 \mathrm{~mm}$ de ancho, ápice agudo, frecuentemente glandular, margen entero, externamente estrigulosos, internamente glabros; pétalos 5, elípticos, de 1.5 a $2.6 \mathrm{~mm}$ de largo, de 0.4 a $0.8 \mathrm{~mm}$ de ancho, base ligeramente atenuada, ápice agudo, libres de la columna estaminal, blanquecinos o purpúreos, margen entero u ondulado; estambres 10 (7-9), dispuestos en 2 verticilos de 5 cada uno, o el verticilo basal de cinco estambres y los demás en el apical, columna de 0.7 a $1.6 \mathrm{~mm}$ de largo, la parte libre del filamento de 0.3 a $0.4 \mathrm{~mm}$ de largo, 2 o 3 estaminodios apicales, de $0.1 \mathrm{~mm}$ de largo; glándulas ovadas a filiformes, de 0.4 a $0.8 \mathrm{~mm}$ de largo, de 0.2 a 0.3 $\mathrm{mm}$ de ancho, glabras o rara vez con tricomas, purpúreas, ápice agudo. Flores pistiladas sobre pedicelos estrigosos, seríceos o glabros de 0.5 a $1.5 \mathrm{~mm}$ de largo; sépalos 5, elípticos, de 4 a $5.2 \mathrm{~mm}$ de largo, de 0.9 a $2.5 \mathrm{~mm}$ de ancho, ápice agudo, margen entero, glandular, papiloso u ondulado, 
externamente estrigulosos, glabrescentes o glabros, internamente glabros; pétalos 5, reducidos, elípticos o filiformes, de 0.3 a $1.7 \mathrm{~mm}$ de largo, de 0.3 a $0.4 \mathrm{~mm}$ de ancho, base atenuada, ápice agudo, amarillentos, margen ondulado o entero, glabros en ambas caras; ovario hispiduloso, estrigoso, estriguloso o glabro, estilos con tricomas al centro, de 0.7 a $1.3 \mathrm{~mm}$ de largo, libres en 0.6 a $1.1 \mathrm{~mm}$, purpúreos; estigmas aplanados, dilatados, amarillentos o purpúreos; glándulas filiformes a oblongas, de 0.3 a $1.5 \mathrm{~mm}$ de largo, de 0.1 a $0.4 \mathrm{~mm}$ de ancho, amarillentas o purpúreas, ápice obtuso. Cápsulas de 1.6 a $3 \mathrm{~mm}$ de largo, de 2.5 a $4.2 \mathrm{~mm}$ de ancho, hispidulosas, estrigosas, estrigulosas, glabras o glabrescentes, purpúreas. Semillas globosas, de 1.8 a $2.5 \mathrm{~mm}$ de largo, 1.5 a $2.5 \mathrm{~mm}$ de ancho, grisáceas, carúncula ausente, rafe ligeramente marcado, papilosas.

Distribución y ecología: En México se encuentra en Chihuahua, Coahuila, Nuevo León y Tamaulipas (Figura 3); en Estados Unidos de América en Texas. Crece en bosque de encino-pino, pino-encino-Pseudotsuga, matorral xerófilo y pastizal, en suelos arcillosos y calcáreos; desde 270 hasta 2,500 m. Florece y fructifica de marzo a abril y de julio a diciembre.

Plantas glabras o esencialmente glabras han sido reconocidas como Argythamnia laevis, pero Turner (2001) estudió algunas poblaciones de la especie y comprobó que las plantas glabras son raras y aparentemente no forman poblaciones distintas. Por ello, estas plantas no se reconocen con ninguna categoría infraespecífica y se consideran parte de la variabilidad de A. humilis.

Ejemplares adicionales examinados: MÉXICO. CHIHUAHUA: Mpio. Buenaventura, Rancho Ojo Caliente, Enrique 89 (TEX). COAHUILA: Mpio. Ocampo, Sierra del Pino, ejido Acebuches, cañón La Vaca, 12 oct. 1991, Carranza et al. s.n. (TEX); Sierra del Pino, vicinity of La Noria, Johnston y Müller 632 (MICH); Santa Rosa Mountains, Marsh 1513 (GH, TEX). NUEVO LEÓN: $36 \mathrm{mi}$ al SE de Montemorelos sobre MEX 85, Dwyer et al. 23 (MO); $20 \mathrm{mi}$ E of General Bravo, Johnston 4360 (MEXU, MICH, TEX); Monterrey, Sierra Madre Mountains, Mueller y Mueller 450 (F, GH, MEXU, TEX). TAMAULIPAS: 31 mi out of Reynosa on the road to San Fernando, Johnston 4366 (MICH, TEX); 2 mi S of Tres Palos and one mile down the road to Loreto, Johnston 4885A (MICH, TEX); throughout the Lower Rio Grande Valley, Consuelo Ranch, $20 \mathrm{mi}$ S of Matamoros, Runyon 4733 (TEX).

Argythamnia ingramii Y.Ramírez-Amezcua et V.W.Steinm. sp. nov. (Figura 5).

Tipo: MÉXICO, VERACRUZ. Mpio. Dos Ríos, La Cumbre, $250 \mathrm{~m}, 5$ jul. 1973, Ventura 8542 (holotipo IEB, isotipos: ENCB, MEXU, XAL).
Perennial herb or subshrub to $1 \mathrm{~m}$ tall, monoecious, stems erect, strigulose to sericeous. Stipules persistent, lanceolate, subulate triangular or linear, 0.9-2 mm long. Petiole 1-7 $\mathrm{mm}$ long. Leaves elliptic, $2.5-7.2 \mathrm{~cm}$ long, $0.4-2.5 \mathrm{~cm}$ wide; base acute attenuate or rounded; apex acute, sometimes mucronate; margin serrate to serrulate. Inflorescences $4-10$ $\mathrm{mm}$ long, with a pistillate flower at the base and (2) 4-8; bracts elliptic, 0.4-2 mm long, 0.5-1 mm wide. Staminate flowers with pedicels 0.5-0.9 mm long; sepals 5, lanceolate, 1.7-2.8 mm long, 0.5-0.8 $\mathrm{mm}$ wide, apex acute, margin entire; petals 5, lanceolate, 1.8-2.8 mm long, 0.5-1.4 mm wide, base attenuate to acute, apex acute to obtuse, adnate to the staminal column, yellowish to purple, margin entire, undulate, erose or ciliate, stamens 10 , arranged in two whorls of 5, 0.7-2.5 mm long, free portion of the filaments 0.3-0.4 mm long. Pistillate flowers with pedicels $0.5-2 \mathrm{~mm}$ long; sepals 5 elliptic to lanceolate, 3.2-5.6 mm long, 0.6$1.8 \mathrm{~mm}$ wide, apex acute, margin entire to serrulate; petals 5, elliptic, $1-2 \mathrm{~mm}$ long, $0.5-1.8 \mathrm{~mm}$ wide, base attenuate, apex acute, yellowish, pink or blackish in the center, margin ciliate, fimbriate or serrulate; ovary strigose or hispidulose, styles 0.5-1.4 mm long, free from 0.5-1.1 mm; stigmas flattened, sometimes only slightly. Capsules $2-3.4 \mathrm{~mm}$ long, 2-4.2 mm wide, strigose to hispidulose. Seeds globose, 1.8$2.4 \mathrm{~mm}$ long, 1.6-1.9 mm wide, base trucate, apex apiculate, surface with depressions, striate and/or reticulae.

Hierba perenne o subarbusto de hasta $1 \mathrm{~m}$ de alto, monoico, tallos erectos frecuentemente con cicatrices notorias en los nudos, corteza fisurada, amarillenta, ramillas con ligeras líneas verticales, estrigulosas o seríceas. Hojas con estípulas persistentes, lanceoladas, subuladas, triangulares o lineares, de 0.9 a $2 \mathrm{~mm}$ de largo, estrigosas, seríceas o glabrescentes, ápice agudo; pecíolo acanalado, de 1 a $7 \mathrm{~mm}$ de largo, indumento igual al de las ramillas; lámina elíptica, de 2.5 a $7.2 \mathrm{~cm}$ de largo, de 0.4 a $2.5 \mathrm{~cm}$ de ancho, verde o purpúrea, con tonalidades doradas por el indumento, con 3 nervaduras basales, envés estrigoso, con los tricomas agregados en las nervaduras, haz estrigoso a estriguloso; base aguda, atenuada o redondeada; ápice agudo, a veces mucronado, con una excrecencia apical no específicamente glandular; margen aserrado o aserrulado, con los dientes papilados. Inflorescencias de 4 a $10 \mathrm{~mm}$ de largo, con una flor pistilada en la base, de (2) 4 a 8 flores estaminadas en la parte distal; brácteas elípticas, de 0.4 a $2 \mathrm{~mm}$ de largo, de 0.5 a $1 \mathrm{~mm}$ de ancho, verdes, externamente estrigulosa, con los tricomas agregados en el centro, internamente glabras, fimbriadas; margen entero. Flores estaminadas sobre pedicelos estrigosos o seríceos de 0.5 a $0.9 \mathrm{~mm}$ de largo; sépalos 5 , lanceolados, de 1.7 a $2.8 \mathrm{~mm}$ de largo, de 0.5 a $0.8 \mathrm{~mm}$ de ancho, ápice agudo, margen entero, externamente seríceos o estrigosos, internamente glabros o estrigulosos; pétalos 5, lanceolados, de 1.8 a $2.8 \mathrm{~mm}$ de largo, de 0.5 a $1.4 \mathrm{~mm}$ de ancho, base atenuada o aguda, ápice agudo a obtuso, adnados a 
la columna estaminal, amarillentos o purpúreos, margen entero, ondulado, eroso o ciliado, externamente seríceos, con los tricomas agregados en el centro, internamente glabros o estrigulosos; estambres 10, dispuestos en 2 verticilos de 5 cada uno, columna estaminal rojiza o amarillenta, inserta en la corola, de 0.7 a $2.5 \mathrm{~mm}$ de largo, la parte libre del filamento de 0.3 a $0.4 \mathrm{~mm}$ de largo, 4 o 5 estaminodios filiformes, de 0.3 a $0.8 \mathrm{~mm}$ de largo, plumosos; glándulas ovadas, ligeramente cóncavas, de 0.2 a $0.4 \mathrm{~mm}$ de largo, de 0.2 a $0.6 \mathrm{~mm}$ de ancho, glabras, amarillentas o purpúreas, ápice agudo, hendido o truncado. Flores pistiladas sobre pedicelos seríceos o estrigosos, de 0.5 a $2 \mathrm{~mm}$ de largo; sépalos 5 , elípticos o lanceolados, de 3.2 a $5.6 \mathrm{~mm}$ de largo, de 0.6 a $1.8 \mathrm{~mm}$ de ancho, ápice agudo, margen entero o aserrulado, externamente seríceos o estrigosos, internamente estrigulosos, glabros o estrigosos hacia el ápice y glabros en la base; pétalos 5, elípticos, de 1 a $2 \mathrm{~mm}$ de largo, de 0.5 a $1.8 \mathrm{~mm}$ de ancho, base atenuada, ápice agudo, amarillentos, rosados o negruzcos en la parte media, margen ciliado, fimbriado o aserrulado, externamente estrigosos en la parte media, internamente glabros; ovario estrigoso o hispiduloso, estilos con tricomas agregados en un mechón al centro, de 0.5 a $1.4 \mathrm{~mm}$ de largo, libres de 0.5 a $1.1 \mathrm{~mm}$, amarillentos o purpúreos; estigmas aplanados, a veces sólo ligeramente, amarillentos; glándulas ovadas u oblatas, de 0.2 a $0.4 \mathrm{~mm}$ de largo, de 0.2 a $0.7 \mathrm{~mm}$ de ancho, glabras, amarillentas, ápice obtuso, margen entero. Cápsulas de 2 a $3.4 \mathrm{~mm}$ de largo, de 2 a $4.2 \mathrm{~mm}$ de ancho, estrigosas o hispidulosas, verdes. Semillas globosas, de 1.8 a $2.4 \mathrm{~mm}$ de largo, de 1.6 a $1.9 \mathrm{~mm}$ de ancho, truncadas en la base, ápice apiculado, grisáceas o pardas, carúncula ausente, rafe frecuentemente evidente, superficie con depresiones, estriadas y o reticuladas.

Distribución y ecología: Endémica de México; se encuentra en Quintana Roo, San Luis Potosí, Tamaulipas y Veracruz (Figura 4). Crece en bosque tropical caducifolio, en suelos arcillosos y pedregosos; en altitudes que van desde 60 hasta $450 \mathrm{~m}$. Colectada con flor y fruto de julio a diciembre.

Etimología: Esta especie se nombra en honor al Dr. John W. Ingram por sus importantes aportaciones en el estudio del género Argythamnia.

Argythamnia ingramii difiere de A. manzanilloana en las hojas escasamente aserruladas, el indumento de tricomas delgados y de color dorado, la columna que forman los estilos al unirse es corta y el androceo inserto en la corola; en contraste con las hojas aserruladas, los tricomas plateados y gruesos, la columna larga y el androceo generalmente exerto de A. manzanilloana. También puede confundirse con A. argothamnoides (Bertero ex Spreng.) J.W.Ingram, una especie que va desde Florida en Estados Unidos de América y las Antillas hasta Colombia y Venezuela. Argythamnia ingramii tiene estaminodios desarrollados y plumosos, mientras que en A. argothamnoides son inconspicuos, normalmente punctiformes y varían de glabros a pilosos. En los ejemplares de herbario de A. ingramii, las hojas son delgadas y de color verde amarillento, mientras las de A. argothamnoides son más gruesas y normalmente presentan tonalidades purpúreas. Morfológicamente estas tres especies forman un complejo que convendría explorar a detalle, pero cabe mencionar que según los análisis moleculares llevados a cabo hasta ahora (Ramírez-Amezcua, 2011), A. manzanilloana y A. argothamnoides no están cercanamente emparentadas, aunque no incluyen a $A$. ingramii.

Algunos ejemplares de esta especie habían sido determinados erróneamente como Argythamnia guatemalensis; sin embargo A. ingramii tiene estaminodios plumosos y los pétalos de las flores pistiladas son elípticos.

Ejemplares adicionales examinados: MÉXICO. QUINTANA ROO: [Mpio. José María Morelos], Chichankanab, Gaumer 1392 (CAS, F, GH, NY). SAN LUIS POTOSÍ: $8 \mathrm{mi} \mathrm{W}$ of Ebano toward Valles, Johnston 4507 (MEXU, MICH, TEX). TAMAULIPAS: ca. 91 road $\mathrm{km} \mathrm{N}$ of Cd. Victoria along hwy. 85, ca $13 \mathrm{~km} \mathrm{~S}$ of Villagran, Henrickson y Hess 19065 (TEX); $11 \mathrm{mi} \mathrm{N}$ of Soto La Marina on the road to Jiménez, Johnston y Crutchfield 4976 (TEX); $15 \mathrm{mi}$ from Tampico on the Mante hwy, Johnston y Graham 4083 (MICH, TEX); 7 mi S of Antiguo Morelos, Johnston y Graham 4567 (TEX); half mile E of Nuevo Morelos, Johnston y Graham 4483 A (TEX). VERACRUZ: Mpio. Jalcomulco, Cerro del Brujo, $3 \mathrm{~km}$ al N de Jalcomulco, Castillo-Campos y Zamora 8625 (XAL); Mpio. Emiliano Zapata, cerro con un torreón o pequeño fuerte en la cima, en Plan del Río, Cházaro, Oliva y Tapia 6065 (IBUG, XAL); $1.5 \mathrm{~km}$ antes de Méndez, yendo de Cacalilao, Chiang et al. 277 (GH, MEXU); Mpio. Paso de Ovejas, $2 \mathrm{~km} \mathrm{NE} \mathrm{de} \mathrm{Acazonica,}$ Medina y Vázquez 307 (MEXU, XAL); Baños del Carrizal, Purpus 6116 (F, GH, NY, UC); Actopan, Ventura 2764 (DS, ENCB, F, MICH, NY); Mpio. Dos Ríos, La Cumbre, Ventura 3920 (DS, ENCB, MICH, NY, TEX, XAL).

Argythamnia lanceolata (Benth.) Müll. Arg., Linnaea 34:148. 1865. Serophyton lanceolatum Benth., Bot. Voy. Sulphur. 52(-53). 1844. Aphora lanceolata (Benth.) Engelm. \& A.Gray, Pl. Lindheim. 1:25. 1845. Ditaxis lanceolata (Benth.) Pax \& K.Hoffm. in Engl., Das Pflanzeinreich IV. 147. VI [Heft 57]: 71. 1912. Tipo: México, Baja California Sur, Magdalena Bay, G. W. Barclay 3111 [holotipo K (no visto); isotipo BM (no visto), foto GH, RSA, UC].

Argythamnia sericophylla A.Gray ex S.Watson, Bot. California 2:70. 1880. Ditaxis sericophylla (A.Gray) A.Heller, Cat. N. Amer. Pl. 5. 1898. Tipo: México, Baja California, Sierra de Juárez, big cañon of the Tantillas, 18 sept. 1875, E. Palmer 446 (lectotipo GH, designado por Steinmann y Felger, 1997, p. 26.). 
Argythamnia sericophylla A.Gray ex S.Watson var. verrucosemina Millsp., Proc. Calif. Acad. Sci. ser. II, 2: 221(-222). 1889. Tipo: México, Baja California Sur, San Gregorio, 02 feb. 1889, T. S. Brandegee s.n. (holotipo F; isotipo UC).

Argythamnia palmeri S.Watson, Proc. Amer. Acad. Arts 24:77. 1889. Ditaxis palmeri (S.Watson) Pax. \& K.Hoffm. in Engl., Das Pflanzeinreich IV. 147. VI [Heft 57]: 64(-65). 1912. Tipo: México, Sonora, high in mountains above Guaymas, E. Palmer 247 [holotipo GH; isotipos MO, NY, $\mathrm{UC}$ (no visto), US].

Hierba perenne o subarbusto de hasta $1 \mathrm{~m}$ de alto, monoico o dioico, tallos ascendentes, estrigosos o estrigulosos, con cicatrices notorias en los nudos, corteza gris o amarillenta, fisurada, ramillas con ligeras líneas verticales, estrigosas o estrigulosas, grisáceas. Hojas con estípulas persistentes, subuladas, de 0.5 a $1.3 \mathrm{~mm}$ de largo, estrigosas; pecíolo corto, de 1 a $3 \mathrm{~mm}$ de largo, estrigoso; lámina lanceolada u ovada, de 1 a $4.5 \mathrm{~cm}$ de largo, de 0.4 a $1.4 \mathrm{~cm}$ de ancho, con 3 nervaduras basales, densamente estrigosa o estrigulosa; base decurrente; ápice agudo, mucronado o truncado; margen entero, rara vez aserrulado. Inflorescencias de 4 a $13 \mathrm{~mm}$ de largo, bisexuales o unisexuales, con una flor pistilada en la base (o solitaria) y de 2 a 9 flores estaminadas en la parte distal; brácteas ovadas o elípticas, de 1 a $2 \mathrm{~mm}$ de largo, de 0.6 a $1 \mathrm{~mm}$ de ancho, externamente seríceas, internamente glabras; margen entero. Flores estaminadas sobre pedicelos estrigosos, de 0.5 a $0.8 \mathrm{~mm}$ de largo; sépalos 5, lanceolados, de 2 a $3 \mathrm{~mm}$ de largo, de 0.5 a $0.8 \mathrm{~mm}$ de ancho, ápice agudo, margen entero, externamente estrigosos o seríceos, internamente glabros o estrigulosos; pétalos 5, elípticos, de 2.5 a $3.4 \mathrm{~mm}$ de largo, de 0.7 a $1.2 \mathrm{~mm}$ de ancho, base atenuada, ápice agudo, adnados a la columna estaminal, amarillentos, margen eroso y ciliado, externamente estrigosos hacia el centro, internamente glabros; estambres 10, dispuestos en 2 verticilos de 5 cada uno, columna estaminal de 1.5 a $2.5 \mathrm{~mm}$ de largo, la parte libre del filamento de 0.3 a $0.5 \mathrm{~mm}$ de largo, de 3 a 5 estaminodios, éstos reducidos o bien desarrollados, de 0.3 a $1 \mathrm{~mm}$ de largo; glándulas ovadas o subuladas, de 0.7 a $1 \mathrm{~mm}$ de largo, de 0.3 a 0.4 $\mathrm{mm}$ de ancho, glabras, amarillentas, ápice filiforme. Flores pistiladas sobre pedicelos estrigosos de $1 \mathrm{a} 1.5 \mathrm{~mm}$ de largo; sépalos 5, lanceolados, de 3 a $6.5 \mathrm{~mm}$ de largo, de 0.7 a $1.8 \mathrm{~mm}$ de ancho, ápice agudo, margen entero, externamente estrigosos, internamente seríceos o estrigosos; pétalos 5, elípticos, de 1.8 a $3 \mathrm{~mm}$ de largo, de 0.7 a $1.4 \mathrm{~mm}$ de ancho, base unguiculada, ápice agudo, amarillentos o purpúreos, margen eroso, ciliado o fimbriado, externamente estrigosos o seríceos, con los tricomas agregados en el centro, internamente glabros; ovario estrigoso-hispiduloso, estilos estrigosos o con un mechón de tricomas en el centro, de 1.5 a $2 \mathrm{~mm}$ de largo, libres de 0.7 a $2 \mathrm{~mm}$; estigmas aplanados, amarillentos; glándulas oblatas, elípticas u ovadas, de 0.4 a $1 \mathrm{~mm}$ de largo, de 0.5 a $0.7 \mathrm{~mm}$ de ancho, glabras o rara vez con tricomas (p.e. Carter y Chisaki 3632), amarillentas

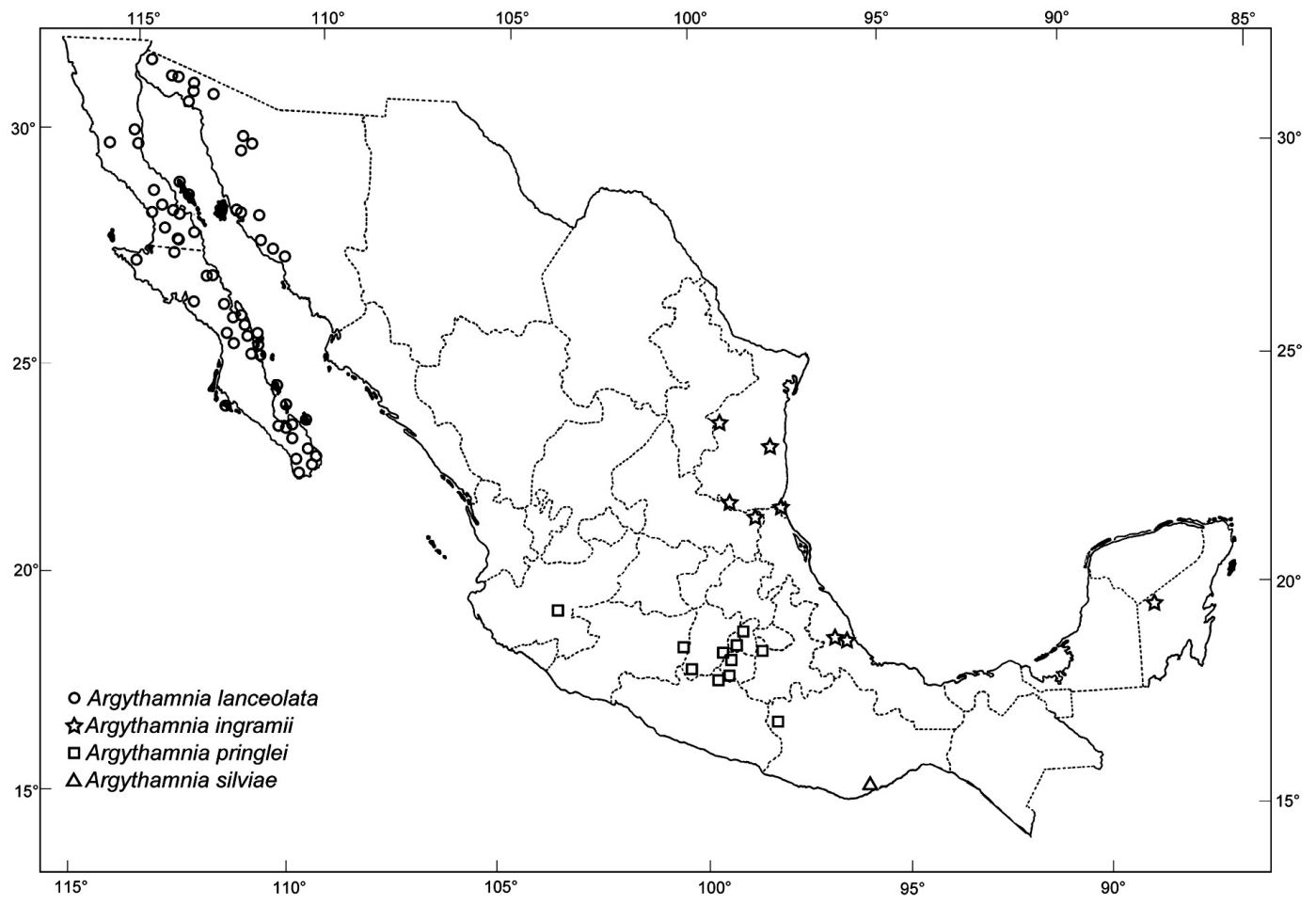

Figura 4. Distribución de Argythamnia lanceolata, A. ingramii, A. pringlei y A. silviae. 
o pardas, ápice obtuso o aristado. Cápsulas estrigoso-hispidulosas, de 3 a $4 \mathrm{~mm}$ de largo, de 3 a $5 \mathrm{~mm}$ de ancho, verdes o amarillentas. Semillas globosas, de 1.9 a $2.5 \mathrm{~mm}$ de largo, de 1.8 a $2.2 \mathrm{~mm}$ de ancho, base truncada, ápice agudo, grises o pardas, carúncula ausente, rafe notorio, superficie foveolada y ligera o fuertemente estriada y reticulada.

Distribución y ecología: En México se conoce de Baja California, Baja California Sur y Sonora (Figura 4); en Estados Unidos de América de Arizona y California. Crece en matorral xerófilo, a orilla de arroyos y caminos, en suelos arcillosos, arenosos, calcáreos y rocosos, en altitudes que van desde el nivel del mar hasta $700 \mathrm{~m}$. Florece y fructifica durante todo el año.

Argythamnia lanceolata es un subarbusto o hierba perenne común en el Desierto Sonorense. Es un taxón bien definido y se reconoce fácilmente por sus hojas lanceoladas, enteras (rara vez escasamente aserruladas) y densamente estrigosas (aunque algunas plantas que habitan cañones sombreados tienden a tener hojas más anchas y menos pubescentes), además de sus estigmas fuertemente aplanados y flores estaminadas con pétalos adnados al andróforo. Una colecta es interesante [Webster 19523 (MEXU)], ya que las flores estaminadas tiñen de rosado al mojarse.

Ejemplares adicionales examinados: MÉXICO. BAJA CALIFORNIA: $5 \mathrm{~km}$ NE of San Borja on road to Bahia de Los Angeles, Breedlove 60983 (CAS, TEX); Calamajue Canyon, Webster 18155 (MEXU, NY); Mesa slopes 1/2 km $\mathrm{N}$ of Forkin road to Rancho San Pedro, $29 \mathrm{mi} \mathrm{N}$ of Punta Prieta, Wiggins 15067 (DS, ENCB). BAJA CALIFORNIA SUR: Arroyo San Bruno, SE of Santa Rosalia, $4.8 \mathrm{mi} \mathrm{W}$ of hwy. 1 on rd to San Jose de Magdalena, Boyd y Ross 5838 (F, MEXU); Isla Danzante, south-facing above bay near north end of island, Carter y Sharsmith 4264 (MEXU, NY, UC); approaching Rancho La Presa, Wiggins 15485 (CAS, DS, GH, MEXU, TEX, UC). SONORA: Guaymas, Gentry 4677 (CAS, DS, F, GH, MEXU, MICH, MO, NY, UC); N end of Sierra El Viejo, in the large canyon containing the mina Santa Cruz, $25 \mathrm{mi} \mathrm{SW}$ of Caborca, Sanders et al. 3520 (MEXU, TEX); 9 mi N of Kino Bay, $1 \mathrm{mi}$ E of road, Spellenberg y Spellenberg 4958 (ENCB, MEXU, NY).

Argythamnia manzanilloana Rose, Contr. U. S. Natl. Herb. 1:357. 1895. Ditaxis manzanilloana (Rose) Pax \& K.Hoffm. in Engl., Das Pflanzenreich IV. 147. VI [Heft 57]: 59(-60). 1912. Tipo: México, Colima, Manzanillo, 01-31 dic. 1980, E. Palmer 1073 [holotipo US (no visto, se revisó una foto)].

Argythamnia gentryi J.W.Ingram, Bull. Torrey Bot. Club 80:421(-422). 1953. Ditaxis gentryi (J.W.Ingram) Radcl.Sm. \& Govaerts, Kew Bull. 52:479. 1997. Tipo: México,
Sinaloa, Cerro Tecomate, West of Pericos, $100 \mathrm{ft}$ (30 m), 29 feb. 1940, H. S. Gentry 5761 [holotipo UC; isotipos ARIZ, CAS (no visto), DS, MICH, NY, RSA].

Hierba perenne o subarbusto de hasta $1 \mathrm{~m}$, monoico, tallos ascendentes, frecuentemente con cicatrices notorias en lo nudos, corteza fisurada, grisácea o amarillenta, ramillas con ligeras líneas verticales, estrigosas o hispidulosas, verde-grisáceas. Hojas con estípulas persistentes, lanceoladas a subuladas, de 0.6 a $2.8 \mathrm{~mm}$ de largo, externamente estrigosas, internamente glabras, ápice agudo, margen entero; pecíolo acanalado, de 2 a $8 \mathrm{~mm}$ de largo, indumento igual al de las ramillas; lámina elíptica, de 0.5 a $6.7 \mathrm{~cm}$ de largo, de 0.3 a $3.5 \mathrm{~cm}$ de ancho, con 3 nervaduras basales, envés seríceo, estrigoso o hispiduloso, con los tricomas agregados en las nervaduras, haz estrigoso, estriguloso o hispiduloso; base aguda o cuneada; ápice agudo, a veces mucronado, con una excrecencia apical no específicamente glandular; margen aserrado, aserrulado, a veces entero o subentero con los dientes reducidos a una excrecencia esferoidal no específicamente glandular. Inflorescencias de 0.5 a $1.3 \mathrm{~cm}$ de largo, con una flor pistilada en la base y de 3 a 6 flores estaminadas en la parte distal; brácteas ovadas o elípticas, de 1 a $2 \mathrm{~mm}$ de largo, de 0.6 a $1.3 \mathrm{~mm}$ de ancho, externamente estrigosas o estrigulosas, internamente glabras; margen entero o fimbriado, frecuentemente amarillento. Flores estaminadas sobre pedicelos estrigosos o hispidulosos, hasta de $0.2 \mathrm{~mm}$ de largo; sépalos 5, elípticos, de 2 a $3 \mathrm{~mm}$ de largo, de 0.5 a $1 \mathrm{~mm}$ de ancho, ápice agudo, margen entero, amarillento, externamente seríceos, estrigosos o lanulosos, internamente glabrescentes en la base y estrigosos en el ápice; pétalos 5, elípticos a lanceolados, de 1.5 a $3.3 \mathrm{~mm}$ de largo, de 0.5 a 1 $\mathrm{mm}$ de ancho, base recta a ligeramente atenuada, ápice agudo, adnados a la columna estaminal, amarillentos, rosados o rojizos, margen entero, ondulado o ciliado, externamente estrigosos, con los tricomas agregados en el centro, internamente glabros; estambres 10, dispuestos en 2 verticilos de 5 cada uno, columna estaminal rojiza o amarillenta, generalmente exerta de la corola, de 1.7 a $3.5 \mathrm{~mm}$ de largo, la parte libre del filamento de 0.2 a $0.5 \mathrm{~mm}$ de largo, 4 o 5 estaminodios filiformes, de 0.2 a $1 \mathrm{~mm}$ de largo, plumosos; glándulas ovadas, elípticas o eventualmente trilobadas, de 0.2 a 0.4 $\mathrm{mm}$ de largo, de 0.2 a $0.5 \mathrm{~mm}$ de ancho, glabras, amarillentas, blanquecinas o pardas, ápice agudo u obtuso. Flores pistiladas sobre pedicelos seríceos o estrigosos hasta de 0.7 de largo; sépalos 5, angostamente elípticos o lanceolados, de 1.5 a $4.7 \mathrm{~mm}$ de largo, de 0.5 a $1.3 \mathrm{~mm}$ de ancho, ápice agudo, margen entero, amarillentos, externamente seríceos o estrigosos, internamente seríceos o estrigosos hacia el ápice y glabros en la base; pétalos 5, elípticos a romboides, de 1.5 a $3 \mathrm{~mm}$ de largo, de 0.6 a $1 \mathrm{~mm}$ de ancho, base clavada, ápice agudo, amarillentos o rosados, margen entero, ciliado, externamente estrigosos, internamente glabros; ovario seríceo, estrigoso o hispiduloso, estilos estrigosos, de 1.2 a 2.5 
$\mathrm{mm}$ de largo, libres de 0.5 a $1 \mathrm{~mm}$, rojizos o amarillentos; estigmas aplanados, a veces muy ligeramente aparentando ser rollizos, rojizos o amarillentos; glándulas elípticas, ovadas u oblatas, de 0.2 a $0.5 \mathrm{~mm}$ de largo, de 0.3 a $0.4 \mathrm{~mm}$ de ancho, glabras, amarillentas, ápice generalmente obtuso, a veces agudo o hendido, margen entero, a veces ondula- do. Cápsula de 2.5 a $4 \mathrm{~mm}$ de largo, de 3 a $4.3 \mathrm{~mm}$ de ancho, serícea o hispidulosa Semillas globosas, de 2 a 2.4 $\mathrm{mm}$ de largo, de 1.7 a $2 \mathrm{~mm}$ de ancho, base redondeada o escasamente truncada, ápice apiculado, grisáceas o pardas, carúncula ausente, rafe frecuentemente evidente, superficie estriada, punteada o reticulada.

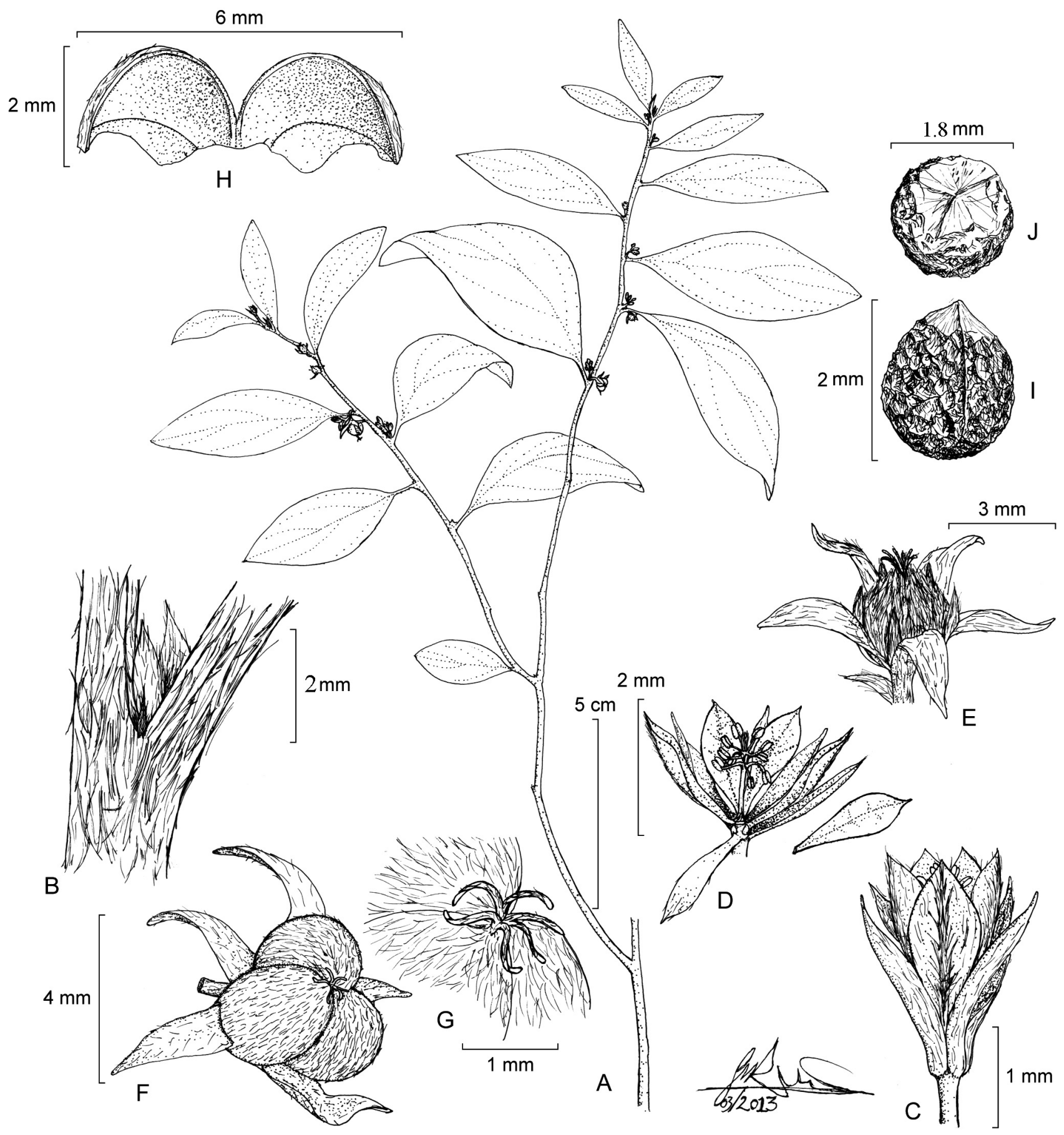

Figura 5. Argythamnia ingramii Y.Ramírez-Amezcua y V.W.Steinm. A. Hábito. B. Nudo con una estípula y la yema. C. Flor estaminada. D. Flor estaminada con un pétalo removido. E. Flor pistilada. F. Fruto. G. Detalle mostrando los estilos. H. Apariencia de un lóculo después de la dehiscencia. I. Semilla, vista dorsal. J. Semilla, vista apical. 
Distribución y ecología: Endémica de la vertiente Pacífico de México; se encuentra en Colima, Guerrero, Jalisco, Michoacán, Nayarit, Oaxaca, Sinaloa y Sonora (Figura 6). Crece en bosque tropical caducifolio, matorral xerófilo, pastizal y dunas costeras; en suelos arenosos, arcillosos, calizos y pedregosos, desde el nivel del mar hasta 1,300 m. Florece $\mathrm{y}$ fructifica durante casi todo el año.

Nombres comunes: histomicha, tacotillo.

Argythamnia manzanilloana puede confundirse con $A$. ingramii, la especie morfológicamente más cercana (ver discusión bajo A. ingramii). Ejemplares de esta especie frecuentemente se determinan erróneamente como A. guatemalensis; sin embargo, A. manzanilloana se distingue fácilmente por el androceo generalmente exerto de la corola, los estaminodios plumosos y las flores pistiladas con pétalos elípticos a romboides, notoriamente adelgazados en la base; mientras A. guatemalensis tiene el androceo siempre inserto en la corola, los estaminodios glabros y las flores pistiladas con pétalos lanceolados a lineares.

Dos colectas tienen la apariencia general de Argythamnia manzanilloana, pero no presentan estaminodios plumosos. La primera, proviene de Sonora [Arroyo El Mentidero, at El Chinal road, $11.3 \mathrm{~km} \mathrm{~S}$ of Álamos, Van Devender et al. 92-1034 (IEB)], tiene el androceo ligeramente exerto y estaminodios bien desarrollados pero glabros; además, la unión de los estilos forma una columna corta y los pétalos en las flores pistiladas son lanceolados. La otra colecta es de un lugar relativamente cercano en el norte de Sinaloa [Río Fuerte, "Calmoa", mezquite dry arroyo, Gentry $941 \mathrm{~m}$ (MICH)], en la cual androceo está inserto en la corola y no hay estaminodios; sin embargo, el material es joven e insuficiente para determinarlo con certeza. Más colectas del sur de Sonora y del norte de Sinaloa pueden aclarar el estatus de este morfo.

Ejemplares adicionales examinados: MÉXICO. COLIMA: steep hills with occasional rock-outcrops, ca $14 \mathrm{mi}$ WNW of Santiago, road to Cihuatlán Jalisco, McVaugh 20777 (CAS, IEB, MEXU, MICH); $2 \mathrm{~km}$ al E del Río Armería, Sanders 11927 (CAS); Santiago Beach, $12 \mathrm{~km}$ E of Manzanillo, West 3507 (GH, UC). GUERRERO: Acapulco and vicinity, Palmer 11 (CAS, F, NY, UC, US). JALISCO: Mpio. Puerto Vallarta, camino a la Palapa entre San Nicolás y la Palapa, (Las Peñas), Castillo, Zamora y Acevedo 10011 (MEXU); 5 $\mathrm{km}$ al W de Chamela, Iltis y Nee 1574 (IBUG, NY); Cabo Corrientes, camino que sale de la telesecundaria al cerro El Vigía por el camino a la mina, al N de Villa del Mar, Ramírez-Delgadillo y Espíndola 5705 (IBUG). MICHOACÁN: Mpio. Pómaro, al N de Maruata, camino a Pómaro, Guevara 1614 (ENCB, IBUG); 3-6 km SE of San Juan de Lima, nearly S of Coahuayana, McVaugh 22998 (CAS, ENCB, IEB, MEXU, MICH); Mpio. Aguililla, $7.5 \mathrm{~km}$ por el camino a Apatzingán, Ramírez-Amezcua, Steinmann y Carranza 352 (IEB). NAYARIT: Islas Tres Marías, María Madre, radio station, Mason 1790 (CAS, US). OAXACA: Distr. Tehuan-

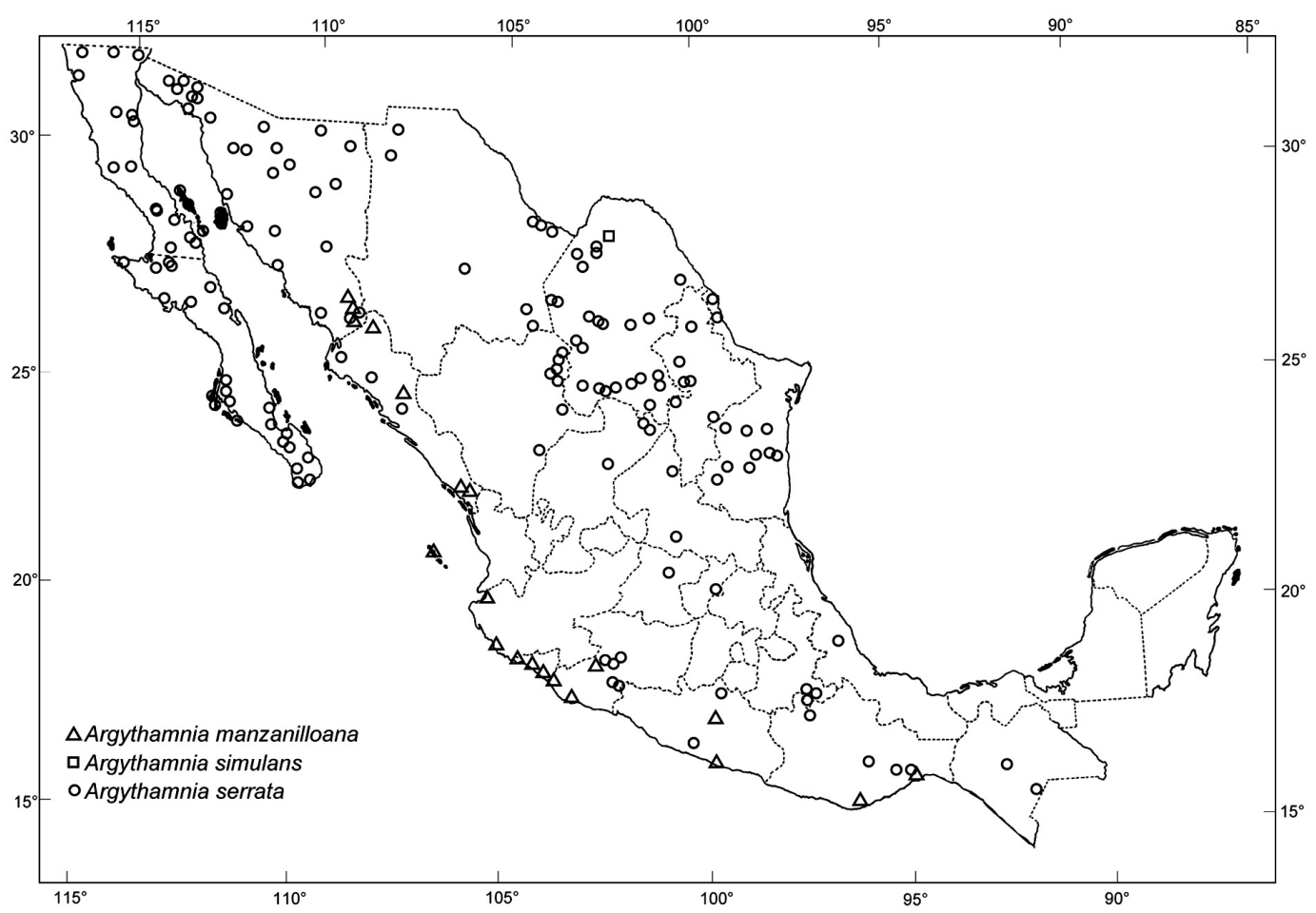

Figura 6. Distribución de Argythamnia manzanilloana, A. simulans y A. serrata. 
tepec, Mpio. Santo Domingo Tehuantepec, Guelaguichi, entronque de la autopista, Elorsa 7230 (SERO); Tehuantepec, Matuda 91 (MEXU, US); Distr. Pochutla, Mpio. San Miguel del Puerto, Puente Zimatán, 12.8 km de la desviación, por la brecha hacia Xadani, Rivera et al. 1997 (SERO). SINALOA: cercanías de Guadalupe, Rose, Standley y Russell 14710 (NY, US); $6 \mathrm{~km}$ al NE de Matatán, Tenorio et al. 8502 (MEXU); Mpio. Mazatlán, entre Villa Unión y Concordia, Vega, Vega y López 2849 (ENCB, MEXU). SONORA: San Bernardo, Río Mayo, Gentry 1292 (MICH); Arroyo Gochico, $11 \mathrm{~km}$ (by air) W of San Bernardo, and $1.5 \mathrm{~km} \mathrm{~W}$ of Gochico Viejo, Steinmann et al. 604 (NY, TEX); Arroyo El Mentidero, at El Chinal road, $11.3 \mathrm{~km} \mathrm{~S}$ of Álamos, Van Devender y Van Devender 92-1041 (IEB).

Argythamnia pringlei Greenm., Proc. Amer. Acad. Arts 41:238. 1905. Ditaxis pringlei (Greenm.) Pax \& K.Hoffm. En Engl., Das Pflanzenreich IV. 147. VI [Heft 57]: 66. 1912. Tipo: México, Morelos, sides of a barranca near Cuernavaca, 5,000 ft (1,524 m), 17 jun. 1904, C. G. Pringle 8819 (holotipo GH; isotipos UC, MO, NY, US).

Arbusto o subarbusto de hasta $2.5 \mathrm{~m}$ de alto, monoico, tallos erectos, estrigosos o seríceos, corteza grisácea, fisurada, ramillas angulosas por ligeras líneas verticales, estrigosas o seríceas, verdosas o grisáceas. Hojas con estípulas inconspicuas, caedizas, subuladas, de 0.3 a $1.8 \mathrm{~mm}$ de largo, seríceas, margen entero; pecíolo acanalado, de 3 a $6 \mathrm{~mm}$ de largo, indumento igual al de las ramillas; lámina ovada o elíptica, a veces asimétrica, de 1.4 a $11.7 \mathrm{~cm}$ de largo, de 1.5 a $6 \mathrm{~cm}$ de ancho, con 3 o 5 nervaduras suprabasales, envés pilosuloso, lanuloso o glabrescente, haz seríceo, lanoso o lanuloso; base obtusa, decurrente o cóncava; ápice agudo, acuminado, mucronado, rara vez pilífero o emarginado; margen aserrado, aserrulado o subentero, con los dientes papilados. Inflorescencias de 2.5 a $9.5 \mathrm{~cm}$ de largo, con una flor pistilada en la base, rara vez 2, de 3 a 13 flores estaminadas en la parte distal; brácteas lanceoladas o angostamente elípticas, de 2 a $7 \mathrm{~mm}$ de largo, de 0.7 a $1.5 \mathrm{~mm}$ de ancho, externamente seríceas o pilosulosas, internamente glabras, ápice agudo; margen aserrulado o entero. Flores estaminadas sobre pedicelos estrigosos de 0.5 a $1.3 \mathrm{~mm}$ de largo; sépalos 5, lanceolados, de 3.3 a $6 \mathrm{~mm}$ de largo, de 0.9 a 1.9 $\mathrm{mm}$ de ancho, ápice agudo, margen entero, externamente seríceos, internamente glabros; pétalos 5, espatulados, cuculados, de 2 a $3 \mathrm{~mm}$ de largo, de 0.5 a $1.6 \mathrm{~mm}$ de ancho, base clavada, ápice mucronado, obtuso o redondeado, libres de la columna estaminal, blancos, amarillentos o rosados, margen ondulado, eroso o entero, externamente estrigosos en la parte media, internamente glabros; estambres 10, dispuestos en 2 verticilos de 5 cada uno, columna estaminal robusta, de 1.1 a $2.6 \mathrm{~mm}$ de largo, de 0.2 a $1.6 \mathrm{~mm}$ de ancho, amarillenta o purpúrea, la parte libre del filamento de 0.3 a $0.7 \mathrm{~mm}$ de largo, estaminodios ausentes o de 3 a 5 cuan- do presentes, de 0.2 a $3 \mathrm{~mm}$ de largo; glándulas elípticas a oblatas, de 0.3 a $0.6 \mathrm{~mm}$ de largo, de 0.3 a $0.7 \mathrm{~mm}$ de ancho, glabras, amarillentas, ápice obtuso, margen ondulado o entero. Flores pistiladas sobre pedicelos seríceos o estrigosos de 1.5 a $5 \mathrm{~mm}$ de largo; sépalos 5 , ovados, de 5 a $6.9 \mathrm{~mm}$ de largo, de 1.7 a $3.4 \mathrm{~mm}$ de ancho, ápice agudo, margen entero $\mathrm{o}$ aserrulado, externamente estrigosos, internamente estrigulosos; pétalos 5, reducidos, fliliformes a espatulados, de 0.5 a $2.7 \mathrm{~mm}$ de largo, de $0.1 \mathrm{a} 1.1 \mathrm{~mm}$ de ancho, base clavada, ápice agudo a obtuso, blancos o amarillentos, margen eroso, externamente glabrescentes, seríceos o estrigulosos, con los tricomas agregados en el centro, internamente glabrescentes o glabros; ovario seríceo o hispiduloso, estilos estrigosos o glabrescentes con un mechón de tricomas en el centro, de 0.9 a $2.6 \mathrm{~mm}$ de largo, libres de 0.4 a $1.3 \mathrm{~mm}$, purpúreos o grisáceos; estigmas aplanados, amarillentos o purpúreos, margen eroso o entero; glándulas oblatas, de 0.3 a $0.8 \mathrm{~mm}$ de largo, de 0.5 a $0.7 \mathrm{~mm}$ de ancho, glabras, amarillentas, ápice generalmente obtuso, a veces agudo o retuso, margen ondulado. Cápsulas seríceas, de 6 a $11 \mathrm{~mm}$ de largo, de 8.7 a $14 \mathrm{~mm}$ de ancho, grisácea. Semillas ovoides, de 5 a 7 $\mathrm{mm}$ de largo, de 4 a $6.5 \mathrm{~mm}$ de ancho, base truncada, ápice apiculado, negruzcas o pardas, carúncula ausente, rafe evidente, con una cicatriz apical circular o linear de 1 a $3.5 \mathrm{~mm}$ de largo, blanquecina, superficie rugosa, ligeramente reticulada, a veces con ligeras excrecencias.

Distribución y ecología: Endémica de México; se encuentra en el Distrito Federal, Guerrero, Jalisco, México, Michoacán, Morelos, Oaxaca y Puebla (Figura 4). Crece en bosque de encino, encino-pino y matorral xerófilo en suelos rocosos y ricos en materia orgánica; en elevaciones que van desde 1,400 hasta $2,500 \mathrm{~m}$. Florece y fructifica de mayo a diciembre.

Greenman (1905) propuso Argythamnia pringlei con base en una colecta de Morelos. Diferenció esta especie de A. heterantha por tener flores estaminadas con pétalos ovados, hojas con nervaduras laterales más divergentes y ovario densamente pubescente. Pax y Hoffmann (1912) ubicaron estas dos especies en diferentes secciones, pero solamente examinaron el material tipo de A. pringlei y ninguna colecta de A. heterantha. La sección Calycanthae Pax \& K.Hoffm. incluye a $A$. heterantha y algunas especies de Sudamérica y las Antillas. Se caracteriza por tener flores pistiladas con cáliz semiaperturado petagonal y sépalos con margen subrecurvado, acrescentes después de la antesis, mientras que $A$. pringlei y algunas especies de Norteamérica conforman la sección Serophyton (Benth.) Baill., caracterizada por cáliz semiaperturado cilíndrico y sépalos con margen plano, no acrescentes después de la antesis. Al menos en el caso de estas dos especies, los caracteres que diferencian a las secciones parecen carecer de valor taxonómico. No ha sido posible reconocer la acrescencia del cáliz post antesis, y aunque la 
forma del cáliz pueda servir para diferenciar las especies en fresco, este carácter no se conserva en los ejemplares de herbario, por lo que no es útil. Por su parte, Ingram en sus tesis de doctorado (1956) estableció la sección Pseudoaphora para A. heterantha y A. pringlei pero nunca la publicó formalmente. Este grupo se caracteriza por el hábito arbustivo, inflorescencias elongadas y pedicelos de las flores pistiladas de 7 a $10 \mathrm{~mm}$ de largo. Aunque su trabajo no incluye datos sobre la diferenciación a nivel específico, su clasificación sí representa la afinidad entre ambas especies.

Como se mencionó anteriormente, Argythamnia prinlei y A. heterantha son morfológicamente similares. En el estudio molecular de Ramírez-Amezcua (2011) resultan hermanas, por lo que puede afirmarse que son entidades estrechamente relacionadas. Se conciben aquí como especies distintas, aunque A. pringlei podría considerarse bajo $A$. heterantha, dado que el único carácter que las diferencia es la pubescencia del ovario. Las cápsulas de A. pringlei son densamente pubescentes en todas las etapas del desarrollo, mientras que las de A. heterantha generalmente son glabras (a veces presentan tricomas malpigiáceos dispersos y caedizos en los ovarios jóvenes, pero tienden a desaparecer al madurar la cápsula). No hay diferencias significativas en la forma de los pétalos de las flores pistiladas (como mencionó Greenman cuando describió A. pringlei), que en ambas especies son espatulados. Las hojas de A. pringlei son coriáceas, anchamente elípticas a circulares, mientras que en general $A$. heterantha tiene hojas de menor tamaño, membranáceas y lanceoladas, pero también puede tenerlas coriáceas y anchamente elípticas, idénticas a las de A. pringlei; el grado de divergencia de las nervaduras laterales depende directamente de la forma y el tamaño de la hoja. El arreglo de los diez estambres en dos verticilos es notorio, aunque en ocasiones estos son muy cercanos, y la presencia de estaminodios (hasta cinco) varía en las dos especies, pero es más común en A. pringlei. Las semillas de ambas especies son muy similares y aunque no se conoce ningún uso para las de A. pringlei, tal vez compartan algunas propiedades.

Ejemplares adicionales examinados: MÉXICO. DISTRITO FEDERAL: cerca de Tlatenco, Delegación Tláhuac, entre campos cultivados, Rzedowski 37304 (ENCB, GH, IBUG, IEB, MEXU, MO, NY); base de la Sierra de Santa Catarina, al N de Tlaltenco, Delegación Tláhuac, Rzedowski 37466 (ENCB, F, GH, IBUG, IEB, MEXU, MO, NY); San Francisco Tlaltenco, Delegación Tláhuac, Ventura 3794 (ENCB, IEB, MEXU, MO, NY, XAL). GUERRERO: Mpio. Taxco, $7 \mathrm{~km}$ al SE de Taxco, Camino Iguala-Taxco, Martínez y Soto 1221 (MEXU). JALISCO: Mpio. Tuxcueca, Cerro de García, subiendo por el Sauz, Machuca y Cházaro 6666 (IEB, MO); Mpio. Tuxcueca, cara noreste del Cerro de García, subiendo por El Sauz, Ramírez-Amezcua, Rocha-Loredo y Machuca 656 (IEB). MÉXICO: Distr. Temascaltepec, Tejupilco, Hinton et al. 5413 (LL, MICH, NY); Lagunas de
Zempoala, Lyonnet 521100024 (CAS, MEXU, MO); Santa Catarina, Smith 5093 (US). MICHOACÁN: Mpio. Zitácuaro, ladera oeste del Cerro Enandio, $1.5 \mathrm{~km}$ al S de Coyota, al E de los huertos de guayaba en El Tizate, RamírezAmezcua y Steinmann 513 (IEB); Mpio. Zitácuaro, Cerro Enandio, $2 \mathrm{~km}$ al S de Coyota, hacia Tizate, $26 \mathrm{~km}$ al S de Zitácuaro, Torres y Ramírez 13654 (IEB, MEXU, MICH, XAL). MORELOS: Tetela de Monte, Cuernavaca, Lyonnet 550800018 (MEXU); Lomas de Atzingo, Cuernavaca, Lyonnet 500800013 (MEXU); Sierra de Calchi (Chalchi), cerca de Tepoztlán, Paray 1602 (ENCB); cerca de Cuernavaca, Rose, Painter y Rose 10216 (GH, MEXU, US). OAXACA: Distrito de Sola de Vega, El Vado, camino a las Grutas de San Sebastián, Cedillo y Torres 1743 (F, MEXU); Oaxaca, Conzatti 4654 (MICH); Mpio. Justlahuaca, cañada de las estrellas, al E de S. Naranjas, Zamudio y Ocampo 10944 (IEB). PUEBLA: Mpio. San Nicolás de los Ranchos, camino al cerro Teotón, lado oriente San Pedro Yancuictlapan, Tlapa y Ubierna 829 (IEB).

Argythamnia serrata (Torr.) Müll.Arg., Linnaea 34:147. 1865. Aphora serrata Torr., Botany of the Boundary, [in Emory, Rep. U.S. Mex. Bound. 2, pt. 1]: 197. 1858. Ditaxis serrata (Torr.) A.Heller, Cat. N. Amer. Pl. 5. 1898. Tipo: Estados Unidos de América, California, (la etiqueta dice Sonora) sand flats near Fort Yuma, ene. 1855, Schott $s . n$. (lectotipo NY; isolectotipo NY, designado por Steinmann y Felger 1997, p. 27).

Argythamnia neomexicana Müll.Arg., Linnaea 34:147. 1865. Ditaxis neomexicana (Müll.Arg.) A.Heller, Cat. N. Amer. Pl. 5. 1898. Tipo: Estados Unidos de América, New Mexico, Upper Río Grande, 1851-25, C. Wright 1797 [sintipo G (no visto); isosintipo MO]; Estados Unidos de América, Western Texas to El Paso, New México, may.-oct. 1849. C. Wright 643 [sintipo G (no visto); isosintipo NY, MO].

Argythamnia serrata (Torr.) Müll.Arg. var. magdalenae Millsp., Proc. Calif. Acad. Sci., II, 2: 221. 1889. Ditaxis serrata (Torr.) A.Heller var. magdalenae (Millsp.) Eastw., Proc. Calif. Acad. Sci. ser. IV, 18:479. 1929. Tipo: México, Baja California Sur, Isla Magdalena, 13 jun. 1889, T. S. Brandegee s.n. (holotipo F).

Ditaxis odontophylla Rose \& Standl., Contr. U. S. Natl. Herb. 16:12. 1912. Tipo: México, Sonora, Puerto Peñasco, Papago Tanks (Pinacate region), 14 nov. 1908, D. T. McDougal 36 (holotipo US; foto del holotipo F, GH).

Argythamnia californica Brandegee, Zoe 5:230. 1906. Ditaxis californica (Brandegee) A.Heller, Mulhenbergia 8:60. 1912. Ditaxis serrata (Torr.) A.Heller var. californica (Brandegee) V.W.Steinm. \& Felger, Madroño 42(4):456(-457). 1995. Tipo: Estados Unidos de América, California, River- 
side County, Colorado Desert, Marshall Canyon, seven mi west of Coachella, north of base of El Toro Mountain, 1000 $\mathrm{ft}$ (304 m), apr.1905, H. M. Hall 5796 [holotipo UC; isotipos GH, POM (no visto)].

Argythamnia gracilis Brandegee, Zoe 5:242(-243). 1908. Tipo: México, Sinaloa, near Culiacán, 14 sept. 1904, T. S. Brandegee s.n. (holotipo UC).

Ditaxis gracilis Rose \& Standl., Contr. U. S. Natl. Herb. 16:12(-13). 1912. Tipo: México, Sonora, Guaymas, 1887, E. Palmer 624 [holotipo US (no visto, se revisó una foto); isotipo NY].

Argythamnia micrandra Croizat, J. Arnold. Arbor. 26:191. 1945. Ditaxis micrandra (Croizat) Radcl.-Sm. \& Govaerts, Kew Bull. 52:479. 1997. Tipo: México, Guerrero, Coyuca, Cutzamala, 18 jul. 1934, G. B. Hinton et al. 6307 [holotipo GH; fragmento del holotipo A; isotipos MICH, NY, US (no visto)].

Argythamnia dressleriana J.W.Ingram, Bull. Torrey Bot. Club 80:422(-423). 1953. Ditaxis dressleriana (J.W.Ingram) Radcl.-Sm. \& Govaerts, Kew Bull. 52:479. 1997. Tipo: México, Puebla, vicinity of San Luis Tuiltitlanapa, near Oaxaca, ago. 1908, C. A. Purpus s.n. (holotipo UC).

Argythamnia serrata (Torr.) Brandegee, Proc. Calif. Acad. Sci. II, 3:173. 1891. nom. illeg., non A. serrata (Torr.) Müll. Arg., 1866. El nombre "Argythamnia serrata Brandegee" ha sido citado por diferentes autores y este binomio también se encuentra en Tropicos como un nomen illegitimum. Sin embargo, Brandegee solamente cita una de sus colectas que pertenecen a este taxón y dice "Argythamnia serrata (Torr.)". Dado que 25 años antes Müller realizó la combinación formal en Argythamnia para esta especie, la de Brandegee es superflua.

Hierba anual o perenne, hasta de $50 \mathrm{~cm}$ de alto, monoica, tallos erectos a postrados, pubescentes o rara vez completamente glabros, a veces con cicatrices notorias en los nudos, corteza grisácea o amarillenta, ramillas con ligeras líneas verticales, estrigosas o seríceas, con tricomas malpigiáceos plateados o dorados. Hojas con estípulas inconspicuas, caedizas, ovadas, lanceoladas o subuladas, de 0.5 a $2.3 \mathrm{~mm}$ de largo, estrigosas; pecíolo ausente o de hasta $10 \mathrm{~mm}$ de largo, indumento igual al de las ramillas; lámina elíptica, ovada, obovada o angostamente lanceolada, de 1 a $10.5 \mathrm{~cm}$ de largo, de 0.2 a $3 \mathrm{~cm}$ de ancho, verde o eventualmente rojiza, con 3 nervaduras en la base, envés seríceo o estrigoso, frecuentemente con tricomas de diferente longitud y grosor, haz seríceo, estrigoso, estriguloso o glabrescente; base atenuada; ápice agudo no específicamente glandular, obtuso, mucronado, rara vez obcordado; margen aserrado, aserrulado, subentero o entero, los dientes con una excre- cencia esferoidal, no específicamente glandular. Inflorescencias de 0.4 a $1.5 \mathrm{~cm}$ de largo, con una flor pistilada en la base y de 2 a 4 flores estaminadas en la parte distal; brácteas ovadas o elípticas, de 0.8 a $2 \mathrm{~mm}$ de largo, de 0.2 a 1 $\mathrm{mm}$ de ancho, verdes o amarillentas, a veces rojizas hacia el centro, externamente estrigosas, estrigulosas o hispidulosas, internamente glabras; margen ondulado, aserrulado o ciliado. Flores estaminadas sobre pedicelos estrigosos, glabrescentes o glabros de 0.3 a $1.3 \mathrm{~mm}$ de largo; sépalos 5 , lanceolados, de 0.9 a $2.5 \mathrm{~mm}$ de largo, de 0.4 a $1.4 \mathrm{~mm}$ de ancho, ápice agudo, margen entero, externamente seríceos, estrigosos o hispidulosos, internamente glabros; pétalos 5, elípticos a obovados, de 1.5 a $3.5 \mathrm{~mm}$ de largo, de 0.6 a 2 $\mathrm{mm}$ de ancho, base atenuada, ápice agudo, a veces pilífero, libres de la columna estaminal, amarillentos, blancos, a veces ligeramente rosados en la parte media, margen ondulado o eroso, externamente estrigulosos o glabros, internamente glabros; estambres 10, dispuestos en dos verticilos de 5 cada uno, columna estaminal de 0.7 a $1.7 \mathrm{~mm}$ de largo, la parte libre del filamento de 0.1 a $0.5 \mathrm{~mm}$ de largo, estaminodios ausentes o de 3 a 5 cuando presentes, de 0.1 a 0.7 mm de largo; glándulas elípticas a oblongas, de 0.3 a 0.5 $\mathrm{mm}$ de largo, de 0.1 a $0.2 \mathrm{~mm}$ de ancho, glabras, amarillentas, ápice obtuso o agudo. Flores pistiladas sobre pedicelos estrigoso-hispidulosos de 0.7 a $2 \mathrm{~mm}$ de largo; sépalos 5 , lanceolados o elípticos, de 2.3 a $6.5 \mathrm{~mm}$ de largo, de 0.6 a $1.6 \mathrm{~mm}$ de ancho, ápice agudo, margen aserrulado, entero o ciliado, blanquecino o amarillento, externamente estrigosos, frecuentemente con tricomas de diferente grosor y longitud, internamente estrigulosos o glabros; pétalos 5, elípticos, de 0.7 a $3 \mathrm{~mm}$ de largo, de 0.4 a $1.6 \mathrm{~mm}$ de ancho, base unguiculada, ápice agudo, amarillentos, a veces rosados, margen ondulado, entero, eroso o ciliado, externamente seríceos o estrigosos, con los tricomas agregados en el centro, internamente glabros o glabrescentes; ovario seríceo, estrigoso, frecuentemente con tricomas de diferente grosor y longitud, estilos con un mechón de tricomas en el centro, de 1 a 1.8 $\mathrm{mm}$ de largo, libres de 0.7 a $1.4 \mathrm{~mm}$, rojizos o amarillentos; estigmas rollizos, rojizos o amarillentos; glándulas elípticas, de 0.4 a $0.6 \mathrm{~mm}$ de largo, de 0.3 a $0.4 \mathrm{~mm}$ de ancho, glabras, amarillentas, ápice obtuso, margen entero, ciliado o fimbriado. Cápsulas de 1.8 a $3 \mathrm{~mm}$ de largo, de 2.7 a $4.5 \mathrm{~mm}$ de ancho, estrigoso-hispidulosas, trilobadas o rara vez tetralobadas, verde-grisáceas. Semillas globosas u ovoides, de 2 a $2.4 \mathrm{~mm}$ de largo, de 1.5 a $1.8 \mathrm{~mm}$ de ancho, base redondeada o truncada, ápice apiculado, grisáceas, pardo-rojizas, carúncula ausente, rafe a veces evidente, a veces con una cicatriz apical crateriforme de 0.2 a $1.5 \mathrm{~mm}$ de largo, blanquecina, superficie lisa, granulosa, punteada, ligera a fuertemente estriada o reticulada. Número cromosómico: N = 13 II.

Distribución y ecología: Desde Estados Unidos de América (en Arizona, California, New Mexico, Texas y sur de Nevada) hasta Guatemala; en México se encuentra en Baja Ca- 
lifornia, Baja California Sur, Chiapas, Chihuahua, Coahuila, Durango, Guanajuato, Guerrero, Michoacán, Oaxaca, Puebla, Querétaro, San Luis Potosí, Sinaloa, Sonora, Tamaulipas, Zacatecas y Veracruz (Figura 6). Crece en bosque tropical caducifolio, matorral xerófilo, dunas costeras y eventualmente en campos de cultivo; en suelos arenosos arcillosos, calcáreos y rocosos, desde el nivel del mar hasta 2,200 m. Florece y fructifica durante todo el año. Flores visitadas por avispas y pequeñas abejas.

Nombre común: cualilla.

Argythamnia serrata es la especie mexicana más ampliamente distribuida. Muestra una amplitud de variación morfológica y su complejidad se evidencia por las seis especies y una variedad que han sido descritas para describirla (Argythamnia californica, A. dressleriana, A. gracilis, A. micrandra, A. neomexicana, A. serrata var. magdalenae y Ditaxis odontophylla). Como se argumenta a continuación, estas entidades son morfológicamente inseparables y es preferible reconocerlas dentro de una especie polimórfica.

Torrey (1858) citó dos especímenes en el protólogo de Aphora serrata. Uno de ellos (Schott s.n.) fue designado como lectotipo (Steinmann y Felger, 1997). El otro (Parry s.n.) corresponde a lo que se ha reconocido como Argythamnia neomexicana, una especie descrita por Müller (1865). En el protólogo de A. neomexicana (Müller, 1865) no se establecieron las afinidades con A. serrata, pero posteriormente (Müller, 1866) fueron agrupadas (con A. montevidensis, una especie de Sudamérica) en un taxon sin rango dentro de la sección Aphora. Según las descripciones de este trabajo, A. neomexicana se distingue de A. serrata por los siguientes rasgos: (1) hojas enteras, lanceolado-obovadas, lanceoladas o linear-lanceoladas, agudas, con la base angosta, de 1.5-2.5 cm de largo (vs. hojas denticulado-serradas, ovadas, oblongo-elípticas, obtusas o agudas, con la base atenuada, de $2-2.5 \mathrm{~cm}$ de largo), (2) flores estaminadas con pétalos espatulados ( $v s$. pétalos rombóicos-lanceolados),y (3) semillas tuberculado-ásperas ( $v s$. corrugadas). Otros autores han diferenciado estas especies con distintos caracteres, por ejemplo Webster (1993) distinguió las plantas con semillas redondeadas en sección tranversal, hojas elípticas densamente pilosas y claramente dentadas, como A. serrata y las de semillas angulosas, hojas lanceoladas, no densamente pilosas y ligeramente dentadas como A. neomexicana. Por otro lado, Wiggins (1964) separó A. serrata de A. neomexicana por el tamaño de los sépalos de las flores pistiladas (2.5 hasta $3 \mathrm{~mm} v s .5-6 \mathrm{~mm}$ de largo) y la ornamentación de la semilla (ligeramente reticuladas a lisas vs. fuertemente reticulado-foveoladas). Posteriormente Steinmann y Felger (1997) analizaron más a detalle este complejo de especies y definieron como A. serrata s.s. a plantas robustas que crecen en suelos arenosos con hojas obovado-espatuladas, ápice obtuso a truncado y tricomas de diferente grosor en el envés, y por otro lado ubicaron las plantas con hojas ovado- elípticas con ápice rostrado y tricomas de grosor uniforme como A. neomexicana.

A pesar de que las diferencias mencionadas anteriormente resultan válidas para distinguir Argythamnia neomexicana de A. serrata, ninguna las separa claramente ya que los caracteres no son constantes, bien marcados, o se traslapan. Argythamnia neomexicana ha sido aceptada desde que fue descrita, pero Ingram (1970) notó que probablemente no era distinta de A. serrata y que ambas integran un complejo que requiere ser estudiado. Después de analizar unas 300 colectas representativas de la distribución de este complejo en México, se ha decidido tratar a A. neomexicana como sinónimo de A. serrata. Sin embargo, ha de destacarse que dentro de la especie hay tres grupos morfológica y geográficamente reconocibles:

(1) Argythamnia serrata sensu stricto está conformado por plantas perennes, postradas, hojas obovadas-espatuladas, conspicuamente aserradas, con indumento denso y tricomas de diferente grosor en el envés, flores pistiladas con sépalos menores de $3.5 \mathrm{~mm}$, no acrescentes en el fruto y semillas globosas suaves. Los ejemplares tipo de Ditaxis odontophylla, A. serrata y A. serrata var. magdalenae representan este grupo. Su distribución se concentra en el suroeste de Estados Unidos de América y noroeste de México.

(2) Un grupo de hierbas perennes, erectas, con indumento disperso de tricomas delgados y grosor homogéneo, rara vez glabras, reproductivas desde el primer año de vida, con hojas elípticas, aserruladas, flores pistiladas con sépalos acrescentes en el fruto, pétalos bien desarrollados y semillas globosas y estriadas. Su distribución se concentra en el suroeste de Estados Unidos de América y noroeste de México. El material tipo de A. californica, A. dressleriana (ver discusión abajo), A. gracilis y A. neomexicana es representativo de este grupo. Además se incluyen aquí las hierbas perennes, compactas, con hojas lanceoladas y ápice rostrado, aparentemente enteras por el indumento denso y estrigoso que cubre el margen aserrulado, que crecen en las islas y costas cercanas al Mar de Cortés. Steinmann y Felger (1997) notaron que las plantas con estas características probablemente representan un híbrido de A. neomexicana y A. serrata o un taxón no descrito.

(3) Argythamnia micrandra representa las hierbas anuales, con hojas elípticas y aserruladas, indumento de tricomas delgados y dispersos, flores pistiladas con sépalos acrescentes en el fruto, pétalos reducidos y semillas profunda y angulosamente reticuladas y estriadas. Croizat (1945) describió esta especie sin compararla con ninguna otra y sus diferencias con A. neomexicana no siempre son claras. Argythamnia micrandra forma un grupo claramente distinguible en la cuenca del Balsas, Veracruz, Chiapas y Guatemala. Pero en Chihuahua, Coahuila, Durango, Querétaro, Tamaulipas y San Luis Potosí se pueden encontrar hierbas perennes con flores estaminadas de pétalos reducidos y semillas estriadas y reticuladas, a veces angulosas que podrían determinarse 


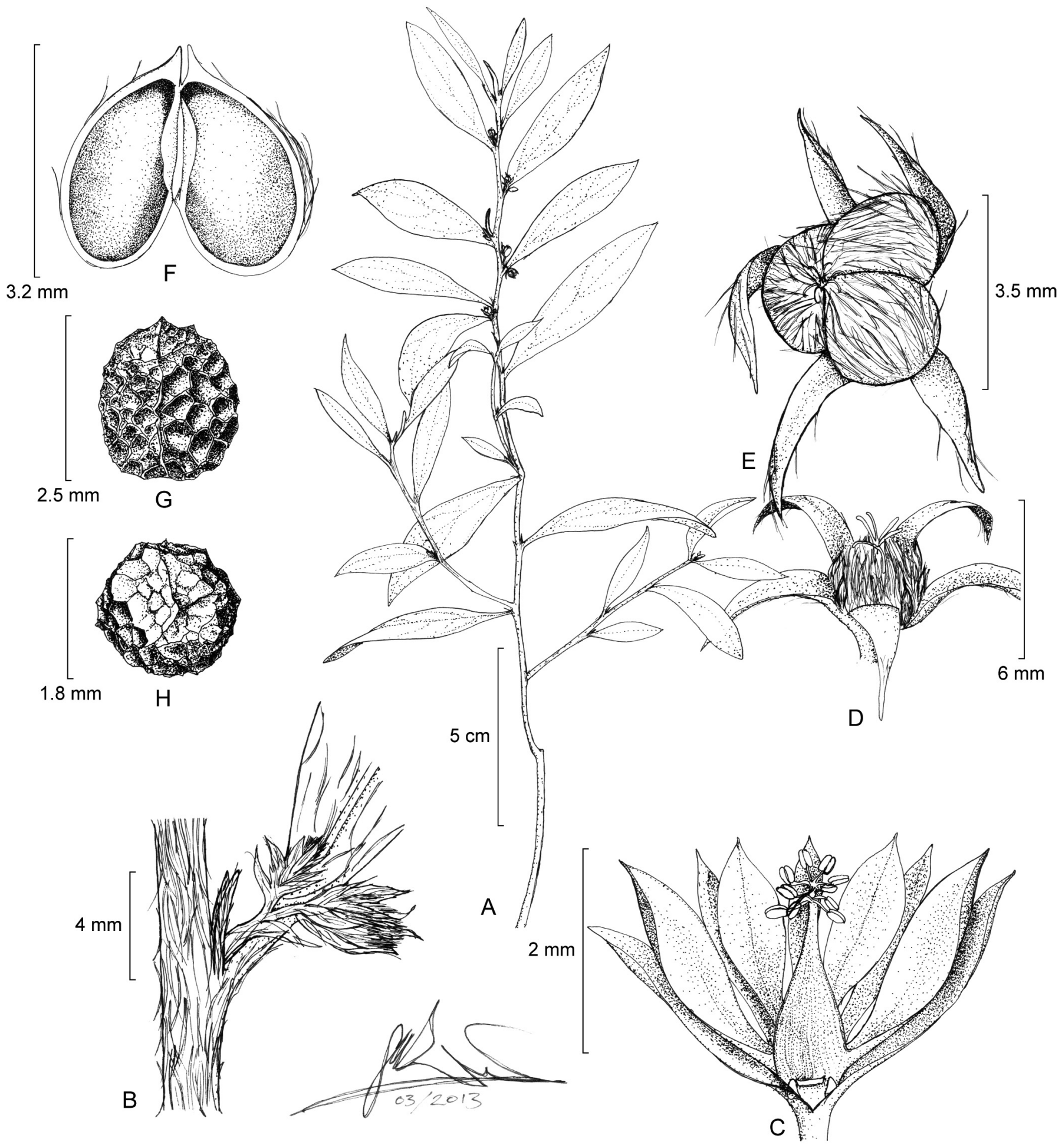

Figura 7. Argythamnia silviae Y.Ramírez-Amezcua y V.W.Steinm. A. Hábito. B. Detalle mostrando las estípulas y una inflorescencia joven. C. Flor estaminada con un pétalo removido. D. Flor pistilada. E. Fruto. F. Apariencia de un lóculo después de la dehiscencia. G. Semilla, vista dorsal. H. Semilla, vista apical. 
indistintamente como A. micrandra o como A. neomexicana. Al contemplar la distribución general del complejo, resulta claro el gradiente de variación en cuanto al tamaño de los pétalos de las flores estaminadas y la ornamentación de la semilla. El trabajo molecular realizado hasta ahora (Ramírez-Amezcua, 2011) no incluye estas entidades, y al igual que en otros complejos de especies, es deseable un estudio molecular que pudiera sustentar su reconocimiento a nivel jerárquico.

Brandegee (1906) propuso Argythamnia californica sin establecer sus afinidades. En 1995, Steinmann y Felger la reubicaron como variedad de A. serrata, que se distingue por carecer de indumento y al parecer no forma poblaciones; es decir, las plantas glabras siempre se encuentran con plantas pubescentes (Jon Rebman, com. pers.), como ocurre en el caso de las plantas glabras de A. humilis. Estas plantas glabras no se reconocen en este trabajo bajo ninguna categoría infraespecífica y se consideran parte de la variación de A. serrata. Cabe mencionar que el holotipo de A. californica pertenece a A. neomexicana y no a A. serrata s.s., como Steinmann y Felger pensaron.

Ingram (1953) describió Argythamnia dressleriana como una especie afín a A. serrata. El autor diferenció su nueva especie por tener flores pistiladas con sépalos ovados, flores estaminadas con pétalos de casi $1 \mathrm{~mm}$ de largo, ovados a elíptico-obovados, con tricomas en base de la cara externa, que se extienden hasta el ápice del pétalo. En contraste, caracterizó a $A$. serrata por tener flores pistiladas con sépalos lanceolados, flores estaminadas con pétalos de casi $3 \mathrm{~mm}$ de largo, oblanceolados, con tricomas dispersos en la cara externa, que pueden o no extenderse más allá del ápice del pétalo. Debido al poco conocimiento de la especie (derivado de la escasez de material herborizado) y a la problemática taxonómica en torno a A. serrata, fue reconocida como una especie válida y endémica de la zona de Tehuacán, Puebla. Antes de la revisión del género en México, A. dressleriana se conocía solamente del holotipo, un ejemplar con material escaso y semillas inmaduras, difícil de ubicar taxonómicamente. Ahora se conocen dos ejemplares más de la zona de Cuicatlán, Oaxaca, que corresponden a esta entidad [Cruz 2390 (ENCB); García, Salinas y Martínez 3326 (MEXU)]. Gracias a este material y al estudio del complejo que agrupa A. serrata, es posible determinar que los caracteres usados por Ingram no permiten distinguir claramente las dos especies, por lo que A. dressleriana se trata como sinónimo.

Algunos ejemplares presentan las características generales de Argyhtamnia serrata pero con algunas ligeras variaciones por lo que han sido etiquetados como A. aff. serrata (Torr.) Müll.Arg. Dos colectas de Sinaloa tienen estigmas inmaduros escasamente aplanados y flores estaminadas jóvenes con los pétalos adnados al andróforo [near San Blas, Rose, Standley y Russell 13246 (US); Topolobampo, Rose, Standley y Russell 13313 (NY, US)]. Otra colecta de Sonora presenta los estigmas aplanados y purpúreos, aunque en flo- res más jóvenes parecen rollizos [San Bernardo, Río Mayo, Lower Sonoran, arroyo, Gentry $1356(\mathrm{MICH})]$.

No cabe duda que sería muy provechoso investigar a fondo el complejo representado por Argythamnia serrata; un estudio filogeográfico a través de su rango de distribución podría respaldar el reconocimiento de taxa infraespecíficos y aportar información muy valiosa para relacionarla con la variación morfológica aquí detallada.

Material adicional examinado: MÉXICO. BAJA CALIFORNIA: San Luis González Bay, Johnston 3332 (CAS, UC); Isla Arroyo Las Palmas $1 \mathrm{~km} \mathrm{SE}$ of Rancho Los Gavilanes, Moran 25162 (ENCB, MICH, MO, US); Lagoon Head, Palmer 788 (F, GH, MEXU, NY, UC, US). BAJA CALIFORNIA SUR: Laguna de San Ignacio, Carter, Alexander y Kellog 2510 (DS, LL, MEXU, UC); Las Tinajas vicinity, in cerros E of Picachos de Santa Clara, Gentry 7578 (DS, GH, UC); between Santonio y Puerto de Bahía de los Muertos, Wiggins 5629 (CAS, DS, GH, MICH, NY, UC). CHIAPAS: Mpio. Acala, bluffs above presa La Angostura, 45 km from Tuxtla, Breedlove 37399 (DS); Mpio. La Trinitaria, road to Boquerón \& Ejido Mújica W of Mex. hwy. 190 at point $18 \mathrm{~km} \mathrm{SW}$ of La Trinitaria, Breedlove 42272 (DS). CHIHUAHUA: $14 \mathrm{~km} \mathrm{E}$ of Álamo Chapo Viejo on the road to Manuel Benavides, low hill at far SW end of Sierra Mulato, Chiang, Wendt y Johnston 9694d (LL, MEXU); $10-15$ mi SW of Nueva Casas Grandes, Correll y Johnston 21680 (LL, NY); entre Escalón y Caballo, carr. 49, cerca del borde con Ceballos Durango, Dwyer 14234 (MO). COAHUILA: $22 \mathrm{~km}$ ESE of La Cuesta del Plomo on the Muzquiz-Boquillas hwy. near the intersection of the hwy. to V. Acuña, N side of S. de la Encantada, Chiang, Wendt y Johnston 7544H (CAS, LL); San Lorenzo de la Laguna, $70 \mathrm{mi}$ al SW de Parras, Palmer 1250 (GH, NY, US); Valle del Río Grande, cerca de Díaz, Pringle 9022 (ENCB, DS, F, GH, MEXU, MO, US). COLIMA: along hwy. MEX 49, $9 \mathrm{~km}$ by road NE of Río Nazas bridge, ca. $10 \mathrm{~km} \mathrm{~W}$ of Ciudad Lerdo, Diggs y Nee 3128 (F, NY, XAL); Ceballos-Mohovano de Lilas, Tlahualilo de Zaragoza, Hinton et al. 24735 (MEXU, TEX); ca. $20 \mathrm{~km} \mathrm{NW}$ of Cuencamé, McVaugh 23619 (MICH). GUANAJUATO: 17 km NNW de San Miguel de Allende, sobre la carretera a Dolores Hidalgo, Rzedowski 47134 (IEB); Atareja, cerro Mangas Cuatas, Ventura y López 8948 (IEB). GUERRERO: Mpio. Iguala, Iguala, Almazan 56 (ENCB, UAGC); Coyuca, Pungarabato, Hinton et al. 5438 (F, GH, NY); Mpio. Atoyac, $4 \mathrm{~km}$ al noreste de Atoyac, sobre la carretera a El Paraíso, RamírezAmezcua, Steinmann y Porter 871 (IEB). MICHOACÁN: Mpio. Apatzingán, pedregal a unos $3 \mathrm{~km}$ al NE de Apatzingán por la carretera MEX 120, Ramírez-Amezcua y Steinmann 390 (IEB); Mpio. Gabriel Zamora, along the autopista Uruapan-Lázaro Cárdenas, $12.5 \mathrm{~km} \mathrm{~N}$ of the exit for Santa Casilda, Steinmann 1709 (IBUG, IEB; NY, XAL); Mpio. La Huacana, sobre MEX 37 (libre), $5.2 \mathrm{~km}$ al sureste de 
Cupuancillo, arriba de la carretera en la cara sureste de la Mesa de La Lima; Steinmann y Ramírez-Amezcua 5526 (IEB). NUEVO LEÓN: Galeana, on W side of MEX 57 in sharp turn, $4.3 \mathrm{~km} \mathrm{~S}$ of road to Puerto México, ca. $4.5 \mathrm{~km}$ (air) E of El Prado, $10 \mathrm{~km} \mathrm{~S}$ of Coahulia state line, ca $20 \mathrm{~km}$ NW of San Rafael, cerro atravesado, Huachichil, Bridges $y$ Woodruff 13109 (MEXU, TEX); at the Tamaulipas state line on the Victoria-Linares hwy., Johnston y Crutchfield $5829 D$ (TEX); Monterrey, Obispado, Lacás 106 (F); 23 mi N of Sabinas Hidalgo, Webster y Barkley 14581 (LL, US). OAXACA: $2.5 \mathrm{~km}$ al SSW de Tepelmeme de Morelos, Cruz 2390 (ENCB); $12 \mathrm{~km} \mathrm{NE}$ of the city of Tehuantepec, along the Pan-American hwy. (routes 185 \&190), King 399 (ENCB, MEXU, MICH, TEX, US); Distr. Tehuantepec, subida al cerro Guiengola por la ladera $\mathrm{S}$, donde está la fábrica de cal, Torres, Torres y Martínez 621 (MEXU); Mpio. San Carlos Yautepec, above the Río Grande, $10 \mathrm{mi}$ NW of El Camarón, Webster y Armbruster 21051 (MEXU, UC). PUEBLA: Mpio. San José Miahuatlán, Cerro Tepetroje, $6 \mathrm{~km}$ al O de Axuxco, García, Salinas y Martínez 3326 (MEXU). QUERÉTARO: $3 \mathrm{~km}$ al S de Cadereyta, Rzedowski 49679 (IEB); $4 \mathrm{~km}$ south of Vizarrón de Montes, Steinmann $705 \mathrm{~b}$ (IEB); Mpio. San Joaquín, Cañada La Culebra, 3 km al NE de La Tinaja, Zamudio y Pérez-Cálix 9390 (IEB, MEXU). SAN LUIS POTOSÍ: Estación de microondas "Pastoriza" 22 $\mathrm{km} \mathrm{S}$ of Matehuala, Johnston 11109B (LL); km 20 carretera San Luis-Río Verde, Rzedowski 6175 (ENCB). SINALOA: Mocorito, aprox. $3 \mathrm{~km}$ al E de Caimanero, Bojórquez 578 (MEXU); Río Fuerte, Gentry 946M (MICH, US); $17 \mathrm{mi}$ al N de Los Mochis, Webster et al. 15626 (UC). SONORA: Sierra del Rosario, Gran Desierto, south facing slope of canyon at $\mathrm{S}$ side of main mountain mass, Felger 75-16 (ENCB, MEXU); $4 \mathrm{mi}$ al W de Caborca, Keck 4038 (DS, GH, UC, US); Hermosillo, Bahía Kino, Steinmann, Reina y Van Devender 908 (IEB); $7 \mathrm{mi}$ al E de la Colonia Morelos camino a la Colonia Oaxaca, White 4428 (GH, MICH). TAMAULIPAS: $11 \mathrm{mi}$ from Santander Jiménez on the road to Padilla, Johnston y Graham 4396 (MICH, TEX); Cercanías de Victoria, Palmer 534 (US); 34 mi S of Nuevo Laredo, Rollins y Tryon 5808 (GH, LL); near San Vicente, Jaumave, Von Rozynski 230 (F). VERACRUZ: Mpio. Dos Ríos, Cerro Gordo, Ventura 4440 (ENCB); Mpio. Actopan, Guajillo, Ventura 7790 (ENCB, IBUG, MEXU, TEX). ZACATECAS: Mpio. Cañitas de Felipe Pescador, km 45 carretera Villa de Coss-Cañitas de Felipe Pescador, Balleza y Adame 13563 (“UAZ”); Campo Experimental Noria de Guadalupe, $33 \mathrm{~km}$ al S de Concepción del Oro (carr. 54), Villarreal y Vázquez 6151 (IEB).

Argythamnia silviae Y.Ramírez-Amezcua et V.W.Steinm. sp. nov. (Figura 7).

Tipo: MÉXICO. OAXACA: Distrito Tehuantepec, Mpio. San Pedro Huamelula, Río Seco, 1559'26.2'N, 9545'26.8”'W, R. García Sosa 395 (holotipo IEB; isotipo SERO).
Perennial herb to $1 \mathrm{~m}$ tall, monoecious, stems erect, strigulose. Stipules deciduous, subulate or linear, 2-4.3 mm long. Petiole 2-5 mm long. Leaves elliptic, 1.7-1.0 cm long, 0.8$3.3 \mathrm{~cm}$ wide, base attenuate, apex acute, margin serrulate. Inflorescences $5-10 \mathrm{~mm}$ long, with a pistillate flower at the base and 4-7 staminate flowers in the distal portion; bracts elliptic, $1.5-2.5 \mathrm{~mm}$ long, 0.6-0.8 mm wide. Staminate flowers with pedicels $0.2-0.3 \mathrm{~mm}$ long; sepals 5 , lanceolate, 2-3.2 mm long, 0.4-0.5 mm wide, apex acute, margin entire to undulate; petals 5, elliptic, 2-3 mm long, 0.8-1.2 mm wide, base and apex acute, adnate to the staminal column, blue, purple, pink or green-yellow when young, margin entire to erose, stamens 10 , arranged in two whorls of 5, staminal column swollen at the base, $1.5-1.7 \mathrm{~mm}$ long, $0.4-0.7 \mathrm{~mm}$ wide, free portion of the filiments $0.3-0.5 \mathrm{~mm}$ long. Pistillate flowers with pedicels 1-1.2 mm long; sepals 5, lanceolate, 6$9 \mathrm{~mm}$ long, 0.8-1.4 mm wide, apex acute, margin serrulate; petals 5, elliptic, 1.4-2.1 mm long, 0.5-1 mm wide, base and apex acute, white to yellowish, margin ciliate; ovary hispidulose, styles 1.2-1.7 mm long, free from 0.9-1.2 mm; stigmas terete. Capsules 2.5-3.5 mm long, 4-5 mm wide, hispidulose, purple. Seeds globose, 2-2.5 mm long, 1.8-2.3 mm wide, base rounded, apex apiculate, surface deeply alveolate.

Hierba perenne de hasta $1 \mathrm{~m}$ de alto, monoica, tallos erectos, estrigulosos, ramillas con ligeras líneas verticales, estrigosas o estrigulosas, verdes. Hojas con estípulas caedizas, subuladas o lineares, de 2 a $4.3 \mathrm{~mm}$ de largo, estrigulosas; pecíolo de 2 a $5 \mathrm{~mm}$ de largo, indumento igual al de las ramillas; lámina elíptica, de 1.7 a $10 \mathrm{~cm}$ de largo, de 0.8 a $3.3 \mathrm{~cm}$ de ancho, verde o con tonalidades doradas por el indumento, con 3 nervaduras suprabasales, estrigosa o estrigulosa; base atenuada; ápice agudo; margen aserrulado con dientes papilados. Inflorescencias de 5 a $10 \mathrm{~mm}$ de largo, con una flor pistilada en la base y de 4 a 7 flores estaminadas en la parte distal; brácteas elípticas, de 1.5 a $2.5 \mathrm{~mm}$ de largo, de 0.6 a $0.8 \mathrm{~mm}$ de ancho, estrigulosas o glabrescentes, ápice agudo; margen eroso. Flores estaminadas sobre pedicelos glabrescentes de 0.2 a $0.3 \mathrm{~mm}$ de largo; sépalos 5 , lanceolados, de 2 a $3.2 \mathrm{~mm}$ de largo, de 0.4 a $0.5 \mathrm{~mm}$ de ancho, ápice agudo, margen entero a ondulado, externamente estrigulosos, internamente glabros; pétalos 5, elípticos, de 2 a $3 \mathrm{~mm}$ de largo, de 0.8 a $1.2 \mathrm{~mm}$ de ancho, base aguda, ápice agudo, adnados a la columna estaminal, azules, purpúreos, rosados o verde-amarillentos cuando jóvenes, margen entero o eroso, glabros en ambas caras; estambres 10 , dispuestos en 2 verticilos de 5 cada uno, columna estaminal purpúrea o amarillenta, engrosada en la base, de 1.5 a 1.7 $\mathrm{mm}$ de largo, de 0.4 a $0.7 \mathrm{~mm}$ de ancho, la parte libre del filamento de 0.3 a $0.5 \mathrm{~mm}$ de largo, estaminodios ausentes, solamente una callosidad apical de $0.1 \mathrm{~mm}$ de largo; glándulas ovadas, de 0.4 a $0.5 \mathrm{~mm}$ de largo, de 0.2 a $0.4 \mathrm{~mm}$ de ancho, glabras, amarillentas o purpúreas, ápice agudo. Flores pistiladas sobre pedicelos estrigulosos o glabrescentes 
de 1 a $1.2 \mathrm{~mm}$ de largo; sépalos 5 , lanceolados, de 6 a $9 \mathrm{~mm}$ de largo, de 0.8 a $1.4 \mathrm{~mm}$ de ancho, ápice agudo, margen aserrulado, externamente estrigosos a estrigulosos, internamente glabros o estrigulosos; pétalos 5, elípticos, de 1.4 a $2.1 \mathrm{~mm}$ de largo, de 0.5 a $1 \mathrm{~mm}$ de ancho, base aguda, ápice agudo, blanquecinos o amarillentos, margen ciliado, externamente estrigulosos, internamente glabros; ovario hispiduloso, estilos con tricomas agregados en un mechón al centro, de 1.2 a $1.7 \mathrm{~mm}$ de largo, libres de 0.9 a $1.2 \mathrm{~mm}$; estigmas rollizos, amarillentos; glándulas oblatas, de 0.3 a $0.5 \mathrm{~mm}$ de largo, de 0.2 a $0.7 \mathrm{~mm}$ de ancho, glabras, amarillentas o purpúreas, ápice obtuso. Cápsulas de 2.5 a $3.5 \mathrm{~mm}$ de largo, de 4 a $5 \mathrm{~mm}$ de ancho, hispidulosas, purpúreas. Semillas globosas, de 2 a $2.5 \mathrm{~mm}$ de largo, de 1.8 a $2.3 \mathrm{~mm}$ de ancho, base redondeada, ápice apiculado, pardo-grisáceas con azul, carúncula ausente, rafe inconspicuo, superficie profundamente alveolada.

Distribución y ecología: Endémica de México y conocida solamente de Oaxaca (Figura 4), crece en bosque tropical caducifolio a $290 \mathrm{~m}$. Colectada en octubre con flores y frutos inmaduros.

Etimología: Esta especie se nombra en honor a la Botánica Silvia Salas Elorsa, especialista en la flora de Oaxaca, quien colectó esta especie por primera vez y proporcionó el material para describirla.

Argythamnia silviae es afín a A. serrata. Presenta indumento escaso y estípulas filiformes y notorias de hasta 3.5 $\mathrm{mm}$ de largo; las flores estaminadas maduras tienen los pétalos azules, purpúreos o rosados, libres de la columna estaminal, misma que se engrosa notoriamente hacia la base (de 0.4 a $0.7 \mathrm{~mm}$ de ancho). Al igual que en $A$. serrata (pro parte), las flores pistiladas tienen sépalos acrescentes en el fruto, pétalos femeninos reducidos y estigmas rollizos, así como flores estaminadas con sépalos lanceolados; sin embargo, en A. silviae éstos son más largos y relativamente más angostos que en A. serrata ( 2 a $3.2 \mathrm{~mm}$ de largo y 0.4 a $0.5 \mathrm{~mm}$ de ancho vs. 0.9 a $2.5 \mathrm{~mm}$ de largo y 0.4 a $1.4 \mathrm{~mm}$ de ancho, respectivamente). Además, A. serrata generalmente presenta indumento denso, estípulas inconspicuas (menos de $2.3 \mathrm{~mm}$ de largo) y flores estaminadas maduras con los pétalos amarillentos o blancos, (rara vez rosados en la parte media) y la columna estaminal no se engrosa hacia la base.

Ejemplar adicional examinado: MÉXICO. OAXACA: Distrito Tehuantepec, Mpio. San Pedro Huamelula, desviación a Guadalupe Victoria, $14.3 \mathrm{~km}$ por la brecha, Salas, Elorsa y Sánchez 3496 (MEXU, SERO).

Argythamnia simulans J.W.Ingram, Bull. Torrey Bot. Club 84(6):421(-423). 1957. Ditaxis simulans (J.W.Ingram) Ra-
dcl.-Sm. \& Govaerts, Kew Bull. 52:479. 1997. Tipo: Estados Unidos de América, Texas, frequent in shady places on limestone hill, 1/2 mi SW of Kerr County, 29 abr. 1946, V.L. Cory 51850 [holotipo UC (no visto); isotipo US].

Hierba perenne o subarbusto de hasta $60 \mathrm{~cm}$, monoico (rara vez dioico), tallos varios saliendo de la base, con tonalidades purpúreas, ramillas con líneas verticales, estrigosas. Hojas con estípulas caedizas, elípticas, de 0.3 a $0.4 \mathrm{~mm}$ de largo, estrigosas; pecíolo ausente; lámina ovada a elíptica, de 2 a $7.5 \mathrm{~cm}$ de largo, de 0.6 a $3.8 \mathrm{~cm}$ de ancho, verde, frecuentemente con tonalidades purpúreas, con tres nervaduras basales, estrigulosa en ambas caras, con los tricomas agregados en las nervaduras y los márgenes; base atenuada, obtusa o redondeada; ápice agudo; margen escasamente aserrulado a entero. Inflorescencias de 3.5 a $5 \mathrm{~cm}$ de largo, con una flor pistilada en la base, a veces 2 y de 2 a 8 flores estaminadas en la parte distal; brácteas elípticas, de 1a $1.5 \mathrm{~mm}$ de largo, de 0.5 a $0.8 \mathrm{~mm}$ de ancho, estrigulosas, margen entero a ondulado. Flores estaminadas sobre pedicelos estrigulosos de 0.8 a $1 \mathrm{~mm}$ de largo; sépalos 5 , angostamente elípticos, de 4 a $5.3 \mathrm{~mm}$ de largo, de 0.9 a $1.6 \mathrm{~mm}$ de ancho, ápice agudo, margen entero, externamente estrigulosos, internamente glabros; pétalos 5, elípticos, de 2.7 a 4 mm de largo, de 1.2 a $1.5 \mathrm{~mm}$ de ancho, base atenuada, ápice apiculado, adnados a la columna estaminal, amarillentos, margen entero, glabros en ambas caras; estambres 8, dispuestos en 2 verticilos, el proximal de 5 y el apical de 3 estambres, columna estaminal de 1.5 a $2 \mathrm{~mm}$ de largo, de $0.5 \mathrm{~mm}$ de ancho, amarillenta o verdosa, la parte libre del filamento de 0.6 a $0.7 \mathrm{~mm}$ de largo, estaminodios ausentes; glándulas ovadas, de 0.5 a $0.8 \mathrm{~mm}$ de largo, de 0.3 a $0.6 \mathrm{~mm}$ de ancho, glabras, amarillentas, ápice agudo. Flores pistiladas sobre pedicelos estrigosos de 1.2 a $3 \mathrm{~mm}$ de largo; sépalos 5, angostamente elípticos, de 6 a $9 \mathrm{~mm}$ de largo, de 1.7 a $2.7 \mathrm{~mm}$ de ancho, ápice agudo, margen entero, externamente estrigulosos, con los tricomas agregados en el margen, internamente glabros; pétalos 5, ausentes (o cuando presentes puntiformes o lanceolados); ovario estrigoso, estilos estrigulosos, de 1.5 a $2.1 \mathrm{~mm}$ de largo, libres de 1 a $1.2 \mathrm{~mm}$; estigmas aplanados, amarillentos; glándulas ovadas, de 0.3 a $0.4 \mathrm{~mm}$ de largo, de 0.5 a $0.6 \mathrm{~mm}$ de ancho glabras, amarillentas, ápice truncado o emarginado. Cápsulas hispidulosas, de 3.5 a $7 \mathrm{~mm}$ de largo, de $4.2 \mathrm{a}$ $7.5 \mathrm{~mm}$ de ancho, purpúreas. Semillas globosas, de 4 a 4.2 $\mathrm{mm}$ de largo, de 3.5 a $3.8 \mathrm{~mm}$ de ancho, base redondeada o tuncada, ápice apiculado, grises, carúncula ausente, rafe evidente, superficie con excrecencias ligeras e irregulares.

Distribución y ecología: En México se conoce de una colecta de Coahuila (Figura 6); en Estados Unidos de América de la parte centro-sur de Texas. Crece en bosque de pino-encino, en suelos arenosos, rocosos y calizos, probablemente entre 1,800 y $1,900 \mathrm{~m}$. Se ha colectado con flor y fruto en mayo. 
Ejemplar adicional examinado: MÉXICO. COAHUILA: Mpio. Villa Acuña. Serranías del Burro, Rancho El Bonito, in canyon La Pantera, Riskind 2370 (MEXU, TEX, UC).

\section{Especies dudosas y material excluido}

Argythamnia claryana Jeps., Fl. Calif. 2:419(-420). 1936. Ditaxis claryana (Jeps.) G.L.Webster in V.W.Steinm. y Felger, Aliso, 16(1):25. 1997. Tipo: Estados Unidos de América, California, foot of Santa Rosa Mts., ca. $10 \mathrm{mi} \mathrm{W}$ of Coachela and $3 \mathrm{mi} \mathrm{W}$ of Coral Reef Ranch, ca. $300 \mathrm{ft}$ (91 m), 24 oct. 1936, M. D. Clary 1707 [holotipo JEPS; isotipos A, GH, RSA (no visto)].

Se conoce del suroeste de Estados Unidos de América. Crece en llanuras desérticas y suelos pedregosos, en altitudes cercanas a los $100 \mathrm{~m}$. Colectada con flor y fruto en abril, noviembre y octubre. Argythamnia claryana es una especie afín a A. adenophora, incluso han sido tratadas como sinónimos. Se distingue por tener tricomas malpigiáceos en toda la planta y glándulas delgadas sin un estípite claro en los márgenes de hojas, estípulas y sépalos femeninos. En contraste, A. adenophora tiene tricomas malpigiáceos exclusivamente en ovarios y cápsulas y las glándulas claramente estipitadas en los márgenes de hojas, estípulas y sépalos femeninos. Argythamnia claryana ha sido citada para México por Martínez et al. (2002) y por Steinmann (2002). Además, es probable que la referencia de A. adenophora para Baja California (Wiggins, 1980) refiera a A. claryana, ya que dicho autor la consideró sinónimo de la primera. A pesar de que no se conoce ningún ejemplar que respalde su presencia en el país, es probable que ocurra en México dada la cercanía de algunas poblaciones en el sureste de California y suroeste de Arizona.

Material adicional examinado: E.U.A.: ARIZONA, Clear Lake, off Colorado River, sec. 33, Wheeler 7674 (IEB, RSA); Yuma, SE 1/4 Sec. 33, T4S, R15W, G\&SRM Kof a Game Range, Dodson 36 (ENCB). CALIFORNIA, Chocolate Mountains, Ferguson Wash, Wheeler 7673 (IEB, RSA).

\section{Argythamnia aff. serrata (Torr.) Müll.Arg.}

Las colectas de la península de Yucatán tienen flores pistiladas con pétalos reducidos, estigmas rollizos y semillas angulosamente reticuladas como Argythamnia serrata; sin embargo, poseen flores estaminadas con pétalos adnados al andróforo. No es claro si estas variaciones representan taxones independientes y por el momento no ha sido posible determinarlas con certeza ni darles un estatus de taxa no descrito.

El material referido se enlista enseguida: CAMPECHE: Mpio. Chalakmul, $2 \mathrm{~km}$ al W de Plan de San Luis en el km 132 de la carretera Escárcega-Chetumal, Martínez et al. 30012-4 (FCME); Mpio. Hecelchacán, carretera que va de
Dzitnup a Caumpich y entronca con MEX 261, aprox. $7 \mathrm{~km}$ de Dzitnup, Ramírez-Amezcua et al. 2011 (IEB). YUCATÁN: Chichankanab [Quintana Roo, Mpio José María Morelos, "Chichankanab", sin fecha, Gaumer 1466 (F); Km 8 carretera San Diego-Xtampú, Dzemul, Trejo, May y Castillo 502 (F).

\section{Agradecimientos}

Los autores agradecen profundamente al Instituto de Ecología, A.C., Centro Regional del Bajío y a su personal, así como el apoyo financiero (cuenta número 20006) del Consejo Nacional de Ciencia y Tecnología y de la Comisión Nacional para el Conocimiento y Uso de la Biodiversidad. A los curadores de los herbarios A, CAS, CIMI, CICY, DS, ENCB, F, FCME, GH, HCIB, HUAA, IBUG, IEB, LL, MEXU, MICH, MO, NY, SERO, UAGC, UAMIZ, "UAZ", UC, US, XAL y ZEA, por permitir el acceso a sus colecciones. Gracias a Mollie Harker, Raymundo Ramírez, Eleazar Carranza y Jacqueline Reynoso, quienes contribuyeron a mejorar la calidad de este trabajo; a Antonio Machuca, Ana Rocha, Ignacio García, Sergio Zamudio, Mark Porter, Mark Olson y Manuel Ramírez por ayuda en campo. A Emily Lott, Silvia Salas y Arturo Sánchez por el material de Oaxaca y a Jon Rebman, Rosalinda Medina y Silvia Hernández por su información sobre localidades. A Damián Piña por su ayuda con los mapas y la figura y a Manuel Ramírez por preparar las ilustraciones. Agradecemos a Angélica Cervantes Maldonado y un revisor anónimo por sus comentarios para mejorar el manuscrito.

\section{Literatura citada}

Bentham G. 1844. Serophyton. The Botany of the Voyage of H.M.S. Sulphur 52-53.

Bentham G. 1880. Argythamnia. Genera Plantarum 3:303.

Brandegee T.S. 1906. Argythamnia californica. Zoe 5:230.

Brandegee T.S. 1908. Argythamnia gracilis. Zoe 5:242-243.

Burger W. y Huft M. 1995. Flora Costaricensis, Euphorbiaceae. Fieldiana 36(113):1-169.

Calderón de Rzedowski G. 2001. Argythamnia. En: Rzedowski G.C. de, Rzedowski J. y colaboradores. Flora Fanerogámica del Valle de México. 2a. Ed., pp 352, Instituto de Ecología, A.C., Comisión para el Conocimiento y Uso de la Biodiversidad, Pátzcuaro.

Croizat L. 1945. Argythamnia. En: New or critical Euphorbiaceae from the Americas. Journal of the Arnold Arboretum 26:191.

Diggs G.M.Jr., Lipscomb B.L. y O’Kennon R.J. 1999. Shiners and Mahler's: Illustrated Flora of North Central Texas. Botanical Research Institute and Austin College for Enviromental Studies of Texas, Fort Worth.

Eastwood A. 1929. Ditaxis serrata var. magdalenae. Proceedings of the California Academy of Sciences Series 4 18:479.

Engelmann G. y Gray A. 1845. Aphora humilis. Plantae Lindheimerianae 1:54.

Govaerts R., Frodin D.G. y Radcliffe-Smith A. 2000. World Checklist and Bibliography of Euphorbiaceae (and Pandaceae). The Royal Botanical Gardens Kew, London. 
Gray A. 1870. Argythamnia adenophora. Proceedings of the American Academy of Arts and Sciences 8:294.

Greenman J.M. 1898. Argythamnia. Proceedings of the American Academy of Arts and Sciences 33:478.

Greenman J.M. 1905. Argythamnia. Spermatophytes from Mexico. Proceedings of the American Academy of Arts and Sciences 41:239.

Greuter W., McNeill J., Barrie F.R., Burdet H.M., Demoulin V., Filgeiras T.S., Nicholson D.H., Silva P.C., Skog J.E., Trehane P., Turland N.J. y Hawksworth D.L. 2002. Código Internacional de Nomenclatura Botánica, (código de Saint. Louis). Instituto de Botánica Darwinion y Missouri Botanical Press, Saint Louis.

Heller A.A. 1898. Catalogue of North American Plants North of Mexico, Exclusive of the Lower Cryptogams.

Heller A.A. 1912. New combinations IX. Muhlenbergia 8:60.

Henrickson J. y Johnston M.C. 1997. Argythamnia. En: Henrickson J. y Johnston M.C. Eds. A Flora of the Chihuahuan Desert Region, Vol. I., pp. 783-785. Los Angeles.

Ingram J. 1953. New species and new combinations in the genus Argythamnia. Bulletin of the Torrey Botanical Club 80:420423.

Ingram J.W. 1956. A sectional revision of Argythamnia subgenus Ditaxis (Euphorbiaceae). Ph. D. Dissertation. University of California, Berkeley. 115 pp.

Ingram J. 1957. New Names in Argythamnia subgenus Ditaxis. Bulletin of the Torrey Botanical Club 84:421-423.

Ingram J. 1964. Argythamnia guatemalensis and A. tinctoria (Euphorbiaceae). Brittonia 16:271-275.

Ingram J. 1967. A revisional study of Argythamnia subgenus Argythamnia (Euphorbiaceae). Gentes Herbarum 10:1-38.

Ingram J.W. 1970. Argythamnia. En: Correll D.S. y Johnston M.C. Eds. Manual of the Vascular Plants of Texas, pp. 939-942, Texas Research Foundation, Renner.

Ingram J. 1980a. The generic limits of Argythamnia (Euphorbiaceae) defined. Gentes Herbarum 11:427-436.

Ingram J. 1980b. A revision of Argythamnia subgenus Chiropetalum (Euphorbiaceae). Gentes Herbarum 11:437-468.

Jepson W.L. 1936. Argythamnia claryana. A Flora of California 2:419-420.

Johnston I.M. 1923. Ditaxis. Contributions from the Gray Herbarium of Harvard University 68:86-87.

Johnston I.M. 1924. Ditaxis. Proceedings of the California Academy of Sciences. Series 4 12:1062-1064.

Johnston M.C. y Warnock B.H. 1962. The four kinds of Argythamnia (Euphorbiaceae) in far western Texas. The Southwestern Naturalist 7:154-162.

Jussieu A. de. 1824. De Euphorbiacearum: Generibus medisque earumdem viribus tentamen. Paris.

Kiesling R. 2003. Ditaxis. En. Kiesling R. Flora de San Juan, República de Argentina, Vol. II, pp. 74-76, Vazquez Mazzini Editores, Buenos Aires.

Martin W.C. y Hutchins C.R. 1980. Ditaxis. En: Martin W.C. y Hutchins C.R. Eds. A Flora of New Mexico, Vol. I, pp. 11941196. J. Cramer, Hirschberg.

Martínez G.M., Jiménez R.J., Cruz D.R., Juárez A.E., García R., Cervantes A. y Mejía H.R. 2002. Los géneros de la familia Euphorbiaceae en México. Anales del Instituto de Biología de la Uiversidad Nacional Autónoma de México, Serie Botánica 73:155-281.

McGregor R.L. 1986. Argythamnia. En: Barkley T.M., Brooks
R.E., Schofield E.K. y McGregor R.L. Eds. Flora of the Great Plains, pp. 537-538, University Press of Kansas, Lawrence.

McVaugh R. 1995. Euphorbiacearum sertum Novo-Galicianarum revisarum. Contributions from the University of Michigan Herbarium 20:173-215.

Méndez-Robles M.D., Flores-Chavira C., Jaramillo-Flores M.E., Orózco-Ávila I. y Lugo-Cervantes E. 2004. Chemical composition and current distribution of "Azafrán de Bolita" (Ditaxis heterantha Zucc; Euphorbiaceae): a food pigment producing plant. Economic Botany 58:530-535.

Millspaugh C.F. 1889. Argythamnia. Proceedings of the California Academy of Sciences, Series 2 2:220-222.

Millspaugh C.F. 1896. Contribution II to the coastal and plain flora of Yucatan. Publications of the Field Columbian Museum. Botanical Series 1:278-339.

Müller A. 1865. Euphorbiaceae, Argythamnia. Linnaea 34:144151.

Müller A. 1866. Argythamnia. En: de Candolle, Prodromus 15:1891261, 1269-1286.

Nuttall T. 1837. Aphora. Transactions of the American Philosophical Society Held at Philadelphia for Promoting useful Knowledge 5:174.

O’Donell C.A. y Lourteig A. 1942. Chrozophorae argentinae. Lilloa 8:37-87.

Pax F. y Hoffmann K. 1912. Euphorbiaceae-Acalypheae-Chrozophorinae. En: Engler A. Ed. Das Pflanzenreich 57:1-142.

Pax F. y Hoffmann K. 1914. Euphorbiaceae-Acalypheae-Mercurialinae. En: Engler A. Ed. Das Pflanzenreich 63:1-473.

Pax F. y Hoffmann K. 1931. Ditaxis, Argythamnia and Chiropetalum. En: Engler A. y Prantl K. Eds. Die natürlichen Pflanzenfamilien 2nd ed., 19c: 93-96.

Punt W. 1962. Pollen morphology of the Euphorbiaceae with special reference to taxonomy. Wentia 7:1-116.

Radcliffe-Smith A. 2001. Genera Euphorbiacearum. The Board of Trustees, Royal Botanic Garden Kew, London.

Radcliffe-Smith A. y Govaerts R. 1997. New names and new combinations in the Euphorbiaceae-Acalyphoïdeae. Kew Bulletin 52:477-481.

Ramírez-Amezcua Y. 2007. Revisión taxonómica del género Ditaxis (Euphorbiaceae) en México. Tesis licenciatura, Centro Universitario de Ciencias Biológicas y Agropecuarias, Universidad de Guadalajara. Zapopan. 120 pp.

Ramírez-Amezcua Y. 2011. Relaciones filogenéticas en Argythamnia (Euphorbiaceae) sensu lato. Tesis maestría, Facultad de Biología, Universidad Michoacana de San Nicolás de Hidalgo, Morelia. 59 pp.

Rose J.N. 1895. Argythamnia manzanilloana. Contributions from the United States National Herbarium 1:357.

Rose J.N. y Standley P.C. 1912. Ditaxis. Plants from the Pinacate region. Contributions from the United States National Herbarium 16:12-13.

Standley P.C. y Steyermark J.A. 1949. Ditaxis. Flora of Guatemala. Fieldiana: Botany 24:87-88.

Steinmann V.W. y Felger R.S. 1995. New combinations for Euphorbia and Ditaxis (Euphorbiaceae) in northwestern Mexico and southwestern United States. Madroño 42:455-457.

Steinmann V.W. y Felger R.S. 1997. The Euphorbiaceae of Sonora, México. Aliso 16:1-71.

Steinmann V.W. 2002. Diversidad y endemismo de la familia Euphorbiaceae en México. Acta Botanica Mexicana 61:61-93. 
Torrey J. 1858. Aphora. Report on the United States and Mexican Boundary Survey 2:196-197.

Turner B.L. 2001. Biological status of Argythamnia laevis (Euphorbiaceae). Sida 19:621-622.

Webster G.L. 1967. The genera of Euphorbiaceae in the southeastern United States. Journal of the Arnold Arboretum 48:303430.

Webster G.L. 1993. Euphorbiaceae. En: Hickman J.C. Ed. The Jepson Manual, Higher Plants of California, pp. 572-573, University of California Press, Berkeley.

Webster G.L. 1994. Synopsis of the genera and suprageneric taxa of Euphorbiaceae. Annals of the Missouri Botanical Garden 81:33-144.

Wheeler L.C. 1960. Euphorbiaceae. En: Kearney T.H. y Peebles
R.H. Eds. Arizona Flora with Supplement, pp. 501-520; 10581059, University of California Press, Berkeley.

Wiggins I.L. 1964. Ditaxis. En: Shreve F. y Wiggins I. Eds. Vegetation and Flora of the Sonoran Desert, Vol. I, pp. 784-789, Stanford University Press, Palo Alto.

Wiggins I.L. 1980. Euphorbiaceae. En: Wiggins I.L. Ed. Flora of Baja California, pp. 112-135, Stanford University Press, Palo Alto.

Wolf S.J. 1988. George Engelmann type specimens in the Herbarium of the Missouri Botanical Garden. Annals of the Missouri Botanical Garden 75:1608-1636.

Zuccarini J.G. 1832. Ditaxis heterantha. Abhandlungen der Mathematisch-Physikalischen Classe der Königlich Bayerischen Akademie der Wissenschaften 1:290.

Recibido 13 de noviembre de 2012

Aceptado 22 de abril de 2013 